\title{
ISSN 2317-3009
}

\section{Archives of Health Investigation}

Official Journal of the

I Congresso Médico-Acadêmico UFMS - CPTL

Três Lagoas - MS, Brasil

I COMAC 

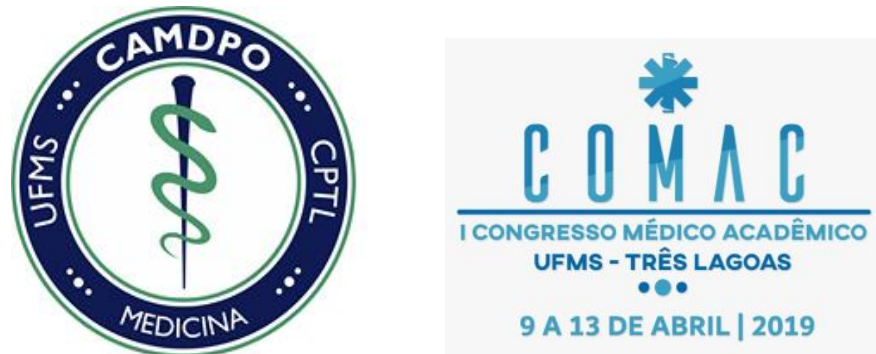

Coordenador Geral

Carlos Eduardo Macedo

Coordenadora Docente

Julie Massayo Maeda Oda

Coordenadora Discente

Vivielle Veloso de Moura Fé

Comissões Organizadoras I COMAC

Comissão Científica

Coordenadora Docente

Danielle Cristina Tonello Pequito

Coordenadoras Discentes

Rithelle Agledia Sampaio

Vivian Magalhães Domingues

Membros

Luís Gustavo Carvalho Barcellos

Renata Campos de Pieri

Daniella Muniz Martins

Comissão de Trabalho Científico

Coordenadora Docente

Bruna Moretti Luchesi

Coordenadora Discente

Lorena Batista

Membros

Ana Carolina Figueredo Vicente

Mirian Daiane de Oliveira

André Gustavo de Lima Godas

Thalyta Nogueira

Comissão de Cerimonial e Mídias Sociais

Coordenadora Docente

Priscila Balderrama

Coordenadores Discentes

Mariana Pittarelli de Souza

Samuel Braatz Couto

Membros

Marisa Oliveira Prado Santos Alyce da Silva Albuquerque Mariana Pittarelli de Souza

Vitor Pereira Machado

Luís Guilherme Fernandes Costa Lima Roselainy Fernanda Veiga 

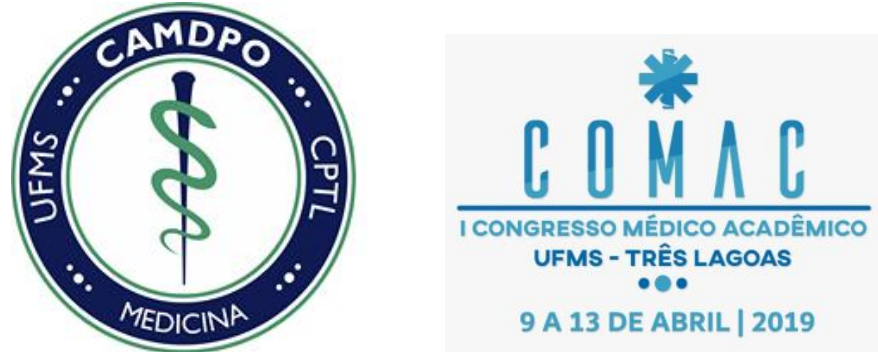

Comissão de Coffe Break e Patrocínio

Coordenadoras Discentes Stella Bianchini Borges

Eduarda Siqueira Cesário Membros

Natalia Santana Ferrareto Amanda Soares Pimenta Letícia Costa Coelho Bárbara Garcia Munhoz Isabella Rezende Santos

\section{Comissão de Inscrição}

Coordenadora Discente

Ana Carolina Gomes Furtado

Membros

Fernando Suguimoto Gabriela dos Reis Gomes Caroline Gabriela Xavier Ferreira Mariana Ferreira Carrijo Rusllan Ribeiro de Paiva Ferreira

Tesouraria Bruna Tiemi Minomi Suelen Scher 

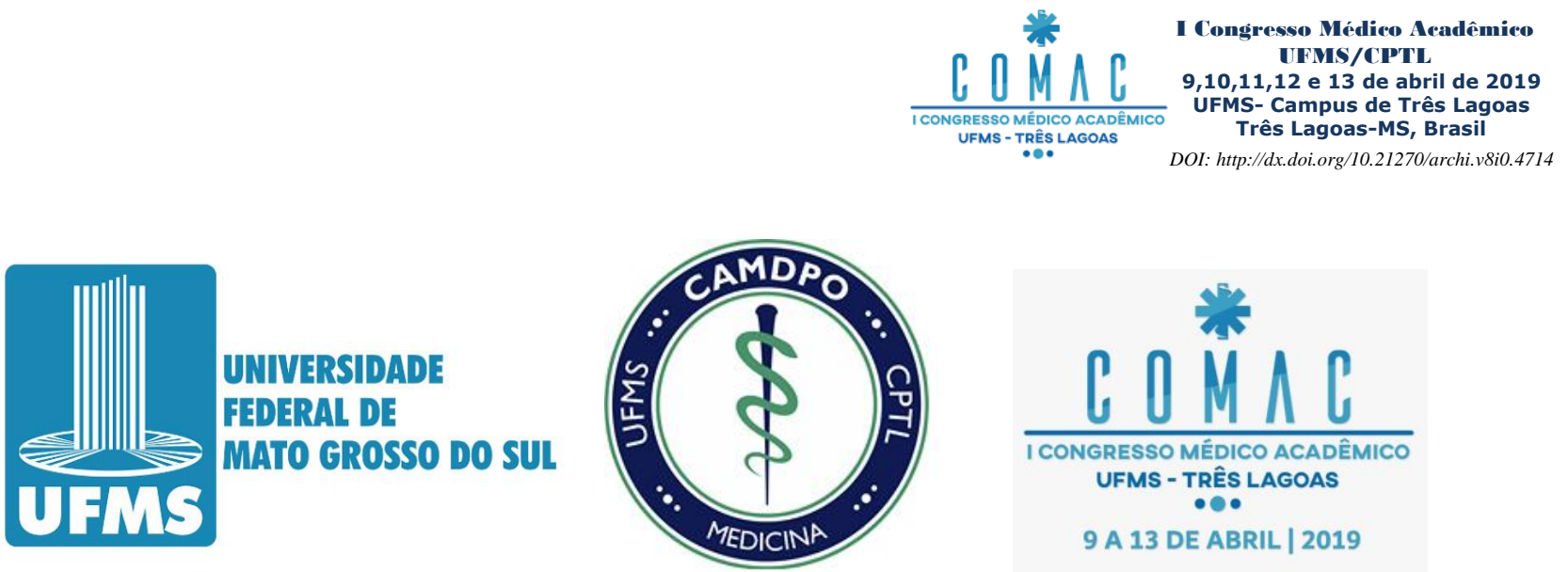

\section{Caro Leitor(a)}

O I Congresso Médico Acadêmico (COMAC) foi planejado e organizado pelo Centro Acadêmico de Medicina Dercir Pedro de Oliveira (CAMDPO) da Universidade Federal do Mato Grosso do Sul, campus de Três Lagoas. O congresso teve como objetivo principal promover uma semana rica em atividades capazes de expandir e atualizar o conhecimento em assuntos relevantes da área da saúde. $O$ período contou com a presença de figuras ilustres nas seguintes áreas: Pediatria, Oncologia, Endocrinologia, Gastroenterologia, Medicina Intensiva e Cardiologia. Além de palestras, a programação contou com mesas redondas, workshops e apresentação de trabalhos científicos.

$O$ 2nd International Workshop of Medicine, com o tema "CIRURGIA CARDÍACA E COMPLICAÇÕES NA SÍNDROME CORONARIANA AGUDA” trouxe-nos o nosso convidado internacional o Dr Rafael Otto Schneidewind, teuto-brasileiro, com residência em Cirurgia Cardiovascular na Alemanha (Hospital Herzzentrum Wuppertal) e especialização em Assistência Circulatória Mecânica (Ventrículo Artificial e ECMO) pela Universitäts Klinikum Freiburg.

O I Congresso Médico Acadêmico proporcionou, assim, o incentivo à pesquisa e ao intercâmbio de conhecimentos.

A Comissão Organizadora agradece a presença de todos que estiveram neste evento de grande sucesso. 


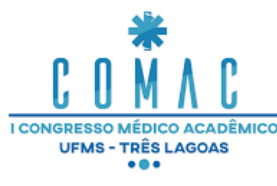
I Congresso Médico Acadêmico
UFMS/CPTL

9,10,11,12 e 13 de abril de 2019 UFMS- Campus de Três Lagoas Três Lagoas-MS, Brasil

DOI: http://dx.doi.org/10.21270/archi.v8i0.4714
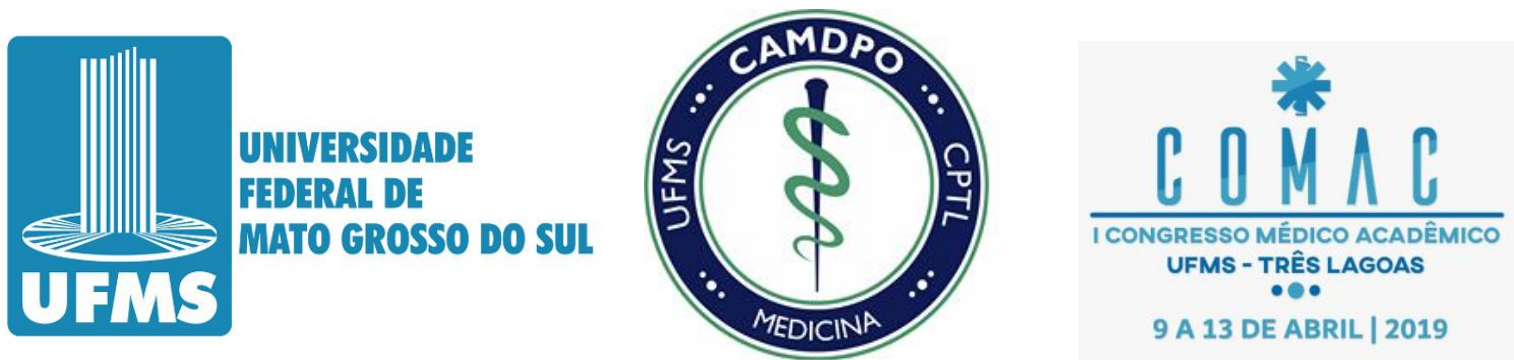

09/04 - CERIMÔNIA DE ABERTURA E PEDIATRIA

Coordenadora Docente: Dra. Ana Karina Soccheta Barros de Figueiredo

Coordenadora Discente: Vivian Magalhães

Cerimônia de abertura

Apresentação cultural (Profa. Kaelly Saraiva)

Palestra I: DIABETES TIPO I: O QUE HÁ DE NOVO? - Dr. Thiago Santos Hirose

Palestra II: LEUCEMIA E LINFOMAS EM CRIANÇAS - Dra. Dábada Canuto

Palestra III: DOENÇAS ALÉRGICAS NO CONSULTÓRIO PEDIÁTRICO - Dr. Antonio Carlos de Oliveira Biel

10/04 - ENDOCRINOLOGIA

Coordenador Docente: Drạ. Helena Nicolielo

Coordenador Discente: Renata Prieri

Apresentação cultural (Cia de Teatro AGSOL Girassol)

Palestra I: AVALIAÇÃO NUTRICIONAL POR ANTROPOMETRIA E COMPOSIÇÃO CORPORAL: BASES TEÓRICAS E DIFERENÇAS ENTRE MÉTODOS -

Drä. Patricia Pugliese

Palestra II: TRANSTORNO DE COMPULSÃO ALIMENTAR - Dr. Éder Caloi

Palestra III: MANEJO DA OBESIDADE NO TRATAMENTO DO DIABETES TIPO II - Drä. Clicia Moura Fé

MESA REDONDA - Tema: EVIDÊNCIAS EM DIETAS POPULARES (Dieta Low Carb, Jejum Intermitente, Dieta Cetogênica) - Palestrantes: Dr ${ }^{\text {a }}$ -

Helena Nicolielo, Drạ. Patricia Pugliese, Dr. Éder Caloi, Drä.Clicia Moura Fé.

11/04 - WORKSHOP - BLOCO VIII UNIDADE II UFMS

WORKSHOP 1 - TEMA: RADIOLOGIA - Palestrante: Dr. Danilo Tamamaru de Souza

WORKSHOP 2 -TEMA: GINECOLOGIA E OBSTETRÍCIA - Palestrante: Dra. Karla Regina Anacleto Izidorio

WORKSHOP 3 - TEMA: INTUBAÇÃO, SUTURA E NÓ - Palestrante: Dr. Ricardo Hatakeyama / Interno Gilson Barbosa Guimarães

WORKSHOP 4 - TEMA: ORTOPEDIA - Palestrante: Dr. Ibsen Arsioli Pinho

WORKSHOP 5 - TEMA: QUEIMADOS - Palestrante: Dr. Luiz Satochi Fukagawa

11/04-ONCOLOGIA

Coordenador Docente: Dr. Julie Massayo Maeda Oda

Coordenador Discente: Daniela Muniz

Apresentação cultural (Flávio e Beatriz Gurgel)

Palestra I: ATUALIDADES EM ONCOLOGIA - Dr. Everton Pontes Martins

Palestra II: EFICÁCIA DA RADIOLOGIA NO SETOR ONCOLÓGICO - Dr. Adir Pires Maia

Palestra III: INOVAÇÕES TERAPÊUTICAS NA ONCOLOGIA - Dr. Alex Martins Machado

12/04 - APRESENTACÃO DE TRABALHOS CIENTÍFICOS

APRESENTAÇÃO ORAL E POSTER - BLOCO VIII UNIDADE II UFMS

12/O4 - GASTROENTEROLOGIA

Coordenador Docente: Dr. Thiago Bosch Viana

Coordenador Discente: Vivian Magalhães

Apresentação cultural (Larissa Tsukuda e Alexandre Mozart)

Palestra I: RASTREAMENTO DE CÂNCER DE COLON - Dr. Valdeir Queiroz

Palestra II: ABDÔME AGUDO INFLAMATÓRIO: ABRANGÊNCIA DA LAPAROSCOPIA - Dr. Thiago Bosch Viana

13/04 - MEDICINA INTENSIVA

Coordenador Docente: Dr. Luis Fernando Baldino Lopez

Coordenador Discente: Luis Gustavo Carvalho Barcelos

Apresentação cultural (Orquestra da Casa de Cultura de Três Lagoas)

Palestra I: ATENDIMENTO INICIAL AO QUEIMADO: O QUE TODO MÉDICO DEVE SABER? - Drà. Suelen Melão

Palestra II: CHOQUE CARDIOGÊNICO E DISPOSITIVO DE ASSISTÊNCIA VENTRICULAR - Dr .Luis Fernando Baldino Lopez

Palestra III: ASPECTOS MOLECULARES DOS PRINCIPAIS AGENTES DA SEPSE - Dr. Luiz Euribel Prestes Carneiro

13/04 - CARDIOLOGIA

Coordenador Docente: Dr. Ulisses Calandrin

Coordenador Discente: Rithelle Sampaio

Palestra I: SÍNDROME CORONARIANA AGUDA: FISIOPATOLOGIA, ADMISSÃO E TRATAMENTO EMERGENCIAL - Dr. Ulisses Calandrin

Palestra II: TERAPÊUTICA INTERVENCIONISTA E HEMODINÂMICA NA SÍNDROME CORONARIANA AGUDA - Dr. Diego da Silveira da Costa

Palestra III: CIRURGIA CARDÍACA E COMPLICAÇÕES NA SÍNDROME CORONARIANA AGUDA - Dr. Rafael Schneidewind

PREMIAÇÃO DOS TRABALHOS CIENTÍFICOS

17:00 Show de encerramento (Ana e os agregados) 

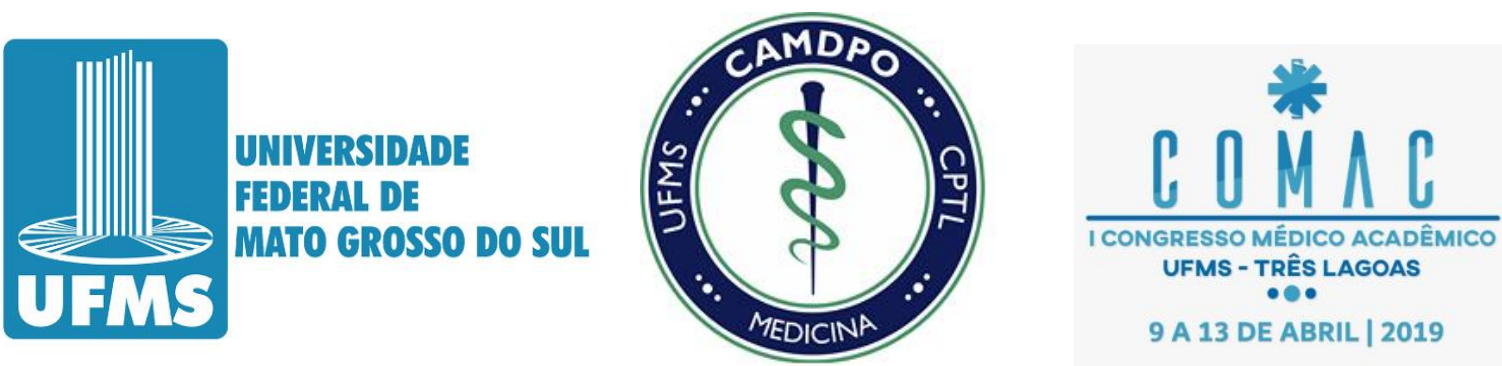

\section{PREMIAÇÃO}

\section{Categoria Oral - Primeiro Lugar}

Análise microbiológica preliminar de amostras isoladas em superfícies inanimadas da Unidade de Terapia Intensiva (UTI) de um hospital de Três Lagoas, MS.

Oliveira, M. D.; Morais, J. C. R.; Souza, R. F.; Bernardes, L. G.; Machado, A. R. S. R.; Machado, A. M. (Universidade Federal de Mato Grosso do Sul- Campus Três Lagoas)

\section{Categoria Oral - Segundo Lugar}

Mensuração do forame jugular em crânios secos da região centro-oeste do Mato Groso do Sul.

Caldeira, J.V.C.; Godas, A.G.L.; Carvalho G.B.A.; Oda, J.Y.; Almeida, P.F.; Silva, A.V.

(Universidade Federal de Mato Grosso do Sul - Campus de Três Lagoas)

\section{Categoria Oral - Terceiro Lugar}

Avaliação da vulnerabilidade de idosos cadastrados na Estratégia Saúde da Família. Andrade, N.O.; Alencar, T.S.; Oliveira, F.C.; Alves, A.M.; Martins, T.C.R.; Luchesi, B.M. (Universidade Federal de Mato Grosso do Sul - Campus de Três Lagoas)

\section{Categoria Poster - Primeiro Lugar}

Avaliação do desempenho cognitivo de adultos e idosos cadastrados na Estratégia Saúde da Família. Oliveira, F.C.; Andrade, N.O.; Alencar, T.S.; Alves, A.M.; Martins, T.C.R.; Luchesi, B.M. (Universidade Federal de Mato Grosso do Sul - Campus de Três Lagoas)

\section{Categoria Poster - Segundo Lugar}

O papel masculino no contexto da gravidez em escolares: um relato de experiência.

Parente, G. S.; Cesário, E. S.; Gama, I. C.S.; Bogado, S. S.G. Pessalacia, J.D.R.

(Universidade Federal de Mato Grosso do Sul - Campus de Três Lagoas)

\section{Categoria Poster - Terceiro Lugar}

Caracterização epidemiológica associada à Leishmaniose Visceral em Três Lagoas e mapeamento dos casos do ano de 2018.

Carvalho, G. B. A.; Godas, A. G. L.; Oliveira, M. D.; Caldeira, J. V. C.; Machado, A. M.; Machado, A. R. S. R. (Universidade Federal de Mato Grosso do Sul - Campus de Três Lagoas) 

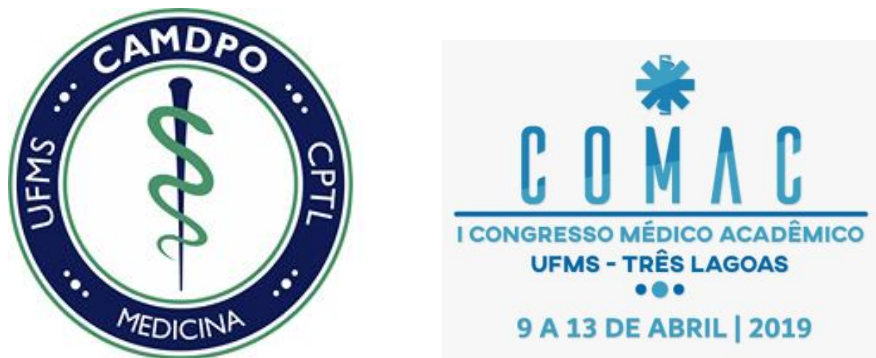

\section{Resumas das}

\section{Trabalkas Apresentadas}

Atenção: Os conteúdos apresentados a seguir bem como a redação empregada para expressá-los são de inteira responsabilidade de seus autores. O texto final de cada resumo está aqui apresentado da mesma forma com que foi submetido pelos autores. 


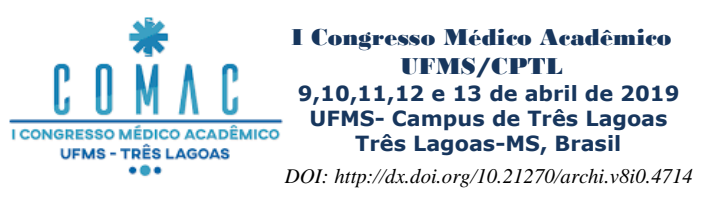

\section{A ALIENAÇÃo PARENTAL E A SAÚde MENTAL DE PACIENTES VÍtimas das AGRESSÕES PSICOLÓGICAS DELA DECORRENTES}

Pereira, I.; Yamaguti, N.G.; Moreira, A.S.

irismar.dicky08@gmail.com

Universidade Federal de Mato Grosso do sul - Campus de três Lagoas

Categoria: Pôster

Com a dissolução da unidade familiar de modo litigioso, as crianças e adolescentes, que são os mais vulneráveis membros da família, acabam sofrendo consequências bastante danosas. Tal situação torna-se um cenário propício para que ocorra o fenômeno da Alienação Parental. Esse fenômeno é recorrente em contexto de disputas de custódia em que o genitor(a) guardião, detentor de guarda unilateral, não mede esforços para dificultar a manutenção do vínculo afetivo entre a criança e o genitor(a) não guardião, aquele que possui apenas o direito de visitação. Tal anomalia comportamental do(a) genitor(a) alienador(a) pode ocorrer pela falta de maturidade psicológica frente ao contexto de dissolução conjugal e à dificuldade de compartilhamento de guarda dele decorrentes. Assim, é objetivo deste trabalho demonstrar a importância da manutenção do vínculo afetivo entre genitores e filhos, mesmo em caso de divórcios, e identificar as consequências patológicas decorrentes da alienação parental. Para se atingir tais objetivos, o método foi o de revisão bibliográfica para levantamento de material, que, em seguida, foi posto em análise quantitativa e qualitativa pelo método análise de conteúdo, proposta por Bardin. Estudos recentes demonstraram que a maioria das crianças e/ou adolescentes que vivenciam situações de violência psicológica são propícias a desenvolverem transtornos psíquicos de difícil reversão, pois, não possuem estrutura de ego completamente formada capaz de se defender. Diante disso, concluímos que é fundamental que se preserve a saúde mental da criança e do adolescente vítimas de agressões psicológicas resultantes da separação dos pais.

Descritores: Relações Pai-Filho; Psicopatologia; Transtornos Mentais. 


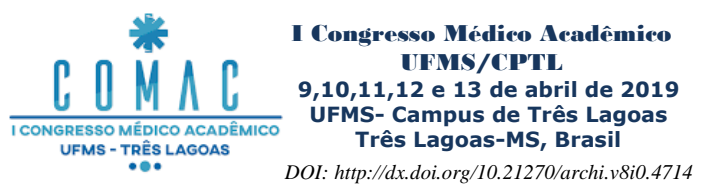

\section{A EFICÁCIA DA LASERTERAPIA NO TRATAMENTO DE CICATRIZES DE ACNE: UMA REVISÃO BIBLIOGRÁFICA}

Pereira, L.V.R.C.; Weis, M.; Jurado, S.R.

luanyratier@gmail.com

Universidade Federal de Mato Grosso do Sul - Campus de Três Lagoas

Categoria: Pôster

A acne é uma doença crônica causada pela Propionibacterium acnes que coloniza as unidades pilossebáceas e não apenas uma afecção limitada à adolescência. Ela se apresenta na forma inflamatória e não inflamatória e é recorrente em locais como tórax, costas e face. As cicatrizes atróficas deixadas por essa inflamação é a principal queixa dos pacientes acometidos por essa doença, gerando grande desconforto estético. A laserterapia tem se revelado efetiva no tratamento dessas cicatrizes. O objetivo desse trabalho foi avaliar na literatura a eficácia do tratamento de cicatrizes de acne instituída por terapia a laser. Tratou-se de revisão bibliográfica integrativa, realizada no período de 2008 a 2018, nas bases de dados Literatura Latino-Americana e do Caribe em Ciências da Saúde (LILACS) e Sistema Online de Busca e Análise de Literatura Médica (MedLine), sendo utilizados os Descritores em Ciências da Saúde (DeCS) "terapia a laser"[and] "cicatriz" [and] "acne". A pesquisa inicial identificou 195 artigos, no entanto, foram selecionados dez artigos com base nos critérios pré-estabelecidos. Os resultados foram melhores nos indivíduos que receberam quatro ou mais sessões de laserterapia, melhorando tanto a textura e a aparência quanto o relevo cutâneo. São evidentes os benefícios da terapia com diferentes tipos de laser, destacando-se os lasers fracionados de dióxido de carbono e de érbio. Os estudos apontaram que os lasers fracionados eram melhores do que os ablativos, pois, os primeiros agiam de forma localizada, sendo os danos em pontos focais e mantendo a superfície da pele íntegra, além de promover menor desconforto ao paciente e estimular a neocolagênese. Utilizando parâmetros e cuidados adequados, a literatura demonstrou que a laserterapia é método eficaz e seguro para o tratamento de cicatrizes de acne

Descritores: Terapia a Laser; Acne; Cicatriz. 


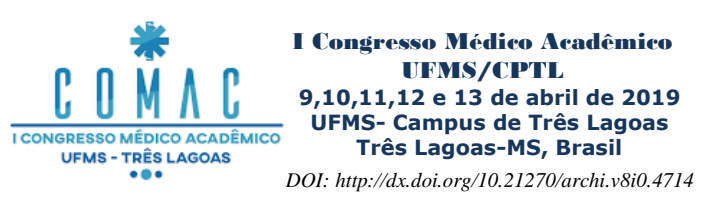

\section{A INCERTEZA NO DIAGNÓSTICO DE TUBERCULOSE MULTIRRESISTENTE E TUBERCULOSE ASSOCIADA A MICOBACTÉRIA NÃO TUBERCULOSA: RELATO DE CASO}

Moura-Fé, V.V.; Konzen, F.T.; Zanette, M.L.; Carrati, P.O.F.; Lima, V.P.B.; Santos, D. vilianveloso@ hotmail.com.

Universidade Federal do Mato Grosso - Campus Sinop - Instituto de Ciências da Saúde

Categoria: Apresentação Oral

As micobactérias provocam enfermidades com características clínicas, bacteriológicas e radiológicas muito semelhantes, dificultando o trabalho dos profissionais da saúde. Paciente J.C.S, homem, 50 anos, residente em Sinop. Sem diagnóstico de HIV. Nega tabagismo. Marca BCG presente. Há 4 anos compareceu à Unidade Básica de Saúde com queixa de hemoptise. Relatou tosse crônica e produtiva, evoluindo com sudorese noturna e febrícula vespertina; com isso, foi solicitado tomografia de tórax, que evidenciou características de lesão por micobactéria. Baciloscopia de escarro negativa em duas amostras. Iniciou tratamento com o esquema Rifampicina +Isoniazida + Pirazinamida + Etambutol (RHZE) por 2 meses, seguido de RH por 4 meses. A cultura de escarro demonstrou tuberculose (TB) atípica. Após 1 ano do término da medicação, paciente retorna com os mesmos sintomas, exceto hemoptise. Raio-X de tórax evidenciou opacidades heterogêneas mal delimitadas, reticulonodular na metade superior dos dois pulmões. Baciloscopia do escarro positiva em duas amostras, encaminhando o paciente para Centro de Referência em Tuberculose de Sinop. Novo exame de cultura de BAAR positivo para micobactéria não tuberculosa (MNT). Cerca de 2 meses após o início dos sintomas, iniciou tratamento com esquema RHZE, enquanto aguardava identificação de patógeno e antibiograma. Com resultado, houve ajuste para Claritromicina e Moxifloxacino, junto com E, R e Pantoprazol, aliado por 6 meses à Amicacina. Durante este tratamento, a medicação não chegou corretamente à cidade. Continua o uso das medicações, exceto Amicacina. Nova cultura de escarro positiva para MNT e TB. Na última radiografia de tórax, constatouse piora do quadro radiológico. Relata astenia, dispneia aos grandes esforços e melhora dos sintomas desde o início do tratamento. Logo, percebe-se a dificuldade no tratamento de micobactérias e a influência dos fatores de risco para bactéria multirresistente. Verifica-se a importância em determinar a etiologia do quadro - que tudo indica ser uma TB-Multirresistente associada a MNT. A falta de um diagnóstico preciso culminou na instituição de um tratamento que trouxe alívio parcial dos sintomas, mas que pode ter potencializado a infecção.

Descritores: Estudos de Casos e Controles; Tuberculose Resistente a Múltiplos Medicamentos; Infecções por Micobactéria não Tuberculosa. 


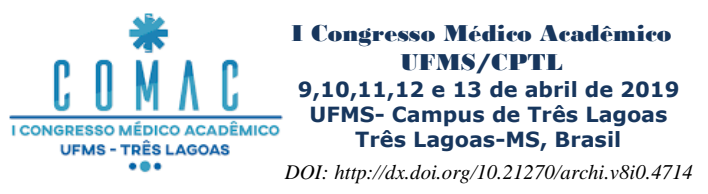

\section{A COOCORRÊNCIA ENTRE TABAGISMO E TRANSTORNO BIPOLAR}

Caixeta, T.V.; Lima, C.R.; Boas, C.V.; Scorsin, G; Moreira, A.S.

thaissacaixeta@gmail.com

Universidade Federal de Mato Grosso do Sul - Campus de Três Lagoas

Categoria: Pôster

O tabagismo carrega resquícios históricos de um simbolismo de glamour, status e independência frente à sociedade. Atualmente a alta prevalência de fumantes e da mortalidade decorrente de doenças relacionadas garante ao tabagismo o reconhecimento como um problema de saúde pública. Nessa linha, o uso de tabaco, dentre outras drogas, aparece como comorbidade frequente no transtorno afetivo bipolar. Estudos apontaram que o vício em substâncias (tabaco, álcool, etc.) e o transtorno bipolar podem ser hereditários. Tendo em vista o amplo espectro que recobre a relação entre o transtorno bipolar e o uso de cigarros e a possibilidade de danos à saúde individual e coletiva, este trabalho objetiva compreender a dinâmica biopsicossocial da coocorrência entre tabagismo e transtorno bipolar, entender e correlacionar a dependência psicológica no tabagismo com o comportamento compulsivo no transtorno bipolar. Por meio do método de revisão da literatura na base de dados Biblioteca Virtual em Saúde (BVS - Regional), com os descritores tabagismo, transtorno bipolar, nicotina e coocorrência. Identificamos grande suscetibilidade ao tabagismo por portadores de transtornos de humor, sendo as motivações para tal de ordem bioquímica, genética e psicossocial. Alterações no circuito de recompensas, envolvendo neurotransmissores como a dopamina, associadas à busca pela remissão de sintomas de humor são destacadas como possíveis origens da coocorrência. Denotamos a necessidade de uma articulação entre os aspectos biológicos, psicológicos e sociais almejando a manutenção, o tratamento e, sobretudo, a prevenção da coocorrência, ressaltando a eficácia das abordagens psicoterápicas no tratamento desta.

Descritores: Comorbidade; Tabagismo; Transtorno Bipolar. 


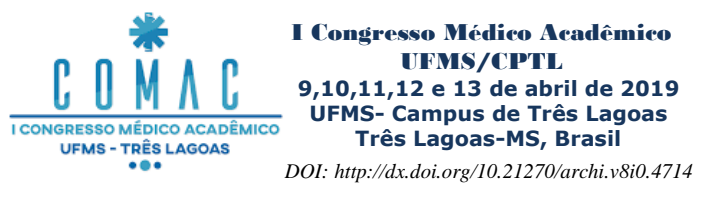

\section{AÇÕES EXTENSIONISTAS DE ARTE PARA A SAÚdE E A QUALIDADE DE VIDA NO CAMPUS DE TRÊS LAGOAS/UFMS}

Gurgel, B. V.; Saraiva, K V. de O.

beatrizvieiragurgel@gmail.com

Universidade Federal de Mato Grosso do Sul - Campus de Três Lagoas

Categoria: Pôster

Arte e cultura promovem a saúde e a boa convivência social. Quando ofertadas na universidade propiciam qualidade de vida aos indivíduos que convivem no ambiente educacional. Conscientes que a implantação de um projeto dessa natureza era de urgência no campus de Três Lagoas, criamos o projeto de extensão Arte, Educação e Saúde, sobre o qual desenvolvemos este trabalho. Nossos objetivos foram incentivar a arte e a expressão cultural no CPTL com a busca ativa e a manifestação de talentos na comunidade acadêmica, incluindo discentes, docentes, técnicos e terceirizados, e estimular a produção artística que valorizasse a cultura, como forma de inclusão socioeducativa e fortalecimento da extensão universitária. Apresentamos um relato de experiência sobre o Projeto, que contou com uma bolsista do curso de Medicina, iniciado em 2018.2. Realizamos dezenas de atividades artísticas, uma a duas vezes/semana, durante as refeições no restaurante universitário (RU), com as seguintes pautas: declamação de poesias, música erudita e popular com cantores, solistas de instrumentos clássicos e violeiros. Relaxamento, exercícios físicos e rodas de conversa também foram oferecidas ao público. Um ponto significativo do Projeto foi a colaboração de artistas da Diretoria de Cultura e a criação do coral formado por alunos, professores e servidores, que findou as atividades do semestre com apresentações públicas. Participaram como espectadores aproximadamente 1.400 pessoas, transeuntes e frequentadores do RU. Houve ações nas quais os universitários foram protagonistas, mostrando seus talentos. Concluímos que foi possível implementar uma rotina de atividades artísticas, reconhecida pela comunidade acadêmica, com mudança na ambiência do campus, tornando-o um local de convívio e trocas culturais mais agradável e saudável.

Descritores: Cultura; Educação em Saúde; Arte.

Apoio: PROECE/UFMS (Edital 16/2018 


\author{
CRANIOENCEFÁLICO GRAVE \\ Pimenta, A.S.; Ferrareto, N.S.; Silva, A.V. \\ mandaspiment@gmail.com \\ Universidade Federal de Mato Grosso do Sul - Campus de Três Lagoas \\ Categoria: Apresentação Oral
}

ANÁLISE DAS SEQUELAS EM PACIENTE VÍTIMA DE TRAUMATISMO

Traumatismo cranioencefálico (TCE) consiste em agressão traumática ao cérebro, por causa externa, que culmine em lesão anatômica ou alterações encefálicas fugazes ou infindáveis, de caráter cognitivo ou motor. Uma das consequências do TCE é o hematoma extradural agudo, decorrente do descolamento da dura-máter em relação à tábua interna do crânio, provocada por ruptura de vasos meníngeos. Paciente (LAS), sexo feminino, 37 anos, foi encaminhada ao Pronto Atendimento em Governador Valadares - MG, no dia 12 de outubro de 2005, com otorragia, êmese e crises álgicas generalizadas, 10 horas após ter sido vítima de acidente automobilístico, sendo constatado um TCE. Após avaliação primária, solicitou-se tomografia computadorizada, a partir da qual verificou-se hematoma extradural temporal esquerdo e de fossa posterior à esquerda e contusão fronto-basal direita. Foi submetida com caráter de urgência à craniotomia temporal esquerda, na mesma data. Inicialmente, LAS apresentou déficit de memória recente, labilidade do humor, instabilidade afetiva e de personalidade, e anosmia. Em julho de 2009, após avaliação neuropsiquiátrica, constatou-se processo de frontalização com alteração da personalidade, déficit cognitivo com comprometimento de memória de fixação, dificuldade de raciocínio lógico, alterações de humor, intolerância à frustração, irritabilidade, sintomas ansiosos, adinamia, anedonia, evitamento social e dependência nas tarefas do cotidiano. A perda de massa cerebral frontal e temporal justifica os sinais supracitados. A paciente é portadora de transtorno crônico evoluindo desde outubro de 2005. Hodiernamente, a vítima persiste com poucas sequelas, como alterações de sono e perda do paladar e olfato, entretanto já retomou as atividades laborativas e teve melhora importante no quadro neurocognitivo comportamental e funcional.

Descritores: Traumatismos Craniocerebrais; Complicações; Neurologia. 


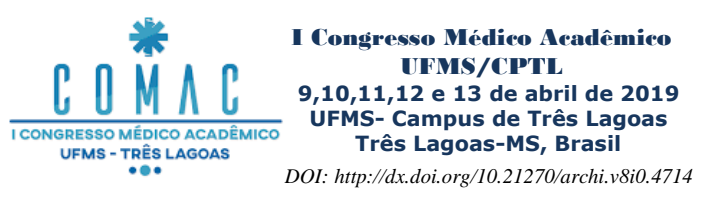

\section{ANÁLISE MICROBIOLÓGICA PRELIMINAR DE AMOSTRAS ISOLADAS EM SUPERFÍCIES INANIMADAS DA UNIDADE DE TERAPIA INTENSIVA (UTI) DE UM HOSPITAL DE TRÊS LAGOAS, MS.}

Oliveira, M.D.; Morais, J.C.R.; Souza, R.F.; Bernardes, L.G.; Machado, A.R.S.R.; Machado, A.M.

mirianoliver2006@hotmail.com

Universidade Federal de Mato Grosso do Sul- Campus Três Lagoas

Categoria: Apresentação Oral

Pacientes em ambientes hospitalares estão expostos a uma variedade de microrganismos patogênicos, principalmente em UTIs. Estes microrganismos, muitas vezes resistentes a um amplo espectro de antibióticos devido a pressão seletiva constante, podem permanecer viáveis em superfícies inanimadas. Objetivou-se então investigar o perfil microbiológico existente em superfícies inanimadas do setor de UTI de um hospital de Três Lagoas, MS. Amostras da superfície de 5 leitos (biombo, maca, painel, esfigmomanômetro e bomba de infusão), equipamentos e instrumentos do interior da UTI (teclado e mouse de computador, telefone e portas de acesso) foram recolhidas utilizando swab estéril embebido em solução fisiológica. As amostras (134) foram semeadas em ágar sangue e as colônias obtidas foram isoladas em meio Mueller Hinton, e identificadas seguindo protocolo padrão. Foram isoladas 267 colônias, das quais, 198 pertencem ao gênero Staphylococus $(74,15 \%)$, onde o Staphylococcus epidermidis foi o mais prevalente (62,6\%), seguido do Staphylococcus aureus (31,3\%) e Staphylococcus saprophyticcus $(6,1 \%)$. O gênero Staphylococcus está comumente associado a infecções de pele e/ou feridas e seu controle é essencial no ambiente hospitalar. Adicionalmente, identificamos 11 bacilos gram negativos $(4,11 \%)$, pertencentes à família Enterobacteriacea, responsáveis por uma gama de gastroenterites. Uma triagem inicial suspeita-se de Pseudomonas spp e Klebsiella spp, entretanto, testes adicionais para a identificação final estão em processamento. Foram isolados 32 bacilos gram positivos (11,98\%), com a presença de morfologia e esporos sugestivos de Bacillus subtilis e Bacillus cereus, bactérias de solo, plantas e cereais, produtoras de toxinas. Conclui-se que o monitoramento é imprescindível para controle de cepas patogênicas e multirresistentes.

Descritores: UTI; Perfil Microbiano; Antimicrobianos. 


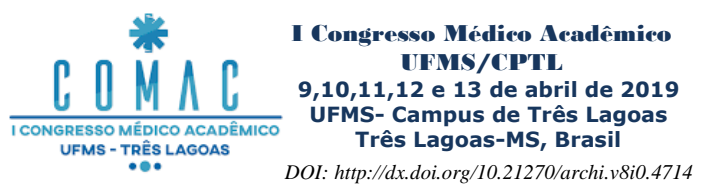

\section{AURICULOTERAPIA PROMOVE MELHORAS NOS SINTOMAS DO OMBRO DOLOROSO: UM ESTUDO DE CASO}

Facina, M. E. L.; Oda, J. Y.

dudaleitef@hotmail.com

Universidade Federal do Mato Grosso do Sul - Campus de Três Lagoas

Categoria: Pôster

A medicina tradicional chinesa (MTC) é uma terapêutica já incorporada à Política Nacional de Práticas Integrativas e Complementares do SUS. Um dos recursos terapêuticos é a auriculoterapia, que promove a regulação psíquico-orgânica por estimular pontos energéticos dispostos na orelha. Essa técnica utiliza a teoria dos cinco elementos como base para diagnóstico energético e orgânico do indivíduo. Paciente R.C.A., sexo feminino, 64 anos, solteira, aposentada, residente da cidade de Niterói/RJ. Apresentou como queixa principal dor muscular na região dos ombros, iniciada após atividade física intensa dois dias antes. Durante a anamnese integrativa, relatou preferência alimentar pelos sabores salgado, doce e ácido; afirmou não gostar inverno, preferindo a primavera; e informou preferir calor e vento à clima frio. Informou preocupação como emoção frequente. Quanto à problemas frequentes, queixou-se de dores musculares e problemas visuais e vasculares. Durante inspeção do pavilhão auricular foi observado hiperemia no ponto relativo à ansiedade. Feito o diagnóstico energético, foram aplicados cristais nos pontos energéticos Shen Men, rim, simpático, pulmão 1, pulmão 2, intestino delgado, relaxamento muscular e ombro, objetivando o reequilíbrio energético e a analgesia. A paciente relatou ardência na orelha no momento da aplicação e, após algumas horas, alívio da dor na região dos ombros. O processo álgico foi completamente solucionado alguns dias após o tratamento. Apesar da MTC ser milenar, no Brasil suas técnicas ainda são pouco pesquisadas e aplicadas. O uso combinado das medicinas halopática e alternativa sinalizam a otimização da atenção à saúde. Como trata-se de um método de prevenção e tratamento de baixo custo, fácil aplicação e resultados significativos, novos estudos se fazem necessários nesta área.

Descritores: Medicina Tradicional Chinesa; Auriculoterapia; Mialgia. 


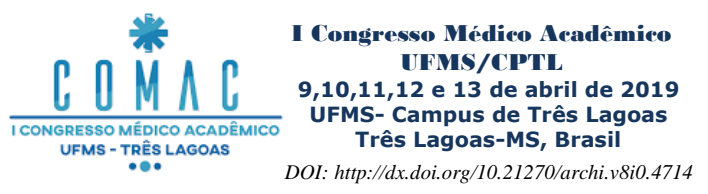

\section{AUTOPERCEPÇÃO DA SAÚdE E CONSUMO DE MEDICAMENTOS DE ADULTOS E IDOSOS CADASTRADOS NA ESTRATÉGIA SAÚDE DA FAMÍLIA}

Carrijo, M.F.; Ribeiro, A.M.F.; Augusto, A.C.S; Silva, L.A.; Luchesi, B.M.; Martins, T.C.R. Graduação em Medicina, Campus de Três Lagoas, Universidade Federal de Mato Grosso do Sul marifcarrijo@gmail.com

Categoria: Pôster

A transição epidemiológica e consequente aumento das doenças crônico-degenerativas, pode ter como consequência o aumento do consumo contínuo de medicamentos. A Estratégia Saúde da Família (ESF), devido ao seu caráter multidisciplinar e de integralidade, tem grande potencial para orientar os pacientes e garantir o uso racional de fármacos, uma vez que estes aspectos podem influenciar no seu estado de saúde. O objetivo foi avaliar a autopercepção de saúde e sua relação com consumo de medicamentos em adultos e idosos cadastrados na ESF do município de Três Lagoas/MS. Trata-se de um estudo transversal e quantitativo, realizado no período de 2018/2019, em indivíduos com idade $\geq 45$ anos, de ambos os sexos, cadastrados na ESF do município. O instrumento de coleta de dados utilizado foi um questionário estruturado. A autopercepção da saúde foi avaliada por uma pergunta direta e objetiva, sendo categorizada em ruim/regular ou boa/excelente. O tratamento dos dados foi feito por meio da estatística descritiva com distribuição de frequências. Dos 99 participantes, 62,6\% eram mulheres. A média de idade foi 62,28 anos $( \pm 11,020)$. Houve predomínio de indivíduos com companheiro $(52,5 \%)$, que possuíam de 5-8 anos de escolaridade $(32,3 \%)$ e com autopercepção da saúde negativa $(50,5 \%)$. A prevalência de consumo de medicamentos foi de $79,8 \%$. Entre aqueles que fazem uso de medicamento a maioria tem uma autopercepção negativa da saúde $(55,7 \%, \mathrm{p}=0,048)$. Normalmente, os pacientes procuram nos medicamentos um recurso para melhorar sua condição. Entretanto, os efeitos adversos e interações medicamentosas podem agravar o estado de saúde. Correlacionar o consumo de medicamentos com a autopercepção de saúde é importante para redefinir as políticas públicas relacionadas com a melhoria da qualidade de vida da população.

Descritores: Atenção Primária à Saúde; Envelhecimento; Medicamentos de Uso Contínuo. 


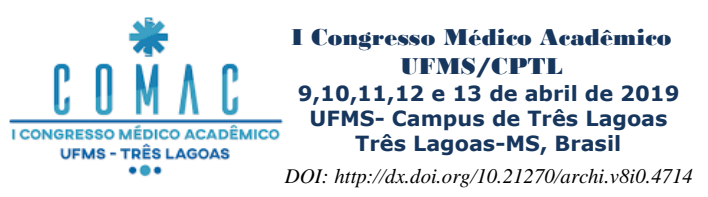

\section{AUTOPERCEPÇÃO DE SAÚDE DE ADULTOS E IDOSOS CADASTRADOS NA ESTRATÉGIA SAÚDE DA FAMÍLIA}

Silva, L. A.; Ribeiro, A.M.F.; Augusto, A.C.S; Carrijo, M.F.; Luchesi, B.M.; Martins, T.C.R. lualvesiza@hotmail.com

Universidade Federal de Mato Grosso do Sul - Campus de Três Lagoas

Categoria: Pôster

A autopercepção de saúde, ao incorporar diversos aspectos necessários ao bem estar e contentamento individual, se revela como um instrumento de qualificação da realidade biopsicossocial em estudo. $\mathrm{O}$ objetivo deste estudo foi descrever a autopercepção de saúde e os fatores relacionados em adultos e idosos cadastrados na Estratégia Saúde da Família (ESF) do município de Três Lagoas/MS. Trata-se de um estudo transversal e quantitativo, realizado no período de 2018/2019, incluindo 99 indivíduos com idade $\geq 45$ anos, de ambos os sexos. A avaliação da autopercepção de saúde foi obtida por meio de questão direta e objetiva, sendo categorizada em boa/muito boa e muito ruim/ruim/regular. A maioria dos participantes era do sexo feminino $(62,6 \%)$, com idade $\geq 60$ anos $(52,5 \%)$, possuía de $5-8$ anos de escolaridade $(32,3 \%)$ e possui uma autopercepção negativa da saúde $(50,5 \%)$. O sexo masculino $(54,1 \%)$ se mostrou com pior autopercepção de saúde. Apresentaram uma maior proporção de autopercepção negativa da saúde pessoas com idade $\geq 60$ anos $(51,9 \%)$, não ter companheiro $(51,1 \%)$, ter menor escolaridade $(52,8 \%)$ e menor renda $(64,7 \%)$. A prevalência de autopercepção negativa foi semelhante em outros estudos, entretanto, houve uma maior proporção entre os homens - achado contrário de outros estudos. Outros fatores como renda familiar e escolaridade também apresentaram consideráveis influências, sendo corroborado por outros estudos. Destarte, a autopercepção referida se constitui como um indicativo favorável à prevenção da senilidade e suas respectivas implicações nocivas para sociedade. Conclui-se que é de suma importância conhecer quais são os fatores estressores a serem abordados pela equipe multiprofissional, uma vez que, a autopercepção da saúde impacta a qualidade de vida da população.

Descritores: Autopercepção; Estudos Transversais; Saúde do Idoso. 


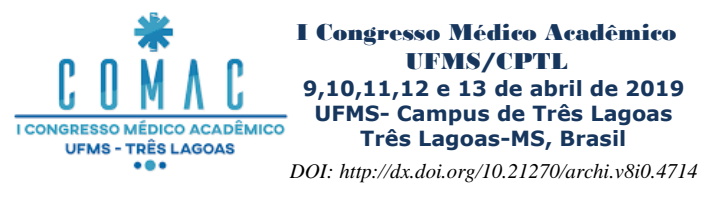

\section{AVALIAÇÃO DA INCIDÊNCIA DO FORAME DE VESÁLIUS (FORAME EMISSÁRIO ESFENOIDAL) CRÂNIOS SECOS PROVENIENTES DA REGIÃO CENTRO-OESTE DO BRASIL}

Godas, A.G.L.; Caldeira, J.V.C.; Carvalho,G.B.A.; Da Silva, K.R.T.; Oda, J.Y.; Silva,A.V. andrelgodas@gmail.com

Universidade Federal do Mato Grosso do Sul - Campus Três Lagoas

Categoria: Pôster

O forame emissário esfenoidal, forame de Vesálius (FV), localizado na asa maior do osso esfenoide, transmite veias emissárias conectando o seio cavernoso com o plexo venoso pterigoideo. Também comunicam veias extracranianas e intracranianas tornando-se uma importante rota de drenagem sanguínea em casos de aumento da pressão intracraniana. O objetivo deste estudo foi averiguar a incidência e variações morfológicas e morfometrias do forame de Vesálius em crânios de diferentes gêneros (masculino e feminino), através de crânios secos do Centro-oeste do Brasil. Selecionou-se uma amostra de 108 crânios humanos, 54 crânios masculinos e 54 crânios femininos. Os crânios foram limpos e seccionados no sentido fronto-occipital. Observou-se então na base do crânio o osso esfenoide a incidência do Forame de Vesálius. Os forames encontrados foram classificados em redondo, oval e irregular. $8,1 \%$ dos crânios masculinos possuem FV, sendo $0,6 \%$ no lado esquerdo ( $75 \%$ oval e $25 \%$ redondo), $1,8 \%$ no lado direito ( $50 \%$ redondo, $25 \%$ irregular e $25 \%$ oval) e $0,15 \%$ bilateralmente. $12,42 \%$ dos crânios femininos possuem FV, sendo $2,8 \%$ no lado esquerdo (58,3\% redondo, $8,3 \%$ oval e $16,7 \%$ irregular), 2,0\% no lado direito (44,4\% redondo, 33,3\% oval e 33,3\% irregular) e $0,5 \%$ bilateralmente. A comparação da incidência do FV, de acordo com sexo (masculino e Feminino), corroborou com trabalhos existentes na Índia. Já a relação da incidência do FV, Comparando os lados (esquerdo, direito e bilateral), assim como sua morfometria (redondo, oval e irregular) também foram encontrados em outros estudos. O estudo da anatomia craniana nos diversos países permite um detalhado conhecimento anatômico e assim o avanço no desenvolvimento e na realização de técnicas cirúrgicas mais seguras, principalmente na microneurocirurgia.

Descritores: Forame; Anatomia; Crânio.

Apoio: Bolsa UFMS - PIBIC/PIBIC-AF/PIBITI (095/2018 n²41472.601.20376.0905201) 


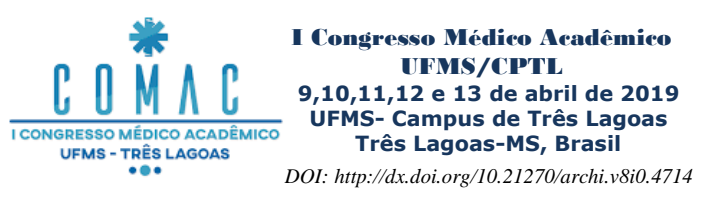

\section{AVALIAÇÃO DA VULNERABILIDADE DE IDOSOS CADASTRADOS NA ESTRATÉGIA SAÚDE DA FAMÍLIA}

Andrade, N.O.; Alencar, T.S.; Oliveira, F.C.; Alves, A.M.; Martins, T.C.R.; Luchesi, B.M.

noliveiraandrade@gmail.com

Universidade Federal de Mato Grosso do Sul - Campus de Três Lagoas

Categoria: Apresentação Oral

Verifica-se, atualmente, tanto a transição demográfica, quanto a epidemiológica, com um aumento do número de idosos, e também de doenças crônicas não-transmissíveis. É fato que o envelhecimento se baseia em especificidades morfológicas, sociais e psíquicas. Avaliar a saúde global apenas pela idade cronológica não demonstra total eficácia, e o dano às funções homeostáticas pode ser melhor detectado por meio do Índice de Vulnerabilidade Clínico-Funcional-20 (IVCF-20). O objetivo da pesquisa foi avaliar a vulnerabilidade de idosos cadastrados na Estratégia Saúde da Família (ESF). Trata-se de um estudo transversal e quantitativo, realizado no período de 2018/2019, com 52 idosos (idade $\geq 60$ anos), de ambos os sexos, cadastrados nas ESF no município de Três Lagoas-MS. Foram coletados dados de caracterização sociodemográfica e aplicado o IVCF-20, com pontuação possível de 0-40 (quanto maior a pontuação, maior o risco de vulnerabilidade clínico-funcional). Foi calculada a frequência, média e desvio padrão das variáveis. Dos 52 idosos, a maioria era do sexo feminino $(55,8 \%)$, na faixa etária de 60-69 anos (55,8\%), com 1 a 4 anos de escolaridade (40,4\%), renda de 1 a 3 salários mínimos $(48,1 \%)$ e 57,7\%

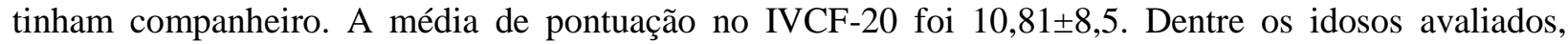
$36,5 \%$ foram classificados com baixo risco de vulnerabilidade clínico funcional, 38,5\% com risco moderado e 25,0\% com alto risco. Os idosos categorizados com moderado e alto risco são predominantes. O diagnóstico dessa condição se destaca por seu significativo valor preditivo, já que a vulnerabilidade se associa intrinsecamente a maior risco de morte, perda de atividades da vida diária, hospitalização, quedas e fraturas. É imprescindível, pois, um planejamento de intervenções preventivas, a fim de proporcionar ampla proteção e saúde ao idoso.

Descritores: Envelhecimento; Vulnerabilidade em Saúde; Idoso Fragilizado.

Apoio: Bolsa de iniciação científica UFMS (Edital PROPP/UFMS 095/2018). 


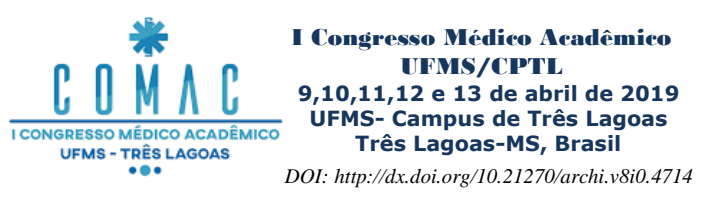

\section{AVALIAÇÃO DO DESEMPENHO COGNITIVO DE ADULTOS E IDOSOS CADASTRADOS NA ESTRATÉGIA SAÚDE DA FAMÍLIA}

Oliveira, F.C.; Andrade, N.O.; Alencar, T.S.; Alves, A.M.; Martins, T.C.R.; Luchesi, B.M..

fernando-carli@hotmail.com

Universidade Federal de Mato Grosso do Sul - Campus de Três Lagoas

Categoria: Pôster

O Brasil está passando por um processo de transição demográfica acelerado. Um dos impactos do envelhecimento populacional é a perda cognitiva, a qual pode afetar também a independência e qualidade de vida dos indivíduos. Avaliar a cognição da população de adultos mais velhos e idosos é importante para subsidiar políticas públicas para a promoção de um envelhecimento saudável, principalmente no contexto da Estratégia Saúde da Família (ESF). Destaca-se a relevância do estudo por mudar o enfoque de pesquisas anteriores, que geralmente ocorrem em municípios maiores localizados na região Sudeste. O objetivo foi avaliar o desempenho cognitivo de adultos e idosos cadastrados na ESF. Trata-se de um estudo transversal e quantitativo, realizado no período de 2018/2019, com 47adultos (45-59 anos) e 52 idosos ( $\geq 60$ anos), de ambos os sexos, cadastrados na ESF no município de Três Lagoas-MS. Foram coletados dados de caracterização sociodemográfica e aplicado o Mini-Exame do Estado Mental (MEEM), com pontuação possível de 0-30 pontos (quanto maior, melhor o desempenho). Foi calculada a frequência, média e desvio padrão das variáveis. A maioria dos participantes era mulher $(62,6 \%)$, com idade $\geq 60$ anos (52,5\%), com companheiro (52,5\%) e com 5-8 anos de escolaridade (32,3\%). A média de pontuação dos idosos no MEEM foi 21,67 $( \pm 4,36)$ e dos adultos $23,87( \pm 3,67)$. Apresentaram pontuação indicativa de alteração cognitiva - ajustada para escolaridade - 9,6\% dos idosos e $21,3 \%$ dos adultos. A porcentagem geral de participantes com pontuação indicativa de déficits foi $15,2 \%$. Os resultados indicam a importância do rastreamento de alterações na função cognitiva, principalmente nas pessoas em processo de envelhecimento (45-59 anos), faixa etária na qual é possível planejar intervenções visando minimizar os déficits cognitivos e suas consequências na velhice.

Descritores: Cognição; Testes de Estado Mental e Demência; Estratégia Saúde da Família.

Apoio: Bolsa de iniciação científica CNPq (Edital PROPP/UFMS 095/2018). 


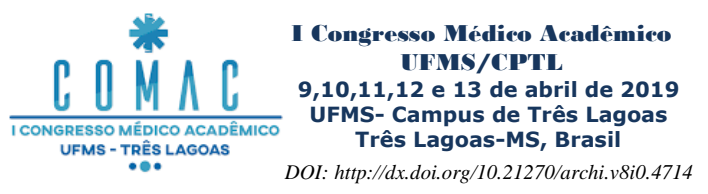

\section{BIOMARCADORES DE IMPORTÂNCIA CLÍNICA NA DISTROFIA MUSCULAR DE DUCHENNE}

Vilaça, M. P.; Paschoal, A. P.; Iaquinto, M. L.; Argondizzi, R.O.; Oba, T.C.L.; Belini-Júnior, E. marcellopansani@gmail.com

Universidade Federal de Mato Grosso do Sul - Campus de Três Lagoas

Categoria: Pôster

A Distrofia Muscular de Duchenne (DMD) é caracterizada por mutações no gene $D M D$ com padrão recessivo ligado ao cromossomo $\mathrm{X}$. Outras mutações no gene $D M D$ causam uma distrofia branda, distrofia muscular de Becker (BMD). As pessoas com DMD apresentam quadro progressivo e degenerativo, levando à perda de deambulação, insuficiência respiratória e falha cardíaca, entre outros sintomas. A busca de biomarcadores para diagnóstico, prognóstico e monitoramento da DMD têm sido de extrema importância para a prática clínica. Diante disto, o presente trabalho teve o objetivo de relacionar os biomarcadores de interesse clínico com a DMD e BMD. O PubMed foi utilizado como base de dados com os descritores "duchenne muscular dystrophy", "clinical" e "biomarkers". De 80 artigos publicados nos últimos cinco anos, 17 foram incluídos no trabalho com os desfechos: biomarcadores relacionados a DMD e BMD. Vários biomarcadores identificados na DMD são suficientes para discriminar indivíduos saudáveis e com DMD e BMD. Destaca-se os proteicos, como a creatina quinase (CK), indica o dano muscular e útil no diagnóstico após confirmar a falta de distrofina e mutação no gene $D M D$, e a MMP-9 (metaloproteinase) utilizada para progressão da doença; os genéticos, como haplótipo no gene LTB4, associado à perda tardia da deambulação, e os miRNAs (miR-1, miR-133, miR-206, miR-208b e miR499) que são elevados em pacientes com DMD e diferentes dos pacientes BMD. Muitos biomarcadores já foram identificados na DMD com diferentes propósitos (diagnóstico, prognóstico, monitoramento e respondedores a terapias), porém poucos são usados na prática clínica devido à complexidade de traduzir os resultados de pesquisas para uso clínico. Destaca-se a necessidade de biomarcadores adequados à finalidade, descrevendo os desafios associados à qualificação de biomarcadores para aplicações clínicas.

Descritores: Biomarcadores; Distrofias; Afecção Genética. 


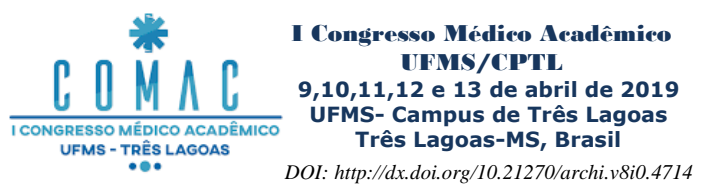

\section{CARACTERIZAÇÃO DA REDE DE APOIO SOCIAL DE ADULTOS E IDOSOS CADASTRADOS NA ESTRATÉGIA SAÚDE DA FAMÍLIA}

Alencar, T. S.; Andrade, N.O.; Oliveira, F.C.; Alves, A.M.; Martins, T.C.R.; Luchesi, B.M.

taienealencar@gmail.com

Universidade Federal de Mato Grosso do Sul - Campus de Três Lagoas

Categoria: Pôster

Redes de apoio sociais são importantes em todas as etapas da vida, principalmente no fim da idade adulta e velhice, períodos de grandes acúmulos de perdas, tanto relacionadas ao processo biológico do envelhecimento quanto aos cenários sociais e psicológicos. As relações sociais permitem ao ser humano sentir-se integrante da sociedade, dá sentido à vida, previne o isolamento e está relacionada à prevenção de doenças de ordens físicas e psicológicas, como a depressão e o declínio cognitivo. O objetivo do estudo foi caracterizar a rede social de adultos e idosos cadastrados na Estratégia Saúde da Família (ESF). Trata-se de um estudo transversal e quantitativo, realizado no período de 2018/2019, com 99 indivíduos com idade $\geq 45$ anos, de ambos os sexos, cadastrados nas ESF no município de Três Lagoas-MS. Foram coletados dados sociodemográficos e dados referentes ao número de pessoas que moram na mesma casa (incluindo o participante), número de familiares e amigos íntimos, participação em grupos sociais e em atividades de lazer, e feita a questão: Você se considera socialmente isolado? Foi calculada a frequência, média e desvio padrão das variáveis. A maioria dos participantes era do sexo feminino (62,6\%), com idade $\geq 60$ anos (52,5\%), possuía de 5-8 anos de escolaridade (32,3\%), renda de 1 a 3 salários mínimos $(53,5 \%)$ e 52,5\% tinham companheiro. A média de pessoas residindo na mesma moradia foi 2,92 $\pm 1,68$ e a

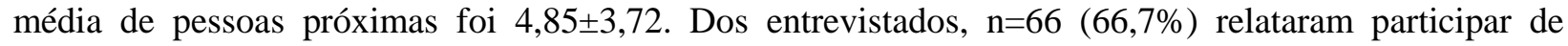
grupos sociais e $n=56(56,6 \%)$ de grupos de lazer. Ademais, $n=35(35,4 \%)$ consideravam-se socialmente isolados. Embora, pouco mais da metade dos entrevistados participem de grupos sociais e lazer, parte significativa considera-se em isolamento social, dados importantes para subsidiar o planejamento e implementação de políticas públicas voltadas para esse público.

Descritores: Rede Social; Envelhecimento; Prevenção Primária. 


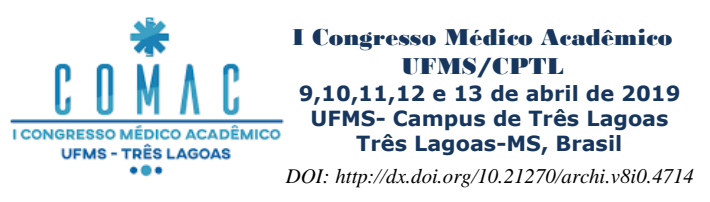

\section{CARACTERIZAÇÃO EPIDEMIOLÓGICA ASSOCIADA À LEISHMANIOSE VISCERAL EM TRÊS LAGOAS E MAPEAMENTO DOS CASOS DO ANO DE 2018}

Carvalho, G.B.A.; Godas, A.G.L.; Oliveira, M.D.; Caldeira, J.V.C.; Machado, A.M.; Machado, A.R.S.R. giovannacarvalh@hotmail.com

Universidade Federal de Mato Grosso do Sul - Campus de Três Lagoas

Categoria: Pôster

A Leishmaniose Visceral (LV) é uma zoonose que atinge humanos e outros animais, com evolução crônica, acometimento sistêmico e, quando não tratada pode levar à óbito. A transmissão ocorre pela picada de fêmeas de insetos hematófagos, do gênero flebotomíneo. Este estudo retrospectivo observacional objetivou analisar a distribuição dos casos de LV em Três Lagoas/MS no ano de 2018. Dados coletados junto a Vigilância Epidemiológica (SINAN) evidenciaram 214 casos notificados, 94 $(43,9 \%)$ do sexo feminino (SF) e $120(56,1 \%)$ do sexo masculino (SM). A idade média, dos casos, foi de 37,2 anos com desvio padrão (SD) de 20,5, sem diferença significativa entre a idade dos participantes do $\mathrm{SF}$ e do SM (teste $\mathrm{t}$ student, $\mathrm{p}=0,3$ ). Foram confirmados 8 casos de $\mathrm{LV}$, concentrados na região sul e leste da cidade, sendo 4 do SM (50\%) e 4 do SF (50\%), com média de idade de 23,7 anos (SD = 23,8), sem diferença significativa da idade entre os sexos $(\mathrm{p}=0,27)$. Observa-se um predomínio de notificação no inverno $(6 / 8-75 \%)$, seguido do período de verão (2/8 - 25\%), corroborando à literatura. O sintoma mais relatado foi febre $(7 / 8,87,5 \%)$, seguida de astenia, emagrecimento e palidez, com $75 \%$ dos relatos $(6 / 8)$. Tosse, esplenomegalia e hepatomegalia foram relatados em 62,5\%. Edema e icterícia em 4/8 (50\%) e 1/8 $(12,5 \%)$ respectivamente. Cinco pacientes relataram outros sintomas não especificados $(62,5 \%)$ e não houve presença de quadro infeccioso. O critério para confirmação dos casos foi laboratorial $(7 / 8,87,5 \%)$ e 1 clínico epidemiológico $(1 / 8,12,5 \%)$. Dos indivíduos confirmados, 2 pacientes evoluíram a óbito $(25 \%)$ e $6(75 \%)$ evoluíram à cura por meio do tratamento específico. Diante do exposto, por tratar-se de uma doença endêmica da região, ressalta-se a importância do monitoramento da doença, visando estabelecer estratégicas eficazes para o controle e combate à doença.

Descritores: Zoonoses, Leishmaniose Visceral; Prevalência.

Apoio: Vigilância Epidemiológica de Três Lagoas, PIBIC-UFMS. 


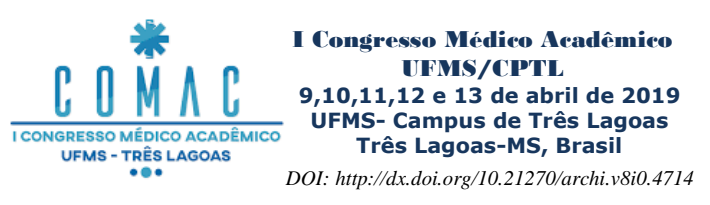

\section{CEFALEIA PÓS-PUNÇÃO DURAL: FISIOPATOLOGIA, DIAGNÓSTICO, FATORES DE RISCO E TRATAMENTO}

Paschoal, A.P.; Gazarini, L.; Almeida, P.F.; Ferreira, U.P.; Macedo, C.E.; Silva, A.V.

appaschoal@live.com

Universidade Federal de Mato Grosso do Sul - Campus de Três Lagoas

Categoria: Pôster

A cefaleia pós-punção dural (CPPD) é a complicação mais frequente decorrente da anestesia subaracnóidea (incidência global de 0,04 a 3\%) e da anestesia epidural $(0,15$ a 1,5\%), e pode impossibilitar o paciente de realizar tarefas diárias. Diante disso, o presente trabalho realizou uma revisão de literatura buscando atualizações acerca da fisiopatologia, diagnóstico, fatores de risco e tratamento da CPPD. O PubMed foi utilizado como base de dados com os descritores "post-dural puncture headache", "anesthesia" e "spinal". De 73 artigos publicados nos últimos cinco anos, 25 foram incluídos. A CPPD resulta da recuperação tardia da dura-máter após sua punção intencional ou não intencional (no caso da anestesia epidural). A perda liquórica pelo orifício dural aberto leva à hipotensão intracraniana, consequente vasodilatação e tração de estruturas nervosas, estabelecendo o quadro doloroso típico que piora em posição ortostática e melhora ao repouso. O diagnóstico de CPPD é clínico, e o quadro típico da dor é a principal evidência. Fatores de risco como pertencer ao sexo feminino, ser adulto jovem, gestante, história prévia de CPPD, maior calibre da agulha e/ou bisel cortante são descritos na literatura. A conduta terapêutica varia de acordo com a gravidade da dor, podendo ser conservadora ou ser realizado o "blood patch" (oclusão do orifício dural via administração local de sangue autólogo). O bloqueio bilateral do nervo occipital, guiado por ultrassom, e o bloqueio do gânglio esfenopalatino são intervenções analgésicas alternativas, porém, apenas o "blood patch" tem evidências científicas suficientes para ser recomendado como rotina terapêutica, ainda que não seja isento de complicações. Visto que os recursos terapêuticos são limitados, ensaios clínicos maiores são necessários para que formas robustas de tratamento para CPPD sejam possibilitadas.

Descritores: Cefaleia Pós-Punção Dural; Anestesia; Medula Espinal. 


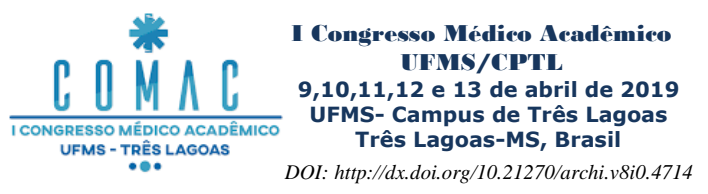

\section{CONTRIBUIÇÃO GENÉTICA PARA O ENTENDIMENTO DA FISIOPATOLOGIA DA DOENÇA DE CROHN}

Insfran, L.F.L.; Fonseca, A.G.; Carvalho, G.B.A.; Caldeira, J.C.V.; Couto, P.R.R.; Belini-Junior, E. luis.fernando.ufms@gmail.com

Universidade Federal de Mato Grosso do Sul - Campus de Três Lagoas

Categoria: Pôster

A Doença de Crohn (DC) integra o grupo das doenças inflamatórias intestinais (DII) e apresenta aspectos multifatoriais, os quais dificultam a correta compreensão de sua fisiopatologia. Apesar de forte componente genético de susceptibilidade, com mais de 200 loci associados, esse fator explica 1/3 dos eventos, abrindo possibilidades para outros fatores. A partir disso, objetivou-se avaliar a relação entre a genética, fisiopatologia e a ocorrência da DC. Foi realizada uma revisão bibliográfica com a base de dados PubMed e descritores: Crohn's disease, physiopathology, genetics. A busca envolveu artigos publicados nos últimos 5 anos e dentre os 26 artigos, 12 foram selecionados para leitura integral de acordo com os critérios de inclusão e exclusão. Dentre os distúrbios genéticos associados a etiologia complexa da DC, destaca-se: redução de peptídeos intestinais com função de barreira antimicrobiana, desenvolvimento de microbiana pró-inflamató $\mathrm{r}$ io, polimorfismos nos genes NOD2, ATG16L1 e IRGM relacionados à autofagia e miRNAs desregulados (ex: mir16, mir19b e mir21). Tais fatores contribuem para o estado inflamatório do trato gastrointestinal e possivelmente para a carcinogênese. Têm sido encontrados padrão de metilação específico na DC com 50 locais de metilação alterada e genes relevantes do sistema imune adaptativo e inato (MAPK13, FASLG, PRF1, S100A13, RIPK3 e IL-21R) associados a patogênese das DII. Conclui-se que as produções científicas dos últimos 5 anos resultaram em avanços relevantes para a compreensão da fisiopatologia da DC, mas sua etiologia e patogênese, apesar das diversas teorias propostas, permanecem desconhecido e muitos aspectos ainda precisam ser investigados.

Descritores: Doença de Crohn; Genética; Fisiopatologia. 


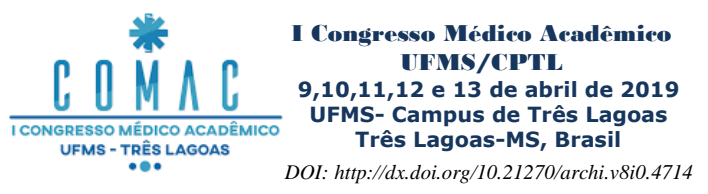

\section{DOENÇA DE TAY-SACHS E SUAS ESTRATÉGIAS TERAPÊUTICAS}

Albuquerque, A.S.; Pimenta, A.S.; Castro, G.D. ; Gomes, G.R.; Ferrareto, N.S.; Belini-Júnior, E. alycealbuquerque5@gmail.com

Universidade Federal de Mato Grosso do Sul - Campus de Três Lagoas

Categoria: Pôster

A doença de Tay-Sachs (DTS) é uma glangliosidose (subtipo GM2) caracterizada por neurodegeneração progressiva de caráter autossômico recessivo. As mutações no gene beta-hexosaminidase (HEXA) prejudicam a degradação do beta-N-acetil-hexosamino e do metabolismo gangliosídeo GM2 com consequências graves no sistema nervoso central (SNC). Ocorre ativação da micróglia e astrócitos com concomitante produção de mediadores inflamatórios, desencadeando inibição da formação de mielina e perda desta pré-existente. Diante da gravidade neurológica que acomete o portador, diferentes estratégias terapêuticas têm sido estudadas para a DTS.O objetivo do estudo foi analisar as estratégias terapêuticas testadas em estudos experimentais no tratamento da DTS.A revisão sistemática abrangeu 25 artigos selecionados a partir de 177 documentos obtidos na base de dados PubMed, com base em exclusão por análise de resumos e leitura dos documentos, sem um período específico determinado. Os descritores foram "Tay-Sachs", "genetics" e "therapy". Entre os periódicos estudados, 11 artigos ressaltam a terapêutica gênica por adenovírus, experimental em camundongos, na qual a inoculação intracraniana de vetores virais com genes codifica partes da beta-hexosaminidase e genes que aumentam a expressão e distribuição dessa enzima. Tal método induz atividades supranormais de HEXA com expressão difundida e de longa duração pelo cérebro e pela medula espinhal. Assim, a melhora neurológica foi acompanhada pela redução do depósito de gangliosídeo e da resposta imune; porém esta só é possível quando a terapia foi expressa antes do aparecimento da doença ou precocemente. Nenhum estudo demonstrou a cura efetiva da DTS. Entre as terapias, destaca-se: substituição enzimática, transplante de medula óssea, aprimoração enzimática, redução de substrato e infusões celulares.

Descritores: Doença por Armazenamento de Lisossomo no Sistema Nervoso; Genética; Tratamento Biológico. 


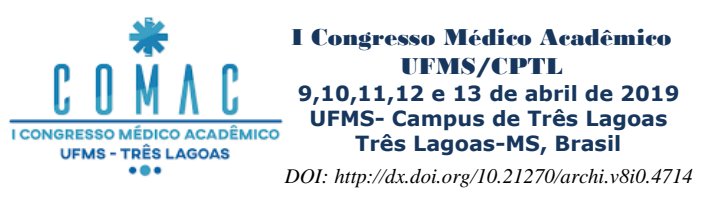

\section{EDUCAÇÃO EM SAÚDE NA ESCOLA SOBRE SUICÍDIO E DEPRESSÃO: UM RELATO DE EXPERIÊNCIA}

Montalvão, G. H. M. R.; Bernardes, G. B. V.; Cesar, G. H.; Bizinotto, G. B. A.; Pessalacia, J. D. R. gustavohmrm@gmail.com

Universidade Federal de Mato Grosso do Sul - Campus Três Lagoas

Categoria: Pôster

A adolescência é o estágio do desenvolvimento humano em que ocorrem modificações físicas e emocionais, caracterizando um período de conflitos e incertezas. Pensamentos suicidas são frequentes durante a transição para a adolescência devido aos problemas existenciais que surgem nessa etapa. Todavia, a ideação antecede o ato em si, sendo necessária a percepção precoce desses pensamentos e uma maior compreensão sobre suas causas. A experiência foi relata a partir das vivências de acadêmicos de Medicina em uma escola de ensino médio, ocorrendo por meio da implementação de vídeos, questionários e das dinâmicas 'O que te faz valer a pena', a qual pedia aos alunos que falassem sobre suas características, 'Motive o Colega' onde o aluno escrevia genericamente uma motivação para algum colega de sala, além do cartaz com o título 'O Que Te Motiva a Viver?', que foi deixado na escola para que eles o preenchessem. Dessa forma, com o intuito de aumentar o conhecimento sobre o assunto e a interação entre os alunos, fomentando a ajuda mútua entre eles. Percebemos, a partir da experiência, o quanto pequenas palavras e atitudes podem auxiliar pessoas que passam por momentos ruins. Nesse mesmo sentido, o julgamento e a crítica podem acentuar ainda mais sintomas já existentes. Vale acentuar o incalculável acréscimo acadêmico e psicológico da experiência ao grupo executor. $\mathrm{O}$ trabalho com jovens de baixa renda, em uma temática sensível, mostrou-nos que tais problemas não estão reclusos em segmentos sociais específicos e o quanto podem afetar o rendimento escolar dos adolescentes. Finalizamos esse projeto modificados e realizados, com a crença que a interação com os alunos e seus dilemas será fator determinante na nossa formação médica, estimulando o retorno para a sociedade, posteriormente, dos conhecimentos adquiridos por nós e moldando uma relação médico-paciente mais humana.

Descritores: Depressão; Suicídio; Saúde do Adolescente. 


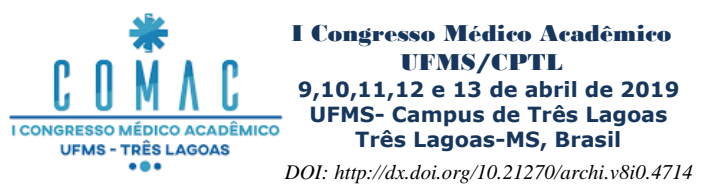

\section{EDUCAÇÃO EM SAÚDE NA ESCOLA SOBRE HIGIENE NA POPULAÇÃO RIBEIRINHA: UM RELATO DE EXPERIÊNCIA}

Ribeiro, S. Z.; Velone, N. C. I.; Bassler; T. C.; Pessalacia, J. D. R.

sabrina.zancani@hotmail.com

Universidade Federal de Mato Grosso do Sul - Campus de Três Lagoas

Categoria: Pôster

Introdução: A escola é um ambiente que proporciona a atuação de profissionais de saúde de maneira enriquecedora, possibilitando a promoção de saúde de forma a melhorar a qualidade de vida dos estudantes. A ação de educação em saúde nas escolas é um método que concede ao aluno a chance de aprender e tornar-se autônomo e ativo em seu aprendizado. Objetivo: Descrever a experiência de acadêmicos em uma ação de educação em saúde sobre importância da higiene para a prevenção de doenças. Método: Relato de experiência, fundamentado por ações de educação em saúde realizadas em outubro de 2018, em uma escola estadual no município de Três Lagoas/MS. Resultados: Os resultados evidenciaram o quão imprescindível foi a prática para moldar o conhecimento dos alunos acerca da temática, sendo perceptível que os déficits de cuidado com a higiene eram resultados da ausência de instrução e de uma perspectiva mais crítica sobre a gravidade acarretada pelas práticas inadequadas de higiene. Considerações finais: O desenvolvimento do trabalho nos permitiu ampliar conhecimentos como acadêmicas de Medicina. O ambiente escolar, sendo uma fonte de realidades heterogêneas, nos possibilitou agregar muito aprendizado acerca dos meios e formas que devemos promover saúde, prevenir e tratar doenças em nossos futuros campos de prática, de modo a propiciar exímio atendimento aos pacientes de acordo com o contexto e cenário o qual este está inserido.

Descritores: Serviços de Saúde Escolar; Prevenção de Doenças; Promoção da Saúde. 


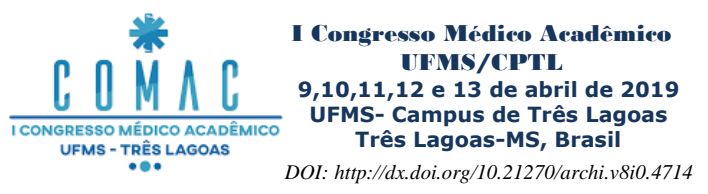

\section{EDUCAÇÃO EM SAÚDE PARA PREVENÇÃO DE GRAVIDEZ NA ADOLESCÊNCIA: UM RELATO DE EXPERIÊNCIA}

Souza, F. R.; Alves, A. M.; Bacciotti, B. P.; Pessalacia, J.D.R.

francielle_r.souza@hotmail.com

Universidade Federal de Mato Grosso do Sul - Campus de Três Lagoas

Categoria: Pôster

Introdução: A adolescência refere-se a um período de grandes descobertas e profundas transformações. A gravidez nessa etapa da vida acarreta diversas consequências biopsicossociais. No Brasil, a gravidez precoce é apontada como a causa majoritária de mortalidade entre adolescentes de 15 a 19 anos. Já na esfera municipal, verificou-se a partir do Sistema de Informações Sobre Nascidos Vivos (SINASC), diversos nascidos vivos de mãe com idade entre 10-19 anos no ano de 2016 em Três Lagoas-MS, demonstrando grande importância na tentativa de mudança do cenário atual. Objetivo: relatar a experiência de acadêmicos de Medicina em uma atividade de educação em saúde na escola. Método: Trata-se de um relato de experiência, a partir de uma atividade de educação em saúde para alunos do Ensino Fundamental, visando aprimorar o conhecimento sobre educação em saúde na escola e sobre a temática abordada. Resultados: A experiência proporcionou grandes benefícios para o desenvolvimento profissional do acadêmico, possibilitando contato com a população e contribuindo para uma melhor desenvoltura em público e métodos para lidar com os desafios. Ademais, viabilizou o crescimento como futuros profissionais de saúde, os quais devem aprimorar a escuta, estreitar vínculos com o jovem, garantir acesso a informações e aos métodos contraceptivos, e desenvolver ações coletivas que auxiliem os adolescentes a lidarem com sua sexualidade e desenvolverem autocuidado. Conclusão: Ressalta-se a importância de os currículos de Medicina contemplarem conteúdos e práticas voltados para a temática da Educação em Saúde na Escola, com vistas ao desenvolvimento de habilidade e competências profissionais para a assistência integral à saúde do adolescente.

Descritores: Educação Sexual; Sexualidade; Gravidez na Adolescência; Educação de Graduação em Medicina. 


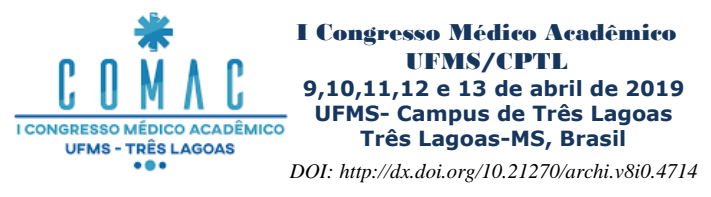

\author{
EDUCAÇÃO EM SAÚDE SOBRE GRAVIDEZ NA ADOLESCÊNCIA: UM RELATO DE \\ EXPERIÊNCIA \\ Junior, S.C.; Gaban, N.G.; Melo, T.M.; Pessalacia, J.D.R. \\ scjunior2008@hotmail.com \\ Universidade Federal de Mato Grosso do Sul - Campus de Três Lagoas MS. \\ Categoria: Pôster
}

Introdução: Durante a adolescência, os indivíduos sofrem diversas modificações biológicas e psicossociais, as quais influenciam diretamente no âmbito de sexualidade. Nesse ínterim, a educação em saúde torna-se uma ferramenta imprescindível de empoderamento e conscientização para os jovens. Objetivo: Relatar a experiência de estudantes de medicina em uma ação educativa de promoção em saúde sobre gravidez na adolescência em uma escola de ensino médio. Metodologia: Relato de Experiência a partir das vivências de acadêmicos de Medicina voltadas para a Educação em Saúde na temática Gravidez na Adolescência, em uma escola estadual de ensino fundamental e médio de Três Lagoas, MS. Resultados: Por meio de teatralizações e rodas de conversa, objetivou-se expandir o conhecimento dos escolares a partir do contato com os universitários No decorrer da atividade, foram problematizadas quatro perspectivas sobre a temática - informação, família, pontos de vista da maternidade e da paternidade. Sendo assim, desenvolveram-se discussões que propiciaram aprendizados e destituíram preconceitos entre os adolescentes, tornando a experiência muito gratificante para os acadêmicos envolvidos. Conclusão: $O$ projeto estabelecido constatou a necessidade e a importância da educação sexual no ambiente escolar, à medida que as atividades empreendidas efetivaram-se entre os jovens trabalhados e ainda permitiram uma melhor formação médica para os universitários incluídos.

Descritores: Adolescente; Sexualidade; Vulnerabilidade Social. 


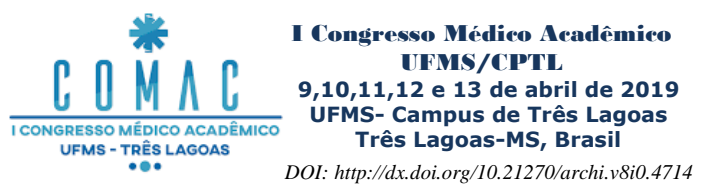

\section{EDUCAÇÃO EM SAÚdE SOBRE PARASITOSES EM UMA ESCOLA INSERIDA EM COMUNIDADE RIBEIRINHA: UM RELATO DE EXPERIÊNCIA}

Santana, M. P.; Figueiredo, N. M.; Carrijo, M. F.; Bassler, T. C.; Pessalacia, J. D. R.

marianadpsantana@gmail.com

Universidade Federal de Mato Grosso do Sul - Campus de Três Lagoas

Categoria: Pôster

Diante de uma concepção ampla do processo saúde-doença e de seus determinantes, a promoção da saúde surge como um recurso de capacitação da população que visa atingir a meta de bem estar individual e coletivo com a melhoria da qualidade de vida e saúde. Nesse contexto, através do conhecimento do perfil epidemiológico e socioambiental da comunidade contemplada com as ações em saúde, as medidas educacionais nas escolas é uma ferramenta necessária para prevenir a instalação e agravos de certas doenças. Esse estudo trata-se de um relato de experiência sobre um trabalho desenvolvido com grupos de crianças em uma escola às margens do Rio Paraná. O objetivo foi proporcionar educação em saúde aos estudantes, visando acrescentar conhecimento à vida dos mesmos para que possam prevenir episódios de parasitoses intestinais. Participaram dos grupos 64 alunos de ambos os sexos, de faixa etária entre 11 e 14 anos. As reuniões para planejamento do tema e as experiências em sala de aula ocorreram no mês de outubro de 2018. Foram realizadas duas aulas que retrataram o curso de doenças solicitadas pelo diretor da escola: ascaridíase e bicho geográfico. Foi palestrado a respeito dos sintomas e características específicas das doenças e seus parasitos, além da forma de controle das parasitoses correlacionada com medidas de higiene como principal forma de profilaxia. A estratégia utilizada foi participativa com metodologia ativa, associada a recursos didáticos como um boneco anatômico e microscópio. Os termos técnicos e médicos foram decodificados para a linguagem popular e acessível. Baseando-se nos temas abordados nas aulas, os alunos confeccionaram um jornal educativo, o que validou a compreensão e entendimento do conteúdo. A experiência proporcionou o conhecimento das necessidades dos grupos e planejamento de orientações compreensíveis e significativas para as crianças.

Descritores: Crianças; Doenças Parasitárias; Saúde Escolar. 


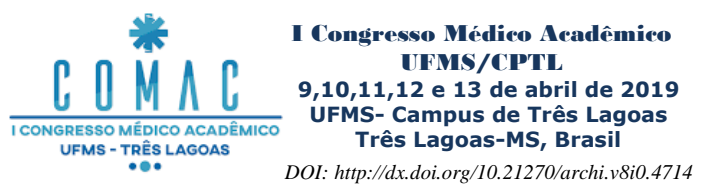

\section{EFEITO DO EXTRATO BRUTO HIDROETANÓLICO DA AROEIRA (SCHINUS TEREBINTHIFOLIUS RADDI) SOBRE A MUCOSA E CRIPTAS INTESTINAIS DE RATOS DIABÉTICOS}

Martins, S.R.; Uliana, C.H.

sanrogermartins@yahoo.com.br

Universidade Federal de Mato Grosso do Sul - Campus de Três Lagoas

Categoria: Pôster

Introdução: O Diabetes mellitus (DM) é um grupo heterogêneo de distúrbios metabólicos caracterizados por hiperglicemia crônica, decorrente de defeitos na ação e/ou secreção da insulina. A espécie Schinus terebinthifolius, popularmente conhecida como aroeira possui propriedade antioxidante, podendo ser uma alternativa na redução do estresse oxidativo no DM. Objetivo: Avaliar o efeito do extrato bruto hidroetanólico $(\mathrm{EBH})$ de Schinus terebinthifolius Raddi sobre a mucosa e criptas intestinais de ratos diabéticos. Método: Foram utilizados 16 Rattus norvegicus com 90 dias de idade, distribuídos aleatoriamente em: grupo normoglicêmico $(\mathrm{N})$, grupo normoglicêmico tratado com EBH de Schinus terebinthifolius (NA), grupo diabético induzido pela estreptozootocina (D) e grupo diabético induzido pela estreptozootocina e tratado com EBH de Schinus terebinthifolius (DA). Após 60 dias, os animais foram mortos e o cólon ascendente retirado, submetido à rotina histológica para obtenção de cortes transversais utilizados para análise da mucosa, profundidade e largura das criptas. Os procedimentos foram previamente aprovados pelo Comitê de Ética em Experimentação Animal. Resultados: O DM não promoveu alterações na mucosa intestinal. Houve redução significativa da mucosa e redução na profundidade das criptas apenas no grupo NA $(\mathrm{p}<0,05)$. No entanto a largura das criptas aumentou no grupo D em relação ao grupo N. Não houve diferença significativa entre o grupo D e DA (p>0,05). Conclusão: Possivelmente o EBH atuou como pró-oxidante, lesando DNA, proteínas e lipídios promovendo atrofia da mucosa e redução na profundidade das criptas no grupo NA. Esses achados sugerem que a utilização da planta em indivíduos hígidos deve ser avaliada com cautela, pois pode resultar no desenvolvimento de complicações gastrointestinais que precisam ser investigadas.

Descritores: Diabetes; Mucosa; Intestino. 


\section{EFEITOS DA EXPOSIÇÃO MATERNA AO PARABENO E FTALATO SOBRE O DESENVOLVIMENTO REPRODUTOR DA PROLE MASCULINA}

Silva, H.G.; Cleto, P.E.H.; Costa, W.F.; Nunes, T.D.A.M.; Erthal, R.P.; Punhagui, A.N.F.; Fernandes G.S.A.; Guerra M.T.

hiiarasilva@gmail.com

Universidade Federal de Mato Grosso do Sul - Campus de Três Lagoas

Categoria: Pôster

Parabenos e ftalatos são utilizados na indústria cosmética, farmacêutica e alimentícia e são considerados desreguladores endócrinos. O objetivo deste trabalho foi avaliar os efeitos da exposição simultânea ao parabeno e ftalato sobre o desenvolvimento do sistema reprodutor de prole masculina de ratos. Ratas prenhes Wistar foram divididas em seis grupos: controle gavage $(n=6)$, que recebeu o veículo (óleo de milho) via oral; controle subcutâneo $(n=6)$ que recebeu o veículo via subcutânea (s.c.); controle gavage + subcutâneo $(\mathrm{n}=5)$ exposto ao veículo vias oral e s.c.; butilparabeno (BP, $\mathrm{n}=7)$ recebeu $100 \mathrm{mg} / \mathrm{kg}$ via s.c.; Di(2-etilhexil)ftalato (DEHP, $\mathrm{n}=5$ ) recebeu $500 \mathrm{mg} / \mathrm{kg}$ via oral; e grupo BP+DEHP ( $\mathrm{n}=8$ ), exposto simultaneamente a $100 \mathrm{mg} / \mathrm{kg}$ BP s.c. e $500 \mathrm{mg} / \mathrm{kg}$ DEHP, via oral. Estas doses são consideradas LOAEL para o sistema reprodutor de roedores. $\mathrm{O}$ tratamento ocorreu do dia gestacional 12 até o final da lactação e os seguintes parâmetros foram avaliados na prole masculina: distância anogenital e peso no dia pós-natal (DPN) 1, número de mamilos e peso no DPN 13, instalação da puberdade a partir do DPN 30 e peso de órgãos reprodutores no DPN 90. Os filhotes expostos ao BP+DEHP tiveram um menor peso no DPN 1; os demais parâmetros, entretanto, não apresentaram alterações significativas. Podemos concluir que, nestas condições experimentais, a exposição simultânea ao parabeno e ftalato não foi capaz de alterar o desenvolvimento sexual da prole masculina de ratos.

Descritores: Disruptores Endócrinos; Parabenos; Dietilexilftalato. 


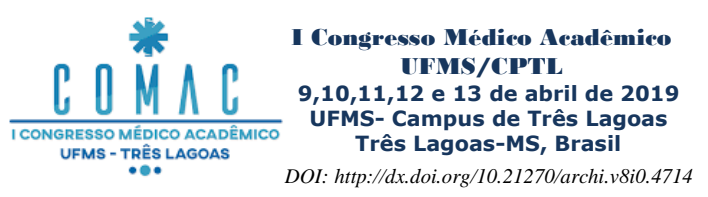

\title{
EFICÁCIA DO PLASMA RICO EM PLAQUETAS (PRP) NA MELHORA DA CICATRIZAÇÃO E NA DIMINUIÇÃO DE COMPLICAÇÕES PÓS-OPERATÓRIAS: UMA REVISÃO INTEGRATIVA DE LITERATURA
}

\author{
Santos, I.R.; Cesar, G.H.; França, V.O.; Silva, L.A; Ribeiro, A.M.F; Guerra, M.T. \\ santosrezendeisabella@gmail.com \\ Universidade Federal de Mato Grosso do Sul - Campus Três Lagoas \\ Categoria: Pôster
}

O plasma rico em plaquetas (PRP) é um concentrado autólogo enriquecido com quantidades elevadas de plaquetas, em comparação com o sangue total, obtido após centrifugação do sangue e a separação de hemocomponentes. É utilizado em vários procedimentos por conter $\alpha$-grânulos, fibrinogênio e fatores de crescimento, importantes no processo de cicatrização. O estudo da utilização do PRP em feridas cirúrgicas é relevante devido ao alto número de complicações por dificuldades na cicatrização, sangramentos intensos e infecções. O objetivo do artigo é sintetizar a literatura existente sobre o uso do PRP na otimização da cicatrização de feridas cirúrgicas, reduzindo a incidência de complicações pósoperatórias. A base de dados selecionada para a seleção dos artigos foi a Biblioteca Virtual em Saúde (BVS), com critérios de inclusão: texto completo disponível, MEDLINE, idioma inglês e espanhol, publicações de 2010 a 2019 e artigo como único tipo de documento. Foram encontradas 18 publicações, que foram submetidas a critérios de exclusão, restando 8 artigos. Para a coleta de dados foi utilizado o instrumento da URSI, validado e adaptado para o estudo. Os artigos foram divididos em três categorias analíticas com base no tipo de participante do estudo, sendo: estudo com humanos (A2, A4, A5, A6, A7, A8), coelho (A1) ou rato (A3). Os artigos elencados mostram resultados com o uso do PRP, como diminuição da inflamação e menores períodos de hospitalização, resultados de uma melhora cicatricial. Baseado nesses estudos, pode-se afirmar empiricamente a eficácia do PRP. Esta otimização, porém, depende de fatores como o tipo tecido, a extensão da lesão e o tipo de cirurgia realizada. Por fim, a escassez de estudos clínicos comprovatórios sobre o uso do PRP torna precipitada qualquer conclusão sobre seus efeitos na melhora de cicatrização e redução de complicações pós-operatórias.

Descritores: Plasma Rico em Plaquetas; Cicatrização; Complicações Pós-Operatórias. 


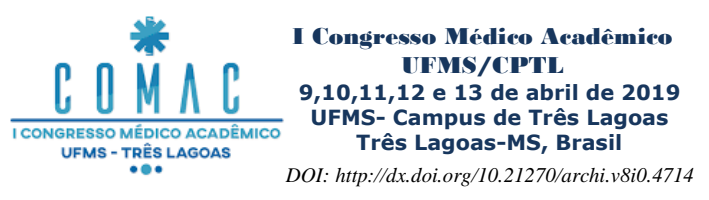

\section{EPILEPSIA MIOCLÔNICA COM FIBRAS VERMELHAS RASGADAS (MERRF) - REVISÃO DE UMA SÍNDROME DO DNA MITOCONDRIAL}

Alves, I. F.; Godas, A.G.L.; Batista, R.; Cintra, G. S.; Xavier, A. C.; Belini-Junior, E. izamila1@hotmail.com

Universidade Federal do Mato Grosso do Sul - Campus de Três Lagoas

Categoria: Pôster

A Epilepsia mioclônica com fibras vermelhas rasgadas (MERRF) é um distúrbio mitocondrial caracterizado por mioclônia, epilepsia, ataxia e miopatia. Ocorre principalmente devido a uma mutação no mtDNA, associada a uma disfunção no sistema de fosforilação oxidativa da mitocôndria alterando funções neuronais e musculares. A revisão integrativa abordou os principais genes que sofrem mutações, as principais características clínicas e possíveis tratamentos, por meio das bases de dados PUBMED/MEDLINE, de 12/2014 à 12/2018, utilizando os seguintes descritores: MERRF; Genetics e Mutation. Apenas artigos em inglês e estudos clínicos foram selecionados para este trabalho. Após a leitura dos resumos dos 40 artigos, selecionou-se 14 para a composição deste estudo. Desses, 85,7\% apresentaram a mt.8344A > G, sendo esta a mutação clássica para a síndrome MERRF, 21,42\% observaram a mutação mt.8356T > C, mt.8363G > A, 8363G > A, presentes também na MERRF, e $21,42 \%$ trouxeram mutações raras para MERRF $(\mathrm{mt} .8361 \mathrm{G}>\mathrm{A}$, mt.14709T > C e mt.15923A > G). $71,4 \%$ dos artigos trouxeram como principal característica clínica para MERRF a fraqueza e atrofia muscular, seguida de epilepsia e convulsões correspondendo a 50\%, problemas ópticos/auditivos em $35,7 \%$ e problemas respiratórios em $21,4 \%$. Apenas $28,5 \%$ dos artigos trouxeram terapias, sendo 7,14\% que preconizou o tratamento dos sintomas e $21,7 \%$ que trabalharam com engenharia genética para correção da mutação mt. 8344A > G. Conclui-se que ao afetar o gene que codifica o tRNA mitocondrial ocorre falha na produção de certa proteína mitocondrial, porém nem todas as mitocôndrias são afetadas e as pessoas não são afetadas com igual gravidade. A MERRF precisa ser diagnosticada o mais rápido possível a fim de melhorar a qualidade de vida do paciente, uma vez que não possui cura.

Descritores: Síndrome MERRF; Genética; Mutação. 


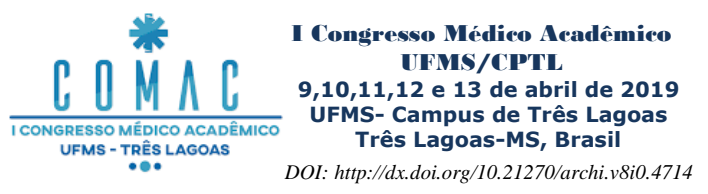

\section{EXPERIÊNCIA ACADÊMICA SOBRE ATIVIDADE PONTUAL DE EDUCAÇÃO EM SAÚDE NA REDE PÚBLICA DE ENSINO EM TRÊS LAGOAS - MS}

Leão, C.L.S.; Carrijo, M.F.; Souza, T.G.B.; Pessalacia, J.D.R.

carlalsleaoufms@gmail.com

Universidade Federal do Mato Grosso do Sul - Campus de Três Lagoas

Categoria: Pôster

Introdução: A escola é um dos cenários em que os profissionais de saúde podem trabalhar visando à promoção da saúde. Nesse contexto, a abordagem de atividades por meio da metodologia ativa permite que os alunos sejam elementos no processo de ensino aprendizagem ao promover sua autonomia e criticidade perante o assunto apresentado. Objetivo: Relatar a experiência de acadêmicas em uma ação de Educação em Saúde na Escola na temática das Infecções Sexualmente Transmissíveis (IST). Método: Relato de experiência escrito com base nas vivências de acadêmicas de Medicina em uma escola pública estadual do município de Três Lagoas/ MS, no mês de agosto de 2018. Resultados: A atividade foi realizada em quatro turmas diferentes no período vespertino e respeitou tanto os recursos humanos quanto a realidade local. A abordagem dinâmica foi fundamentada através do material do Programa Saúde na Escola sobre saúde reprodutiva e lidou, por meio de discussões sobre as IST, com assuntos que envolvem diversos tabus, desmistificando determinados conceitos por meio do 'Quiz das IST'. Grupos foram formados entre os alunos em que cada equipe respondia e justificava as perguntas feitas durante a oficina e, após os alunos elaborarem suas respostas, as acadêmicas sanavam as dúvidas que surgiam. Perante a visão das alunas de medicina sobre a atividade desempenhada, obtiveram-se resultados positivos em que a oficina foi classificada como enriquecedora. Conclusão: A atividade desempenhada se faz essencial em ambiente escolar devido ao incentivo do protagonismo dos discentes, além de ajudar o corpo docente do colégio na abordagem de assuntos através do conhecimento transmitido pelas universitárias. Ademais, as acadêmicas precisam trabalhar com a comunidade a fim de atuarem, no momento de exercer a sua prática profissional, de forma eficaz com a população sobre assuntos como as IST.

Descritores: Educação em saúde; Metodologia; Doenças Sexualmente Transmissíveis. 


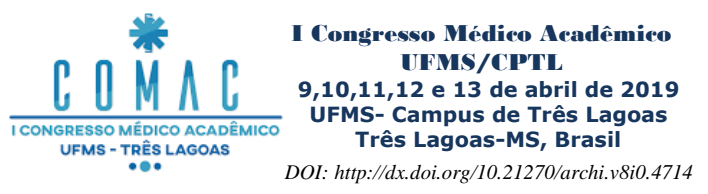

\author{
FOTOTERAPIA NA OSTEOATRITE DE JOELHO - REVISÃO DE LITERATURA \\ Xavier, A.C.; Cintra, G.S.; Godas, A.G.L.; Corazza, A.V. \\ alexxavierjudo@gmail.com \\ Universidade Federal do Mato Grosso do Sul - Campus de Três Lagoas \\ Categoria: Pôster
}

A osteoartrite (OA) é caracterizada por danos na cartilagem, modificações do osso subcondral, síntese de osteófitos, inflamação do tecido sinovial e do tendão, além de fraqueza muscular rigidez articular e quadro álgico. O joelho é a articulação com maior incidência de osteoartrite e vários recursos físicos não invasivos são utilizados para o tratamento conservador, destacando a fototerapia de baixa potência. $\mathrm{O}$ objetivo deste estudo foi avaliar se existe melhora dos pacientes com OA de joelho na utilização da fototerapia com Laser, em relação aos principais parâmetros utilizados. Esta revisão integrativa abordou o tratamento da OA de joelho por meio do uso da fototerapia através da base de dados PUBMED/MEDLINE, de 01/2017 a 12/2018, utilizando os descritores: Osteoarthrit; Knee; Laser; Phototherapy. Todos os artigos utilizados foram de estudos clínicos em humanos, com artigos em inglês. Identificou-se 22 artigos e após, 6 se relacionavam com o tema proposto. Destes verificou-se que 16,66\% foram de tratamentos exclusivamente com o uso de laserterapia, os demais tiveram associação com exercícios de fortalecimento, uso de analgésicos, seleção de pontos da acupuntura e utilização dos efeitos sinérgicos do ultrassom. Evidenciou-se que $83,34 \%$ utilizaram modo pulsado de emissão e os demais utilizaram a onda contínua. Além disso, todos os comprimentos de onda foram utilizados no espectro infravermelho, entre 808 e $1064 \mathrm{~nm}$, sendo utilizado em 50\% dos casos 904nm. Conclui-se que a utilização da laserterapia de baixa potência para o tratamento da OA de Joelho gera aumento de betaendorfina e uma redução na substância $\mathrm{P}$, gerando efeitos anti-inflamatórios, analgésicos, aumento da função física da articulação e melhora da qualidade de vida do paciente sendo associado ou não com outra forma de terapia.

Descritores: Joelho; Laser; Fototerapia. 


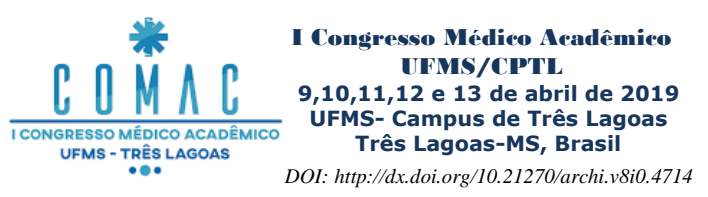

\section{FUNCIONALIDADE DO IDOSO NOS DIVERSOS SETORES DA SAÚDE: UMA REVISÃO INTEGRATIVA}

Bernardes, G.B.V.; Rodrigues,G.H.M.; Cesar,G.H.; Lima, L.G.F.C.; Bizinotto,G.B.A.; Pessalacia, J.D.R. Instituição: Universidade Federal de Mato Grosso do Sul - Campus de Três Lagoas gabrielbvb@gmail.com.

Categoria: Pôster

Introdução: No Brasil, o envelhecimento populacional desencadeia problemas de saúde que desafiam o sistema de saúde, a previdência social e ainda há a negligência à figura do idoso. Assim, é fundamental discorrer acerca dessa população alvo e do envelhecimento, abordando os setores de saúde. Objetivo: Analisar na literatura as publicações sobre a temática funcionalidade do idoso nos setores da saúde. Metodologia: Revisão integrativa de literatura. Descritores: 'idoso' [and] 'saúde do idoso' [and] 'classificação Internacional de Funcionalidade, Incapacidade e Saúde'. Foram inclú́dos artigos em português e inglês, disponíveis nas bases Scientific Electronic Library Online (SciELO) e Literatura Latino-americana e do Caribe em Ciências da Saúde (LILACS), dos anos de 2009 a 2017 e que tratem sobre a temática de estudo. A questão norteadora foi: 'Quais estudos abordam a temática da funcionalidade dos idosos nos diversos setores de saúde?'. Resultados: Identificou-se 9 artigos que atendiam os critérios de inclusão. A partir desses artigos, emergiram duas categorias temáticas: 'Benefícios do uso da CIF (Classificação Internacional de Funcionalidade, Incapacidade e Saúde) para a prática profissional' e 'Outros instrumentos na avaliação da funcionalidade do idoso'. Nesse contexto, destacou-se a condição funcional do idoso no âmbito hospitalar e institucional e produções com o objetivo de compreender o cuidado ao idoso. Conclusão: Evidenciou-se a importância da atuação profissional na manutenção e revitalização da capacidade funcional do idoso. Além disso, destacou-se a importância da CIF e outras classificações na prática profissional, onde consegue-se identificar as necessidades básicas afetadas e elaborar um plano de cuidado com enfoque para o envelhecimento ativo.

Descritores: Saúde do Idoso; Serviços de Saúde; Classificação Internacional de Funcionalidade; Incapacidade e Saúde. 


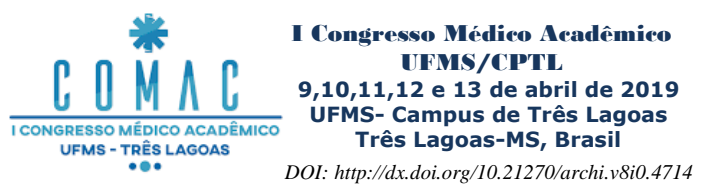

\section{GENES CANDIDATOS ENVOLVIDOS NO DESENVOLVIMENTO DA ESCLEROSE LATERAL AMIOTRÓFICA}

Silva, B. F; Oliveira, B. F.; Frisene, D.; Silva, J. P. B¹. Silva, M. V. A.; Belini - Junior, E. brunoferreiracoro@gmail.com Universidade Federal do Mato Grosso do Sul - Campus de Três Lagoas

Categoria: Pôster

Esclerose lateral amiotrófica (ELA) é uma doença neurodegenerativa caracterizada pela morte de neurônios motores do encéfalo, tronco cerebral e medula espinhal resultando em fraqueza muscular e eventual paralisia. Diante de multifatores associados a etiologia da ELA e a quantidade de informações disponíveis sobre o assunto, o objetivo do estudo foi identificar e analisar genes candidatos envolvidos na ELA para auxiliar na compreensão do desenvolvimento da doença. Trata-se de uma revisão integrativa com a questão norteadora: quais genes candidatos envolvidos no desenvolvimento da ELA? Foram utilizadas as bases de dados BVS e MEDLINE com os descritores "Gene", "Esclerose Lateral Amiotrófica" e "Genética" em todos idiomas. De 2014 a 2019, identificou-se 27 artigos e após leitura dos resumos, 9 se correlacionavam à temática proposta. Nenhuma causa genética isolada foi responsável pela ELA, no entanto, alguns genes estão associados com a doença. Mutações no gene SOD1 (favorece o estresse oxidativo e leva à degeneração neuronal); a repetição G4C2 no gene $C 9 O R F 72$ (resulta na perda da função da proteína C9orf72, importante para o desenvolvimento neuronal e associada a demência frontotemporal); mutações no gene TARDBP (diminuição da proteína TDP-43 ligada na atividade sináptica, crescimento neuronal e integridade dendrítica e axonal); mutação no gene $S E T X$ (diminuição da senataxina, proteína tipo helicase, impede a expressão de genes em neurônios); e mutações no gene UBQL2 (perde a função da ubiquilina 2 e as proteínas ubiquitinadas acumulam nos neurônios motores afetando sua integridade). As evidências demonstraram que os genes devem ser analisados em conjunto para a obtenção de associações expressivas na ELA. A busca de genes permite elucidar vias moleculares responsáveis pela doença e abrir novos caminhos para possíveis alvos terapêuticos.

Descritores: Biomarcadores Genéticos; Esclerose Lateral Amiotrófica; Variantes Genéticas. 


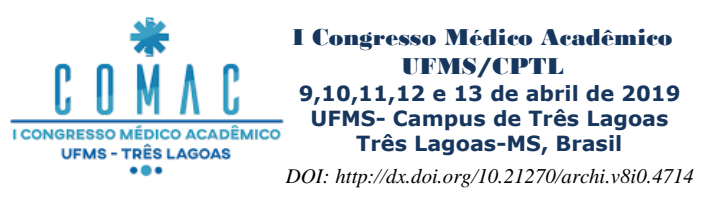

\section{IDENTIFICAÇÃO DE VARIANTES GENÉTICAS ASSOCIADAS COM A GRAVIDADE E A PROGRESSÃ O DA DOENÇA DE HUNTINGTON}

Cunha, P.H.B., Costa, F.P.R., Couto, S.B.; Araújo, T.N.; Machado, V.P.; Belini-Junior, E. pedrohbc150397@gmail.com

Universidade Federal do Mato Grosso do Sul - Campus de Três Lagoas

Categoria: Pôster

A Doença de Huntington (DH) é uma afecção neurodegenerativa, autossômica dominante, em que se observa perda de coordenação motora, alterações psiquiátricas e declínio cognitivo progressivos. Os primeiros sintomas e a gravidade da doença estão diretamente relacionados à expansão de repetições citosina-adenina-guanina (CAG) no gene huntingtina (HTT), que leva à síntese da huntingtina mutante. Essa condição causa a morte de neurônios específicos, disfunção dos circuitos cortico-estriatais e nigroestriatais Há conflitos na literatura entre a quantidade de repetições CAG no gene HTT com a progressão clínica da DH, pois há estudos que sugerem associação ambígua e até mesmo inexistente. Ainda assim, as manifestações clínicas, de toda ordem, ocorrem em pacientes com pelo menos 35 repetições CAG no gene HTT. Da mesma forma, há uma tendência em associar o comprimento das repetições com o padrão de conectividade estrutural em pacientes pré-manifestantes da doença, de modo que esse padrão seja dirigido pelas repetições CAG. A relação melhor expressa indica a interação dos alelos mutantes com o alelo normal, de modo que ainda em altas repetições do mutante, a suprarepetição do alelo normal atua reduzindo a gravidade clínica da doença. Independente da associação que se procura das repetições CAG do gene HTT na DH, realizar o diagnóstico para detectar pelo menos 35 repetições já é o suficiente para compreender as manifestações da DH.

Descritores: Doença de Huntington; Variação Genética; Índice de Gravidade da Doença. 


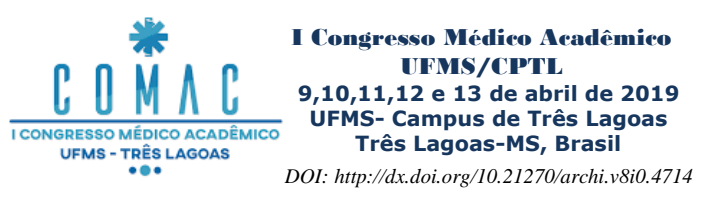

\section{IMPACTO DAS MUTAÇÕES NOS GENES RELACIONADOS À VIA SONIC HEDGEHOG NO DESENVOLVIMENTO DE HOLOPROSENCEFALIA}

Barbosa-Júnior, L.; Silva, M.R.; Daires, M.S.; Donato, R.S.; Moreira, S.; Belini-Junior,E. lindembergbarbosajunior@hotmail.com

Universidade Federal de Mato Grosso do Sul - Campus Três Lagoas.

Categoria: Pôster

A Holoprosencefalia (HPE; OMIM 236100) é uma malformação do cérebro que resulta da clivagem incompleta do prosencéfalo durante a embriogênese humana. Nessa fase, o gene Sonic Hedgehog (SHH) é expresso nos tecidos em desenvolvimento da linha média facial, sendo sua rede sinalizadora importante na formação craniofacial. Logo, a etiologia da HPE é influenciada por fatores genéticos (mutações e anomalias cromossômicas) e ambientais. O objetivo foi identificar a repercussão das mutações em genes relacionados a via do $S H H$ durante a gênese do prosencéfalo e da face medial que resultam em HPE. A metodologia utilizada para esta revisão de literatura ocorreu pela busca de artigos na base de dados PUBMED com os descritores Holoprosencefalia, Sonic Hedgehog, Anomalias Craniofaciais, e o operador AND. Foram selecionados os artigos publicados nos últimos 5 anos, completos e sem custo para o acesso. Totalizaram-se 10 artigos, sendo elegidos 8 , cujos genes estão diretamente relacionados a via de $S H H$. Como consequiência, foram identificados 16 genes que influenciam a via de $S H H$, resultando em alterações dos centros de sinalização que especificam e modelam tecidos circundantes. Essas alterações originam um amplo espectro fenotípico de HPE com alterações prosencefálicas como: alobar, lobar, semilobar e variante inter-hemisférica média; e craniofaciais como: microformas e formas graves. Foi descrito que mutações em um único gene da via de sinalização envolvendo $S H H$ nem sempre resultam no fenótipo de HPE, necessitando de uma segunda mutação ou fator ambiental para desencadear a alteração. Portanto, percebe-se que as mutações relacionadas aos genes da via do $S H H$ podem resultar em variados fenótipos de HPE, tendo essa patologia uma penetrância incompleta, o que dificulta o aconselhamento genético e o diagnóstico.

Descritores: Holoprosencefalia; Mutação; Anomalidades Craniofaciais. 


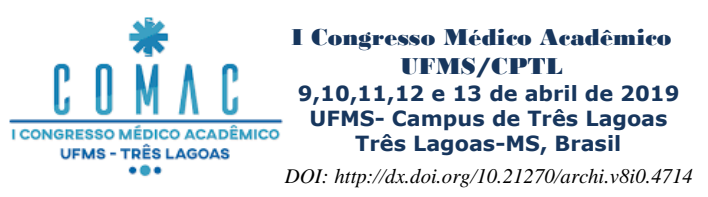

\section{IMPACTO DO DIAGNÓSTICO DO CÂNCER INFANTIL NA FAMÍLIA: ASPECTOS SOCIAIS}

Minomi, B. M.; Libório, L.M.; Afonso, B. E.; Puertas, M.V.; Vieira, J.S.; Costa, M.P.; Borges, S.L.C. brunaminomi@gmail.com

Universidade Federal do Mato Grosso do Sul - Campus de Três Lagoas

Categoria: Pôster

O câncer infantil acomete a faixa etária de 0 a 19 anos, sendo os tumores mais comuns a leucemia, o tumor de sistema nervoso central e os linfomas. Representam 3\% das neoplasias malignas na população segundo o Instituto Nacional de Câncer. Neste aspecto, a família do paciente adota uma função essencial para a obtenção de resultados positivos no decorrer do curso da doença, e sofre impactos prejudiciais nos âmbitos psicossocial e econômico. O objetivo desde trabalho foi determinar os impactos sociais do câncer infantil na vivência dos familiares diante do diagnóstico até a evolução da doença. Trata-se de um estudo prospectivo transversal, com observação direta extensiva, mediante a aplicação do questionário Pediatric Inventory for Parents - PIP, realizado em um hospital estadual no período de março a junho de 2017, realizado com 30 familiares de crianças com diagnóstico confirmado de câncer há três meses. Através do PIP, eram possíveis pontuações mínima e máxima de 14 e 70 pontos, tanto na variável frequência quanto na variável dificuldade em 14 questões que indicavam o nível de prejuízo social das famílias, sendo obtida frequência média de 48 pontos e dificuldade média de 39.5 pontos. Isso evidencia que o câncer infantil gera um impacto social relevante para os familiares, uma vez que a maior parte do tempo é direcionada aos cuidados dos pacientes. Sendo assim, a mudança de rotina acontece de forma brusca, pois a ida e permanência em hospitais é frequente, prejudicando a interação social, o próprio autocuidado e o lazer, gerando grande aumento de estresse emocional e físico aos familiares. Assim, é inegável que é preciso estimular a convivência social, visto que ameniza o impacto negativo na saúde mental e física dos cuidadores e principalmente, para que a assistência seja integral e efetiva ao infante, que é o principal objetivo da família e da equipe médica.

Descritores: Avaliação em Saúde; Impacto Social; Planejamento Social. 


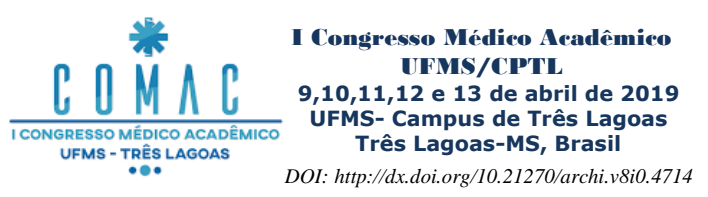

\section{IMPORTÂNCIA DAS MUTAÇÕES NO GENE CFTR PARA TERAPIA FARMACOLÓGICA NA FIBROSE CÍSTICA}

Campoville, A. H.; David, T. C.; Galvão, R. G.; Kamiyama, L. M.; Weis, M.; Belini-Junior, E. Universidade Federal de Mato Grosso do Sul - Campus de Três Lagoas amanyhatae@gmail.com

Categoria: Pôster

Fibrose cística (FC) é uma doença autossômica recessiva que atinge 1:7.576 nascidos-vivos no Brasil e com custo de tratamento aproximado de 30 mil reais/paciente/ano. As mutações do gene CFTR prejudicam a função da proteína de canal de íons de CL-e HCO3-, expressa em glândulas exócrinas, que produz secreções espessas favorecendo infecções, inflamação e fibrose. Mais de 2000 mutações do gene CFTR já foram descritas e são agrupadas em 7 classes conforme o defeito da proteína e podem ser utilizadas para alvos terapêuticos específicos. O estudo teve o objetivo de avaliar as terapias para a FC correlacionando com as classes de mutações. Foram selecionadas publicações de 2015 a 2019, na base de dados PubMed com os descritores "Cystic Fibrosis", "Drug Therapy", "CFTR mutations", obtendo 437 publicações, das quais 102 atendiam ao objetivo deste estudo. Para as mutações de classe I não há fármacos aprovados. As de classe II apresentam drogas corretoras, como o lumacaftor para homozigotos da mutação Phe508del. A classe III também tem drogas aprovadas, a exemplo do ivacaftor. Atualmente, para classes IV e V, não existem fármacos disponíveis. As mutações de classe VI, com menor instabilidade do canal, não possuem drogas estabilizadores homologados. Por fim, a classe VII, em que a proteína é irrecuperável, não há fármacos aprovados. Mesmo as terapias farmacológicas individualizadas já aprovadas como corretores e potencializadores, não são usados isoladamente, pois não são capazes de reverter o quadro clínico da FC. Ainda assim, as novas terapias, visando níveis celulares específicos em cada classe de mutação, são altamente relevantes e promissoras, uma vez que, podem eliminar a fonte primária dos defeitos de canal que geram as disfunções na FC.

Descritores: Fibrose Cística; Tratamento Farmacológico; Regulador de Condutância Transmembrana em Fibrose Cística. 


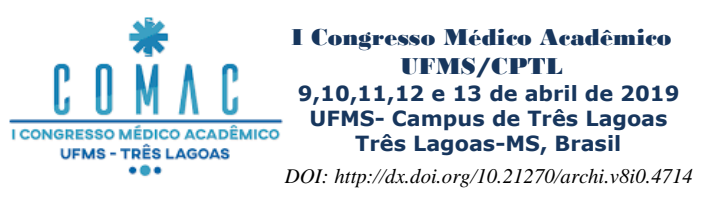

\section{INCLUSÃO ESCOLAR DE CRIANÇAS COM TRANSTORNO DO ESPECTRO AUTISTA}

Zago, T. O.; Tsukuda, L.; Sarubi, A.C.; Moraes, D.O.P.; Moreira, A. S. taiza_zago@hotmail.com

Universidade Federal de Mato Grosso do Sul - Campus de Três Lagoas

Categoria: Pôster

Denomina-se Transtorno do Espectro do Autismo (TEA) como uma desordem aguda do desenvolvimento e não como doença mental e tem sido detectado com maior frequência e cada vez mais cedo no Brasil. $O$ ensino estruturado é o meio facilitador mais eficaz para a "cultura do TEA". O objetivo deste trabalho foi analisar estratégias atuais e pano-ramas existentes para a inclusão escolar de crianças com TEA, visando um processo de inclusão eficiente, no qual o sistema educacional e social deve adaptar-se para receber a criança e poder amenizar o efeito dos déficits relacionados ao TEA e suas consequênci-as ao aprendizado. Esse trabalho foi executado na forma de revisão bibliográfica, a base de dados definida foi o PubMed e os descritores foram autism AND schoolinclusion AND children. Foram selecionados trabalhos que preencheram os requisitos: pesquisas que relacionam TEA e propostas, experiências ou relatos de inclusão escolar infantil, publicados entre 1995 e 2016. A maioria dos trabalhos apontava para benefícios e desa-fios na inclusão de autistas em escolas regulares, bem como a importância da sociabili-dade e boa convivência com pais, colegas e professores. Dentre os benefícios: o aprimo-ramento e desenvolvimento de habilidades criativas e intelectuais pelas crianças autis-tas, o estímulo à ampliação de suas capacidades, além de proporcionar às crianças não autistas a oportunidade de conviver com as diferenças. Os principais desafios foram a falta de conhecimentos e técnicas, a inadequação da grade curricular e a falta de comu-nicação entre família e educadores. Entende-se que a inclusão de crianças autistas em escolas regulares e o sucesso da sociabilidade requerem modificações comportamentais e educativas, de forma a potencializar suas habilidades e capacidades, não permitindo que a inclusão se torne excludente ou alheia a esse desenvolvimento.

Descritores: Autismo Infantil; Inclusão em Educação; Integração Escolar. 


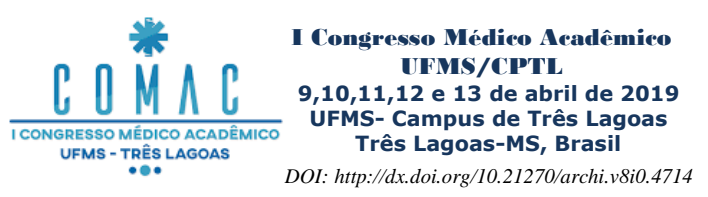

\section{INTOXICAÇÃO POR AGROTÓXICOS EM TRABALHADORES RURAIS: REVISÃO LITERÁRIA E NOTA PRÉVIA PARA UM ESTUDO NO MUNICÍPIO DE TRÊS LAGOAS (MS)}

Souza, L.C.; Alencar, T.S.; Soares, L.R.; Saraiva, K.V. de O.

souzacandidolara@gmail.com

Universidade Federal do Mato Grosso do Sul - Campus de Três Lagoas.

Categoria: Pôster

O Brasil está em primeiro lugar no ranking mundial de consumo de agrotóxicos, com 11 casos de intoxicação/dia e em $7^{\circ}$ lugar no uso por área plantada. Diante disso, iniciamos um estudo sobre a exposição dos agrotóxicos à saúde de trabalhadores rurais, com o objetivo de investigar efeitos dos agrotóxicos à saúde humana. Trata-se de uma revisão de literatura realizada de dezembro/2018 a março/2019, sendo uma nota prévia que expõe os resultados bibliográficos da fase inicial desta pesquisa, com coleta prevista para setembro de 2019 em Três Lagoas. Realizamos a busca nos portais Scielo.br e BVS, com as palavras-chaves: agrotóxico, pesticida e herbicida. Foram selecionados 36 artigos dos últimos dez anos e excluídos aqueles com foco na saúde ambiental. Os estudos evidenciam os efeitos da intoxicação por agrotóxicos organoclorados e organofosforados, sendo os principais: inapetência, cólicas abdominais, incontinência urinária e fecal, dispneia, tosse, lacrimejamento, salivação, sudorese, bradicardia e hipotensão, listados como manifestações muscarínicas, enquanto as nicotínicas foram: fasciculações, tremores, câimbras, paralisia muscular, taquicardia. As manifestações gerais no SNC foram: inquietação, labilidade emocional, cefaleia, sonolência, confusão mental, marcha descoordenada, depressão respiratória, hipotonia, convulsões e coma. Infertilidade, teratogenia, câncer. Doenças neurológicas, hepáticas, renais, respiratórias e imunológicas foram descritas na intoxicação crônica, além da hipótese do aumento de suicídios. Espera-se a partir desta primeira fase da pesquisa, investigar os efeitos dos agrotóxicos nos trabalhadores de Três Lagoas, colaborando para prevenir intoxicações e fornecer subsídios para políticas públicas de saúde voltadas para esses trabalhadores.

Descritores: Agroquímicos; Intoxicação por Organofosfatos; Prevenção Primária. 


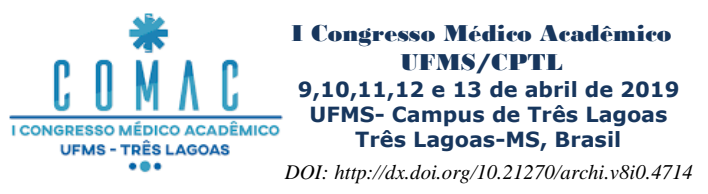

\section{LEVANTA E ANDA: PROJETO DE EXTENSÃO EM MEDICINA SOCIAL PARA REDUÇÃO DA VULNERABILIDADE DE ADOLESCENTES}

Freitas, G. dos S.G.F; Pereira Júnior, W. dos S.; Saraiva, K.V. de O. galdioliz@gmail.com

Universidade Federal do Mato Grosso do Sul - Campus de Três Lagoas

Categoria: Pôster

A evasão de alunos do ensino médio está em crescimento no Brasil, assim como homicídos em jovens, refletindo desvios de conduta e vulnerabilidades sociais, sendo que a violência dessa realidade perpassa instituições como a escola, exigindo formas de preveni-la na esfera da saúde. Assim, criamos um projeto de extensão sem fomento, para o desenvolvimento de relações mais saudáveis e não violentas que diminuam a vulnerabilidade dos sujeitos. Objetivamos realizar educação em saúde para jovens, estimulando interações e práticas sociais saudáveis. Trata- se de um relato de experiência sobre o projeto Levanta e Anda, realizado por estudantes de Medicina da UFMS/CPTL em 2018.2 para adolescentes da escola Padre João Tomes em Três Lagoas. Participaram 18 adolescentes com atraso na aprendizagem, histórico de heteroagressividade, abuso de drogas e comportamentos antissociais, selecionados pelos professores. Todos possuíam histórico de violência familiar, $15 \%$ sofreram espancamento e ameaças de morte do pai ou padrasto, $1 / 3$ sofreram abordagens violentas de policiais e $98 \%$ tinham comportamento impróprio durante as atividades do projeto, descumprido regras e praticando atitudes violentas e bem toleradas entre eles (chutes, beliscões, tapas, palavrões, empurrões e gritos). Realizamos dinâmicas de grupo e rodas de conversa/círculo de cultura sobre culturas de paz, autopercepção e valorização de aspectos pessoais positivos: gentileza, afeto, respeito, regras de boa convivência. As experiências do projeto mostram ser possível a interação entre estudantes de Medicina e adolescentes em escolas para reduzir a violência. O projeto promoveu uma reflexão sobre violência, tolerância, diálogo e valorização da vida. Por fim, concluímos que ações em saúde como esta podem auxiliar nas práticas de Medicina social e preventiva.

Descritores: Adolescente; Educação em Saúde; Medicina Social; Medicina Preventiva 


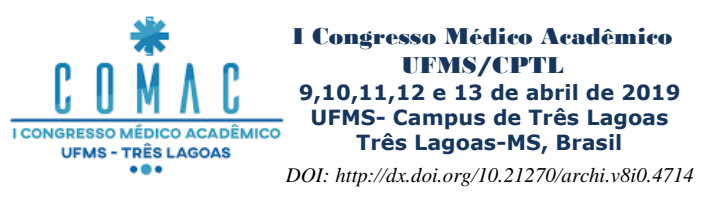

\section{MECANISMOS FISIOPATOLÓGICOS ENVOLVIDOS NA RELAÇÃO ENTRE DOENÇAS AUTOIMUNES E INFERTILIDADE FEMININA.}

Argondizzi, R.O.; Iaquinto, M.L.; Machado, A.R.S.R.; Machado, A.M.

renatoargondizzi@yahoo.com.br

Universidade Federal do Mato Grosso do Sul - Campus de Três Lagoas

Categoria: Pôster

Apesar da infertilidade feminina estar associada a diversas patologias, estudos recentes mostram uma relação entre doenças autoimunes e infertilidade. O Lúpus Eritematoso Sistêmico (LES) e a Diabetes Melitus 1 (DM1) podem afetar vários estágios da fertilidade. Apesar da literatura científica evidenciar a relação entre doenças autoimunes e infertilidade, pouco se sabe sobre os mecanismos fisiopatológicos envolvidos. Este trabalho propõe investigar os mecanismos fisiopatológicos das doenças autoimunes associados à infertilidade feminina. Foi realizada uma revisão narrativa da literatura em bases de dados, com seleção de artigos publicados entre 2005 a 2018. Observamos que a LES e a DM1 são as doenças autoimunes com maior relação com infertilidade. Pacientes com LES possuem ativação de resposta imune celular Th17, com produção de interleucinas (IL) como IL-17 e IL-21, bem como IL inflamatórias (IL-6 e IL-8). A IL-21 possui papel importante na manutenção da resposta Th17 e na ativação de células NK, TCD8+ e linfócitos B que polarizam o quadro inflamatório, o qual pode ser inapropriado para as fases iniciais da gestação e implantação, onde é necessária uma imunossupressão leve e transitória, bem como, uma posterior polarização para o padrão Th2. Além disso, estas mulheres podem apresentar irregularidade menstrual, ciclos anovulatórios e ooforite autoimune, justificados pelo desequilíbrio hormonal pela inflamação, uso de imunossupressores e produção de autoanticorpos. A DM1 também está associada a infertilidade, favorecendo o desenvolvimento da Síndrome do Ovário Policístico, relacionado a irregularidade menstrual ou a ciclos oligo ou anovulatórios, levando a uma redução de $20 \%$ da fertilidade. Concluímos que a relação entre infertilidade e autoimunidade ainda é muito pouco elucidada, sendo uma área com potencial para novas pesquisas.

Descritores: Infertilidade; Autoimunidade; Fisiopatologia. 


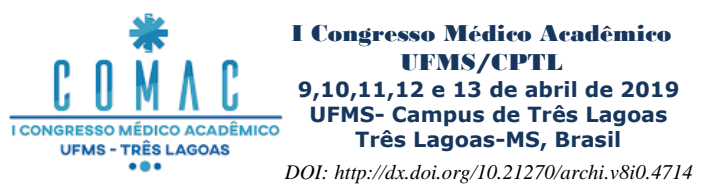

\section{MEDULOBLASTOMA: UMA ABORDAGEM INTEGRADA DE ASPECTOS CLÍNICOS E GENÉTICOS.}

Costa, F. P. R.; Silva, M. R.; Silva, A. V.

fabianoprochacosta@gmail.com

Universidade Federal de Mato Grosso do Sul - Campus de Três Lagoas

Categoria: Pôster

O meduloblastoma (MB) é o tumor cerebral mais comum da infância e importante causa de morbidade, dado os danos provocados pela radioterapia, quimioterápicos e cirurgias. O objetivo deste trabalho é compreender a relação entre as diferentes histologias e grupos moleculares e seu impacto na clínica, prognóstico e terapêutica. Utilizando a Biblioteca Virtual em Saúde, buscamos por artigos completos com os descritores "meduloblastoma", "terapia genética" e "tumor cerebral", em inglês, disponíveis na base de dados MEDLINE, de 2014 a 2018, obtendo-se 27 artigos dos quais selecionou-se 13. MB histologicamente classificam-se em: clássico (CMB), desmoplástico/nodular(DNMB), com extensa nodularidade (MBEN) e anaplásico/de células grandes (LCA); molecularmente em: SHH-MB, WNT-MB, G3-MB e G4-MB. SHH-MB desenvolvem-se nos hemisférios cerebelares e metástases são incomuns. DNMB e MBEN são histologias comuns. A formação da neoplasia se dá por superativação da SMO, cujos fármacos inibidores são terapia importante. WNT-MB tem o melhor prognóstico. Histologia principal de $\mathrm{CMB}$, sua barreira hematoencefálica é mais vulnerável, propiciando a ação de quimioterápicos. G3-MB é o que apresenta pior prognóstico e abrange LCA e CMB. Isocromossomo 17q (i17q) e amplificação de MYC são comuns. O uso de inibidor de bromodomain JQ1 (iBD) suprimindo MYC tem sido opção promissora. G4-MB representa 35\% dos casos, é comum a forma de CMB e LCA. Envolve i17q e expressão elevada de MYCN. Há poucas terapias para G4-MB, como os iBD. Assim, percebe-se que os subgrupos de MB são complexos do perfil genético e têm inúmeras diferenças entre si que influenciam seu potencial de metástase, prognóstico e alvos terapêuticos. WNT-MB é o de melhor prognóstico e os G3-MB e G4-MB os de piores, além de não possuírem linha de tratamento efetiva. Uma abordagem epigenética pode ser promissora.

Descritores: Meduloblastoma; Terapia Genética; Tumor Cerebral. 


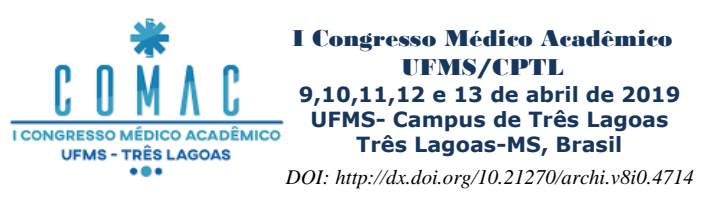

\author{
"MEMORIDADE": OFICINA DE MEMÓRIA PARA IDOSOS PARTICIPANTES DE UM \\ CENTRO DE CONVIVENCIA \\ Lima, A.P.S.; Augusto, A.C.S., Machado, V.P.; Vicente, A.C.; Oliveira, F. C.; Seixas, R.A.M. \\ anaapslima@gmail.com \\ Universidade Federal de Mato Grosso do Sul - Campus de Três Lagoas \\ Categoria: Pôster
}

Com a transição demográfica, novas perspectivas como o envelhecimento ativo surgem no intuito de melhorar a qualidade de vida da população idosa. As estratégias de treino cognitivo se destacam nesse cenário, bem como os centros de convivência que visam contribuir com o envelhecimento ativo, saudável e autônomo. O presente trabalho tem por objetivo descrever e avaliar as atividades desenvolvidas na oficina da memória para os idosos participantes do centro de convivência "Tia Nega" em Três Lagoas. A oficina "MemorIDADE" constituiu em uma proposta de estimulação cognitiva e psicossocial realizada no período de setembro a dezembro de 2018. Foram realizados 09 encontros semanais com duração aproximada de uma hora e meia, contando com a participação em média de 12 idosos por encontro, divididos em dois grupos (manhã/tarde). Antes e após a realização da oficina, realizou-se uma avaliação cognitiva de cada idoso. As atividades propostas abordavam diferentes dimensões cognitivas e aspectos da memória (de curto prazo, semântica, episódica e sensorial). No final de cada encontro os idosos avaliavam as atividades desenvolvidas. Dentre as atividades que foram melhor avaliadas pelo grupo encontraram-se o bingo sonoro, as estratégias para memória e os jogos lúdicos. Além dessas, foram realizadas diversas dinâmicas que visavam fortalecer tanto os aspectos cognitivos como as relações sociais entre os idosos (cooperação, escuta, solidariedade) e deles com os acadêmicos. Na avaliação final da oficina os idosos destacaram o aprendizado adquirido e as melhoras observadas na própria memória. Assim, essa experiência evidenciou-se como um recurso terapêutico potente para a promoção da saúde da população idosa, além de constituir-se como um espaço para o desenvolvimento das habilidades técnicas e humanistas para os acadêmicos de Medicina.

Descritores: Memória; Envelhecimento; Promoção da Saúde.

Apoio: Pró-Reitoria de Extensão, Cultura e Esporte/PROECE (Edital PROECE/FAPEC 8/2018) 


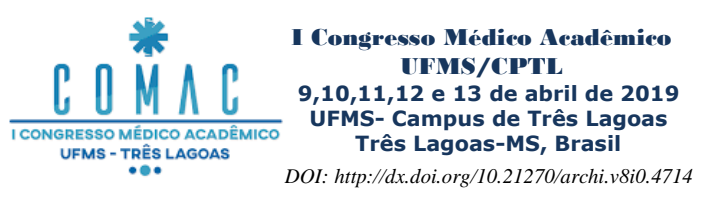

\section{MENSURAÇÃO DO FORAME JUGULAR EM CRÂNIOS SECOS DA REGIÃO CENTRO- OESTE DO MATO GROSO DO SUL}

Caldeira, J.V.C.; Godas, A.G.L.; Carvalho G.B.A.; Oda, J.Y.; Almeida, P.F.; Silva, A.V.

Universidade Federal de Mato Grosso do Sul - Campus de Três Lagoas

victorcamargoc@hotmail.com

Categoria: Apresentação Oral

O forame jugular (FJ) é considerado uma grande abertura irregular localizado na parte posterior da sutura occipitomastóidea entre o processo jugular do osso occipital e a fossa jugular, por ele passa uma série de estruturas importantes: a veia jugular interna, os nervos cranianos glossofaríngeo, vago e acessório, e eventualmente o seio petroso inferior, o que evidencia a importância clínica de se entender a anatomia desse forame bem como as relações e possíveis complicações de suas estruturas. O objetivo deste estudo foi realizar a análise morfométrica do FJ em crânios humanos, comparando os diâmetros anteroposterior (AP) e médio-lateral (ML) entre os gêneros. Foram selecionados de forma aleatória 104 crânios humanos do acervo do Laboratório de Anatomia da UFMS - CPTL, sendo divididos em 52 crânios masculinos e 52 crânios femininos. A mensuração foi realizada utilizando-se um paquímetro analógico 6" da marca Zaas Precision. Avaliou-se a morfometria do FJ no sentido anteroposterior e médio-lateral; Por análise visual foi pesquisada a presença de septação óssea completa $(8 \mathrm{FJ})$ e incompleta $(9 \mathrm{FJ})$. O diâmetro médio de todos os FJ, em ambos os gêneros, no eixo AP foi de $9,11 \mathrm{~mm}$ no lado direito e $8,5 \mathrm{~mm}$ no esquerdo e no eixo ML foi $13,53 \mathrm{~mm}$ do lado direito e $13,55 \mathrm{~mm}$ do esquerdo; evidenciando que o FJ é maior no diâmetro AP direito e no ML é semelhante; foi observado um aspecto oval do FJ ao longo do eixo médiolateral. O diâmetro AP do FJ direito foi maior no sexo feminino e no lado esquerdo em crânios masculinos; o diâmetro ML do FJ foi maior no sexo masculino bilateralmente. Desta forma, o FJ é uma estrutura importante para o estudo da base do crânio devido a sua diversificada anatomia, relações entre suas estruturas neurovasculares e seu variado aspecto e tamanho, logo compreender e estudar tal estrutura atrai a atenção de muitos neurocirurgiões e outros especialistas da área.

Descritores: Forame; Jugular; Crânio.

Apoio: Pesquisa de caráter voluntário, modalidade de iniciação científica PIBIC (Edital PROPP PIBICI/PIBIC-AF/PIBITI 095/2018 - Proposta: 40764.601.20376.10052018) 


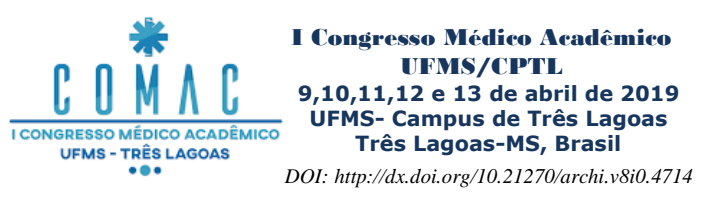

\section{MOTIVOS QUE LEVAM ESTUDANTES A CONSUMIREM ÁLCOOL E DROGAS EM UNIVERSIDADES BRASILEIRAS}

França D.G.; Albuquerque, A.S.; Ferrareto N.S.; Gomes, G.R.; Pimenta, A.S.; Moreira A.S.

Universidade Federal de Mato Grosso do Sul - Campus de Três Lagoas

danilloguedesfranca@gmail.com

Categoria: Pôster

O período universitário constitui uma fase da vida de muitos brasileiros, geralmente na adolescência e início da vida adulta. Época de eventos marcantes da vida, como o afastamento da família sofrido por muitos estudantes à procura da graduação em um curso superior, evidenciando-se também escolhas, decisões, conflitos e comportamentos que estabelecerão aspectos relevantes no decorrer da vida dessas pessoas. Acadêmicos mostram ter uma postura confusa em relação à sua identidade, tanto pelo cenário universitário quanto por seus impasses emocionais nessse fenômeno de amadurecimento, e podem ser acometidos de sofrimento mental e distúrbios psíquicos, indicados nos casos de depressão, ansiedade, estresse e distúrbios alimentares. O objetivo deste estudo é relacionar o uso de álcool e drogas entre os universitários brasileiros com os transtornos mentais, de modo a investigar as razões que levam a esse consumo e seus efeitos. Com isso, é possível evidenciar as principais influências que levam o acadêmico ao uso dessas substâncias. O conjunto de textos disponíveis no acervo bibliográfico pesquisado, Google Acadêmico, foi identificado por meio dos descritores: Drogas Ilícitas; Consumo de Álcool na Faculdade; Transtornos Mentais. A procura por estas publicações não respeitou limite temporal. Percebe-se que a universidade exige esforço, aprendizado e concentração, ampliando a vulnerabilidade a emoções que se exteriorizam em depressão, desânimo, ansiedade, fraqueza, insegurança ou mesmo realidades mais fragilizadas, como o consumo de substâncias psicoativas e enfermidades. Nesse contexto, por meio de influências sociais e ambientais, osdiscentes passam a ingerir bebidas alcoólicas ou a usar outros tipos de drogas, pois a própria rotina de estudos, exigências e preocupações com o futuro, aliados ao estresse, fornecem um ambiente propício.

Descritores: Drogas Ilícitas; Consumo de Álcool na Faculdade; Transtornos Mentais. 


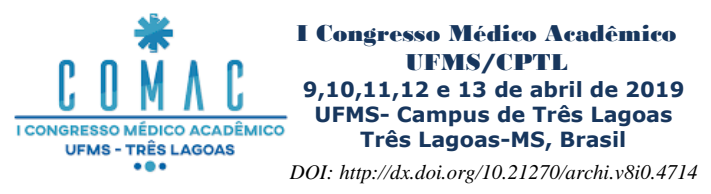

\section{O IMPACTO DA VIOLÊNCIA DOMÉSTICA NA SAÚDE PÚBLICA}

Yamaguti, N. G.; Pereira, I.; Moreira, A. S.

nathiele.yamaguti123@hotmail.com

Universidade Federal de Mato Grosso do Sul - Campus Três Lagoas

Categoria: Pôster

Atualmente a violência doméstica (VD) é a que mais acomete mulheres. É toda ação ou omissão que prejudique o bem-estar, a integridade física e psicológica. a liberdade e o pleno desenvolvimento da mulher. Se apresenta em 3 vertentes: física, psicológica e sexual. A física ocorre quando há dano por meio de força, arma ou instrumento que possa causar lesões. A psicológica inclui ação ou omissão que cause dano à autoestima, identidade ou desenvolvimento da pessoa. A sexual é toda ação na qual alguém, em situação de poder, obriga outrem à realização de atos sexuais, utilizando força física, influência psicológica, armas ou drogas. Trata-se de problema de saúde pública em que traumas físicos, agressões sobrepostas e acumuladas podem ocasionar distúrbios afetivo-emocionais, problemas de incapacidade física, muitas vezes de modo irreversíveis. Assim, tem por objetivo este trabalho, identificar os principais impactos da VD contra mulheres na saúde pública, por meio de método de revisão de literatura. Assim, foi possível constatar que a violência física pode causar lesões internas, externas ou ambas, proporcionando hematomas e traumas físicos. Já a psicológica não é visível, embora cause dano à autoestima, à identidade ou ao desenvolvimento da mulher, podendo levar a fobias, crises de ansiedade, pânico e depressão. No caso da sexual o ato pode levar a gestações indesejadas, abortos induzidos, problemas ginecológicos e DSTs. Os custos sociais e econômicos dessa violência são enormes e repercutem em toda a sociedade. Concluímos que mulheres estão procurando mais pelos serviços de saúde, e, na maioria das vezes, a saúde pública não possui o preparo para tal acolhimento. Além disso, há também impacto no setor financeiro, visto que há maior demanda de atendimentos dessa natureza e o aumento do custo com os pacientes, o que esbarra na permanente falta de recursos do SUS.

Descritores: Saúde Pública; Violência Doméstica; Impactos na Saúde. 


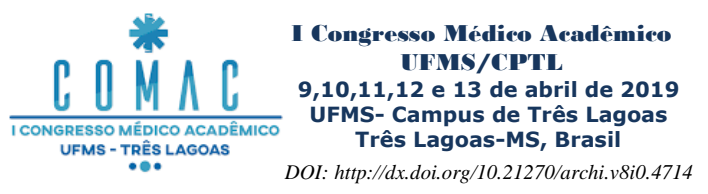

\author{
COM ESCLEROSE MÚLTIPLA \\ Ferrareto N.S.; Pimenta A.S.; Silva A.V. \\ nataliaferrareto21@gmail.com \\ Universidade Federal de Mato Grosso do Sul - Campus de Três Lagoas \\ Categoria: Pôster
}

O IMPACTO DOS DÉFICITS COGNITIVOS NA QUALIDADE DE VIDA DOS PACIENTES

A esclerose múltipla (EM) é uma doença neurodegenerativa crônica e progressiva, caracterizada pelo reconhecimento errôneo do sistema imunológico em relação à bainha de mielinano sistema nervoso central (SNC). Na fase inicial, há um predomínio do processo inflamatório, enquanto o fenômeno degenerativo de caráter desmielinizante prevalece ao decorrer da evolução da doença. Existem quatro subtipos clínicos: surto-remissão, progressiva primária, progressiva secundária e progressiva recorrente. Essa patologia apresenta sinais e sintomas de comprometimento disseminado no SNC, dentre os quais se destaca o aspecto cognitivo.Considerando que a EM é uma patologia progressiva a qual pode afetar o SNC em sua totalidade, objetivou-se realizar uma revisão sistemática sobre o impacto dos déficits cognitivos na qualidade de vida dos portadores da EM.Foram encontrados 44 artigos publicados no período de 2013 a 2018, nas bases de dados PubMed, Google Acadêmico e Scientific Electronic Library online (Scielo) com os descritores "Esclerose múltipla", "Cognição" e "Neurologia".Estudos contemporâneos indicam uma prevalência variável de $43 \%$ a $72 \%$ de acometimento na cognição durante o curso da EM. Diversos aspectos cognitivos estão comprometidos, incluindo atenção, aprendizado, concentração, habilidades visuoespaciais, memória, velocidade de processamento das informações, planejamento e execução de funções, além de causar prejuízo motor, fadiga e depressão. A descoberta do diagnóstico de doença neurodegenerativa progressiva, de caráter incapacitante e sem cura, provoca repercussão drástica na vida dos pacientes, mesmo nas etapas iniciais. Isso porque os déficits cognitivos não refletem apenas nos âmbitos emocional, social e nas atividades laborais, mas também na sexualidade e nas tarefas cotidianas, o que implica em redução da qualidade de vida.

Descritores: Esclerose Múltipla; Cognição; Neurologia. 


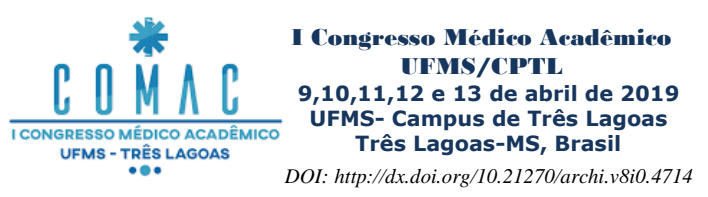

\section{O PAPEL MASCULINO NO CONTEXTO DA GRAVIDEZ EM ESCOLARES: UM RELATO DE EXPERIÊNCIA.}

Parente, G.S.; Cesário, E.S.; Gama, I.C.S.; Bogado, S. S.G. Pessalacia, J.D.R.

giparente2@yahoo.com

Universidade Federal de Mato Grosso do Sul - Campus de Três Lagoas

Categoria: Pôster

Introdução: Na adolescência, o conhecimento ou uso inadequado de métodos contraceptivos aliados a fatores de vulnerabilidade emocional e social podem culminar em uma gravidez não planejada. Justificativa: Contribuir para a construção do conhecimento sobre métodos contraceptivos, responsabilidade paterna na gravidez e empoderamento de adolescentes escolares. Objetivo: Relatar a experiência de acadêmicos de Medicina em ações de Educação em Saúde na Escola sobre o papel masculino no contexto da gravidez precoce. Metodologia: Trata-se de um relato de experiência, desenvolvido durante as atividades de Vigilância em Saúde, pertencente à grade curricular de um curso de Medicina de uma universidade pública federal no estado do Mato Grosso do Sul. A experiência ocorreu a partir das vivências em uma escola pública de Ensino Fundamental. Resultados: Os acadêmicos organizaram uma palestra, onde ocorreram aconselhamentos para a não concretização de uma gravidez precoce, instruções de como agir caso essa ocorra, assim como a importância da figura paterna. As dinâmicas e testes aplicados com os jovens possibilitou a constatação de concepções pré-formadas sobre métodos contraceptivos, visão social do papel feminino e as responsabilidades paternais. Considerações finais: As práticas de educação em saúde atuam como um mecanismo para garantir o bem estar e autonomia para população, além de contribuir para a solidificação de conhecimentos dos estudantes e fornecer condições para a construção de uma boa relação entre futuros profissionais de saúde e a comunidade.

Descritores: Educação de Graduação em Medicina; Gravidez na Adolescência; Paternidade. 


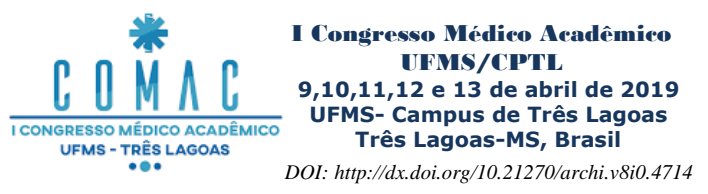

\section{O USO DO LASER DE BAIXA INTENSIDADE EM LESÕES MAMILARES DECORRENTES DO ALEITAMENTO MATERNO: UMA REVISÃO INTEGRATIVA}

Weis, M.; Pereira, L.V.R.C.; Jurado, S.R.

matheus.weis@outlook.com

Universidade Federal de Mato Grosso do Sul - Campus de Três Lagoas

Categoria: Pôster

A amamentação é a forma ideal de nutrição para os primeiros seis meses da criança. Porém, a oferta de outros alimentos e a interrupção do aleitamento antes desse período é bastante comum, principalmente, relacionado aos episódios de dores e traumas mamários. A terapia com laser de baixa intensidade pode contribuir nesses casos pela ação analgésica, antiflamatória e cicatrizante. O objetivo desse trabalho foi analisar na literatura os benefícios da laserterapia no tratamento de lesões mamilares decorrentes do aleitamento materno. Tratou-se de uma revisão integrativa, realizada nas bases de dados Literatura Latino-Americana e do Caribe em Ciências da Saúde (LILACS), Sistema Online de Busca e Análise de Literatura Médica (MedLine), da Scientific Electronic Library Online (SciELO), através dos Descritores em Ciências da Saúde (DeCS) "aleitamento materno" [and] "terapia a laser" [and] "mama", sendo selecionados oito, no período de 2000 a 2018 e que atenderam aos critérios de inclusão. Os estudos divergiram quanto à avaliação das lesões e da sua evolução. Um artigo realizou a análise do tratamento por meio de fotografias, outro através das medidas das lesões e os demais avaliaram por questionários qualitativos. Apenas um deles não encontrou melhora significativa após uso do laser de baixa intensidade no tratamento das fissuras mamárias. A laserterapia possui potencial para auxiliar na regeneração de tecidos, para aumentar a qualidade de vida da lactante e a adesão ao aleitamento materno. $\mathrm{O}$ uso mais comum e conhecido do laser é na cicatrização de fissuras mamilares, contudo, também pode ser utilizado nos casos de dor mamilar, ingurgitamento e mastite, É necessário que novos estudos sejam realizados na literatura nacional, que ainda apresenta poucos trabalhos sobre o tema.

Descritores: Aleitamento Materno; Terapia a Laser; Mama. 


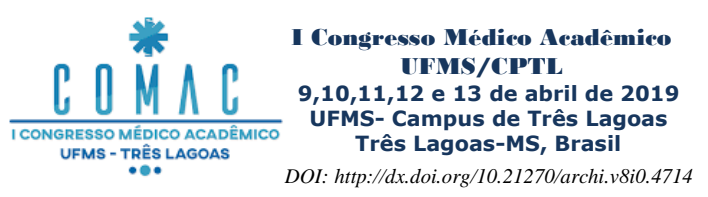

\section{OFICINA DE MEMÓRIA COMO ESTRATÉGIA DE TREINO COGNITIVO PARA IDOSOS EM CENTRO DE CONVIVÊNCIA}

Machado, V.P.; Oliveira, F.C.; Vicente, A.C.F.; Augusto, A.C.S.; Lima, A.P.S.; Luchesi, B.M.

vitormachado.p@gmail.com

Universidade Federal de Mato Grosso do Sul - Campus de três Lagoas

Categoria: Pôster

O Brasil tem passado por um processo de transição demográfica, com o aumento da expectativa de vida e do acesso aos serviços de saúde, culminando num aumento da população acima dos 60 anos de idade. Essa população possui especificidades, e uma delas é o possível declínio nas funções cognitivas, dentre elas a memória, o que pode interferir na qualidade de vida dos idosos. Nesse contexto, práticas de treino cognitivo têm sido usadas para conservar e melhorar as funções cerebrais. O objetivo da pesquisa foi avaliar os impactos promovidos por uma oficina na cognição de idosos. A oficina foi realizada num Centro de Convivência na cidade de Três Lagoas/MS, em nove encontros semanais, com duração de 90 minutos cada. Os temas trabalhados focaram na memória episódica e operacional, além das difículdades com memória encontradas no dia-a-dia, utilizando estratégias que envolveram a participação e interação dos idosos. Participaram 10 idosos que foram avaliados antes e após a oficina por meio do Exame Cognitivo de Addenbrooke - versão revisada (ACE-R), o qual possui cinco domínios (atenção/orientação, memória, fluência verbal, linguagem e visuoespacial) e pontuação possível de 0-100 (quanto maior, melhor o desempenho cognitivo). $\mathrm{O}$ teste $\mathrm{T}$ foi utilizado para comparar a pontuação no instrumento antes e após a oficina. Dos 10 idosos, dois eram homens e oito mulheres, com média de 70,6 anos de idade e 5,0 de escolaridade. Observou-se melhora na pontuação geral (antes=64,8/ após=69,0/ $\mathrm{p}=0,160$ ) do ACE$\mathrm{R}$, sendo esta melhora significativa nos domínios memória (antes $=12,8 /$ após $=14,8 / \mathrm{p}=0,044$ ) e linguagem (antes $=3,1 /$ após $=6,7 / \mathrm{p}=0,025$ ). A melhora encontrada indica que a oficina teve impacto na cognição dos idosos, principalmente nos domínios que foram trabalhados nos encontros da oficina. Os dados evidenciam a importância de estratégias de treino cognitivo para esta população.

Descritores: Idoso; Terapia Cognitivo-Comportamental, Centros Comunitários para Idosos.

Apoio: Pró-Reitoria de Extensão, Cultura e Esporte/PROECE (Edital PROECE/FAPEC 8/2018). 


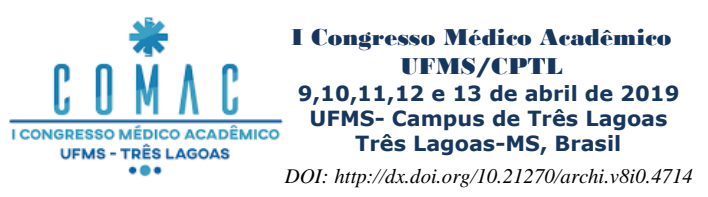

\section{PERFIL ANTROPOMÉTRICO DE ADULTOS E IDOSOS CADASTRADOS NA ESTRATÉGIA SAÚDE DA FAMÍLIA}

Ribeiro, A.M.F.; Augusto, A.C.S; Silva, L. A.; Carrijo, M.F.; Luchesi, B.M.; Martins, T.C.R. anamaria.farias1501@gmail.com

Universidade Federal de Mato Grosso do Sul - Campus de Três Lagoas

Categoria: Pôster

A antropometria viabiliza informações das medidas que podem retratar o estado da saúde populacional, sendo um recurso não-invasivo, facilmente executável e de baixo custo. O objetivo de estudo foi estimar a prevalência de obesidade em adultos e idosos cadastrados na Estratégia Saúde da Família (ESF) do município de Três Lagoas/MS. Trata-se de um estudo transversal e quantitativo, realizado no período de 2018/2019, em indivíduos com idade $\geq 45$ anos, de ambos os sexos, cadastrados nas ESF no município de Três Lagoas-MS. O instrumento de coleta de dados utilizado foi um questionário estruturado. A obesidade foi avaliada usando como base o Índice de Massa Corporal (IMC), sendo considerado obeso os adultos (45-59 anos) com IMC $\geq 30 \mathrm{~kg} / \mathrm{m} 2$, e os idosos ( $\geq 60$ anos) com IMC $\geq 27 \mathrm{~kg} / \mathrm{m} 2$, conforme preconizado pelo Ministério da Saúde. O tratamento dos dados foi feito por meio da estatística descritiva com distribuição de frequências. Dos 99 participantes, a maioria era do sexo feminino $(62,6 \%)$, com idade $\geq 60$ anos (52,5\%), possuía de 5-8 anos de escolaridade (32,3\%) e eram obesos $(51,5 \%)$. Houve uma maior proporção de obesos em indivíduos do sexo feminino (55\%), com idade $\geq 60$ (62\%), com menor escolaridade $(56,9 \%)$ e sem companheiro $(57,8 \%)$. Em relação aos hipertensos, $69,6 \%$ eram obesos ao passo que, dos normotensos, apenas 29,3\%. Entre os diabéticos, 65,5\% apresentaram obesidade assim como $47,1 \%$ dos não diabéticos. Os resultados evidenciam a relação existente entre a obesidade, a hipertensão e a diabetes, além de mostrar que os idosos e os indivíduos com menor escolaridade apresentam maiores taxas de obesidade. Por fim, o estudo mostra-se imperioso ao retratar a necessidade de medidas públicas como maior investimento em equipes multiprofissionais nas Unidades de Saúde, realizando ações acerca do tema obesidade a fim de amenizar esse problema de saúde pública.

Descritores: Antropometria; Idoso; Obesidade. 


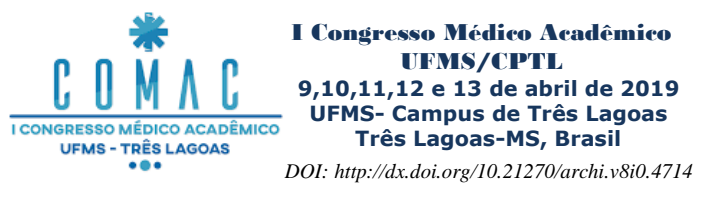

\author{
PERSPECTIVAS PSICOSSOCIAIS DA "SÍNDROME DO NINHO VAZIO": UMA REVISÃO \\ INTEGRATIVA \\ Candido, M.T., Godas, A.G.L, Fonseca, A.G., Carvalho, G.B.A., Caldeira, J.V.C., Moreira, A. \\ mateustcandido@gmail.com \\ Universidade Federal de Mato Grosso do Sul - campus de Três Lagoas \\ Categoria: Pôster
}

A síndrome do ninho vazio (SNV) é acompanhada da solidão e depressão dos pais em resposta à partida de seus filhos de casa. O objetivo deste ensaio foi realizar uma revisão Integrativa de Literatura (RIL) buscando informações existentes até o momento sobre a síndrome do ninho vazio, bem como fazer crítica reflexão sobre elas, relacionando-as ao atualizado conhecimento de fisiopatologia e psicologia para melhor compreender as manifestações desse estágio da vida familiar e, assim, constituir-se numa clara exposição a respeito do tema. Realizou-se uma pesquisa nas bases de dados Literatura Latino-Americana e do Caribe em Ciências da Saúde (LILACS) e Sistema Online de Busca e Análise de Literatura Médica (MedLine), utilizando apenas um descritor: "empty nest syndrome". Apenas artigos completos e publicados nos idiomas português, inglês e espanhol, dos anos de 2007 a 2017 compuseram este estudo. Foram excluídas teses, dissertações, monografias e artigos em duplicata. Encontrou-se um total de 28 artigos, dos quais foram selecionados nove artigos para a análise, após a leitura de seus resumos, preocupando-se com o assunto principal de cada texto. Foram elencadas três categorias: $\mathrm{O}$ estilo de vida dos familiares como facilitador da SNV, Sinais e sintomas que podem levar ao desenvolvimento da SNV e a influência do local que os familiares vivem no desenvolvimento da SNV. Fica clara relação causal entre sinais e sintomas psiquiátricos e a SNV, de maneira que o enfrentamento positivo ou negativo da fase pós-parental pode acarretar em agravos psicopatológicos, bem como ser positivo para a vida familiar. $\mathrm{O}$ estilo de vida e local em que a família assiste influem intensamente na maneira pela qual a família atravessa tal período. Fatores como gênero, condição socioeconômica e hierarquia de trabalho também são capazes de modificar a resposta da família à SNV.

Descritores: Solidão; Relações Familiares; Relações Pais-Filho. 


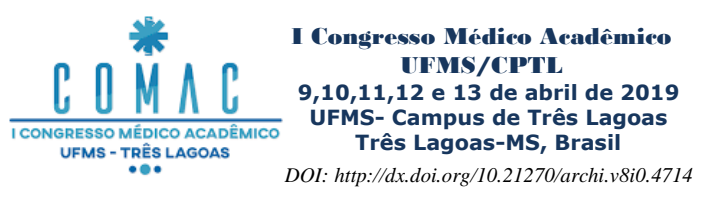

\section{POSSÍVEIS EFEITOS DA EXPOSIÇÃO PERINATAL A PARABENOS E FTALATOS, ISOLADOS OU EM ASSOCIAÇÃO, SOBRE A SAÚDE REPRODUTIVA DA PROLE FEMININA DE RATOS}

Iaquinto, M.L.; Cleto, P.H.; Costa, W.F.; Nunes, T.D.A.M.; Fernandes, G.S.A.; Guerra, M.T.

mirelli10@ hotmail.com

Universidade Federal do Mato Grosso do Sul - Campus de Três Lagoas

Categoria: Pôster

Parabenos e ftalatos são compostos amplamente utilizados na indústria farmacêutica e cosmética. Estes compostos são constantemente encontrados como contaminantes em fluidos e tecidos biológicos humanos. Estudos demonstram que eles são considerados desreguladores endócrinos, alterando o funcionamento normal do sistema reprodutor. Considerando que a exposição a essas substâncias pode ocorrer de forma simultânea, esse trabalho visou avaliar os efeitos da exposição concomitante destes compostos sobre o desenvolvimento sexual de ratas. Ratas Wistar prenhes foram alocadas em seis grupos experimentais: grupo controle gavage $(n=6)$, que recebeu o veículo (óleo de milho) via oral; grupo controle subcutâneo $(n=6)$ que recebeu o veículo via injeções subcutâneas (s.c.); grupo controle gavage + subcutâneo $(n=5)$ exposto ao veículo vias oral e s.c.; grupo butilparabeno $(B P, n=7)$ tratado com 100 $\mathrm{mg} / \mathrm{kg}$ via s.c.; grupo $\mathrm{Di}(2$-etilhexil)ftalato (DEHP, $\mathrm{n}=5$ ) tratado com $500 \mathrm{mg} / \mathrm{kg}$ por gavage; e grupo $\mathrm{BP}+$ DEHP ( $\mathrm{n}=8$ ), exposto simultaneamente a $100 \mathrm{mg} / \mathrm{kg}$ BP via s.c. e $500 \mathrm{mg} / \mathrm{kg}$ DEHP, via oral. As doses estabelecidas representam a LOAEL para parâmetros reprodutivos em roedores. As ratas foram expostas às substâncias do dia gestacional 12 até o final da lactação (dia pós-natal 21- DPN 21). Na prole feminina foram analisados: peso nos DPN 1, 13, 21 e no dia da abertura vaginal, distância anogenital relativa no DPN1, número de mamilos no DPN13, instalação da puberdade (a partir do DPN 30) e regularidade do ciclo estral (a partir do DPN 60). Os grupos expostos ao DEHP e BP, de forma isolada ou simultânea, apresentaram todos os parâmetros avaliados similares aos grupos controle. Podemos concluir que, nestas condições experimentais, a exposição materna ao ftalato e parabeno (isolados ou em associação) não prejudicou e desenvolvimento sexual da prole feminina.

Descritores: Dietilexilftalato; Parabenos; Disruptores Endócrinos. 


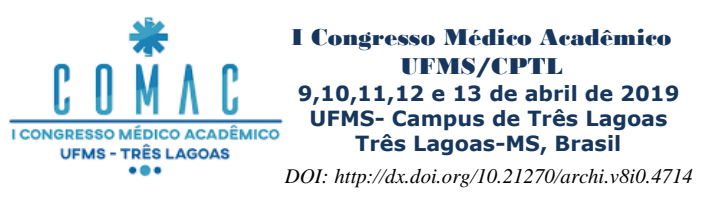

POTENCIAIS BIOMARCADORES DE DIAGNÓSTICO PARA A DOENÇA DE ALZHEIMER

Brito, C. V.; Parreira-Neto, C. M.; França, D. G.; Oliveira, F. C.; Mateus, G. B. L.; Belini-Junior, E. camilavenciobrito@gmail.com

Universidade Federal de Mato Grosso do Sul - Campus de Três Lagoas

Categoria: Pôster

Doença de Alzheimer (DA) é uma afecção neurodegenerativa progressiva e irreversível, de acometimento tardio, que leva à perda de memória e cognição. Devido à alta prevalência mundial da DA e as complicações clínicas que afetam as pessoas, o diagnóstico precoce pode auxiliar na terapia evitando sequelas neurológicas. O objetivo do estudo foi identificar biomarcadores para auxiliar no diagnóstico da DA e nas intervenções preventivas da doença. A base de dados utilizada foi a Biblioteca Virtual em Saúde com os descritores "doença de Alzheimer", "genética" e "biomarcadores". Foram selecionados 15 artigos publicados a partir de 2017 com o título e/ou resumo compatíveis com o tema estudado. Dentre os biomarcadores, se destacam os proteicos: alfa-2 macroglobulina (marcador pré-clínico por remeter lesão neuronal e estar associada a um risco de três vezes maior de progressão de sintomas da DA) e clusterina (aumentada na DA e associada ao menor volume do córtex entorrinal, região atrofiada no início da DA). Dentre os genéticos, genes APP, PSEN1 e PSEN2 (mutações estão associadas com precocidade da DA e juntas explicam 5 a 10\%); gene $A P O E$ (o alelo $\varepsilon 4$ tem risco aumentado para DA de três vezes e 15 vezes em heterozigotos e homozigotos, respectivamente); genes BACEl e RIPKl (a superexpressão têm demonstrado forte associação com a DA); microRNAs (miRNA-107, miRNA-29c-3p e miRNA-19b-3p estão diminuídos na DA e contribuem para etiologia da DA); gene $M E F C$ (baixa expressão reflete diminuição da plasticidade neuronal e da proteção contra apoptose, menor diferenciação das estruturas sinápticas e influencia na aprendizagem e memória. Os resultados apresentados demonstram a importância dos biomarcadores para o diagnóstico precoce e possíveis intervenções da DA, sendo ainda necessário mais estudos da aplicação e reprodução na prática clínica destes e de outros biomarcadores.

Descritores: Doença de Alzheimer; Biomarcadores; Diagnóstico. 


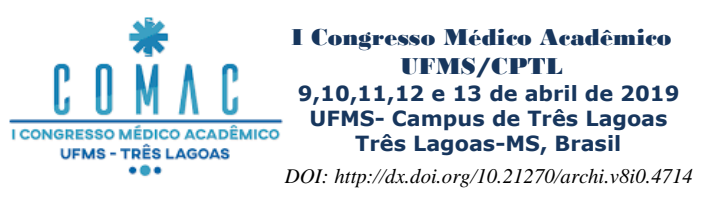

\section{PRÁTICAS RECREATIVAS EM INSTITUIÇÕES DE LONGA PERMANÊNCIA PARA IDOSOS: REVISÃO INTEGRATIVA DE LITERATURA}

Pereira, F.D.A.; França, V.O.; Pereira, A.G.; Matusin, B.S.; Pessalacia, J.D.R.

felipe_damsceno_alves@hotmail.com

Universidade Federal do Mato Grosso do Sul - Campus Três Lagoas.

Categoria: Pôster

Introdução. O Brasil passa por uma transição demográfica, caracterizando um envelhecimento populacional. Logo, instituições que supram as especificidades dessa mudança são fundamentais. As Instituição de Longa Permanência do idoso (ILPIs) funcionam segundo o Estatuto do Idoso, desenvolvendo atividades educacionais, esportivas, culturais e de lazer, assegurando um envelhecimento ativo aos residentes. Objetivo. Identificar na literatura nacional os estudos que abordam a temática das práticas recreativas em ILPIs. Metodologia. Trata-se de um estudo do tipo Revisão Integrativa de Literatura (RIL), que visa responder à questão norteadora: 'Quais são os estudos que abordam a temática das práticas recreativas em ILPIs?' A busca foi realizada por meio dos descritores controlados: 'Instituição de Longa Permanência para Idosos' e 'Atividade de Lazer', combinados através do operador boleano AND. Foram selecionados artigos completos disponíveis em português, nas bases de dados Literatura Latino-Americana e do Caribe em Ciência da Saúde (LILACS) e Sistema Online de Busca e Análise de Literatura Médica (MEDLINE), considerando-se o espaço temporal de 2005 a 2017. Resultados: Foram selecionados 20 artigos na busca inicial, os quais 13 restaram após os critérios de inclusão. A partir da análise dos artigos, emergiram as categorias: 'Perfil dos profissionais que estimulam o lazer nas ILPIs', 'Fatores favoráveis a implementação das atividades nas ILPIs' e 'Benefícios da implementação das atividades de lazer e recreação'. Conclusão. O estudo evidenciou a importância das atividades de lazer realizadas em ILPIs e como elas influenciam positivamente nos indivíduos residentes, propiciando maior interação social e meios para expressão de sentimentos.

Descritores: Assistência Integral à Saúde; Saúde do Idoso Institucionalizado; Instituição de Longa Permanência para Idosos. 


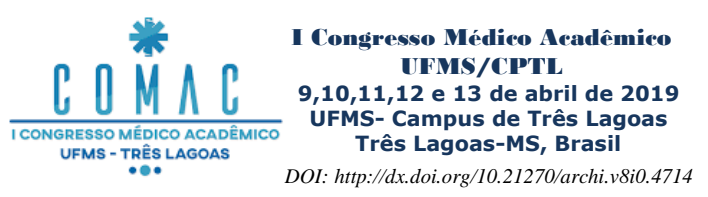

\section{PREVALÊNCIA DE FRAGILIDADE E PRÉ-FRAGILIDADE EM IDOSOS CADASTRADOS NA ESTRATÉGIA SAÚDE DA FAMÍLIA}

Alves, A.M.; Andrade, N.O.; Alencar, T.S.; Oliveira, F.C.; Martins, T.C.R.; Luchesi, B.M.

alinema12@gmail.com

Universidade Federal de Mato Grosso do Sul - Campus de Três Lagoas

Categoria: Apresentação Oral

O envelhecimento é um processo em que ocorrem modificações biopsicossociais, as quais podem ampliar o risco a fatores relacionados à morbimortalidade. À vista disso, pode surgir a fragilidade, a qual é entendida como uma síndrome em que determinadas manifestações clínicas presentes podem indicar maior propensão a desenvolver futuras complicações. Desse modo, evidencia-se a importância do rastreio da fragilidade, que pode coadjuvar para prorrogação ou diminuição de agravos. O objetivo foi avaliar a prevalência de fragilidade e pré-fragilidade em idosos cadastrados na Estratégia Saúde da Família (ESF). Trata-se de um estudo transversal e quantitativo, realizado no período de 2018/2019, com 52 idosos (idade $\geq 60$ anos), de ambos os sexos, cadastrados nas ESF no município de Três Lagoas-MS. Foram coletados dados de caracterização sociodemográfica e aplicado instrumento de fragilidade autorreferida proposto por Nunes e colaboradores. Foi calculada a frequência simples das variáveis. Dentre os 52 idosos, a maioria era do sexo feminino (55,8\%), na faixa etária de 60-69 anos (55,8\%), possuía de 1 a 4 anos de escolaridade (40,4\%), renda mensal de 1 a 3 salários mínimos $(48,1 \%)$ e 57,7\% eram casados/união estável. A prevalência de fragilidade entre os idosos foi de 50,0\%, 36,5\% classificaram-se como pré-frágeis e $13,5 \%$ não apresentaram fragilidade. A fragilidade foi frequente na população idosa avaliada, bem como a pré-fragilidade, o que é alarmante visto que está relacionada à desfechos como hospitalização, quedas, incapacidade e morte. Os resultados encontrados devem instigar os gestores públicos para a imprescindibilidade do conhecimento sobre a fragilidade em idosos e desviar práticas preventivas para todos os indivíduos não frágeis e em processo de fragilização. Deste modo, é importante a incorporação dessa avaliação na rotina das equipes de saúde.

Descritores: Idoso Fragilizado; Vulnerabilidade em Saúde; Fatores Epidemiológicos. 


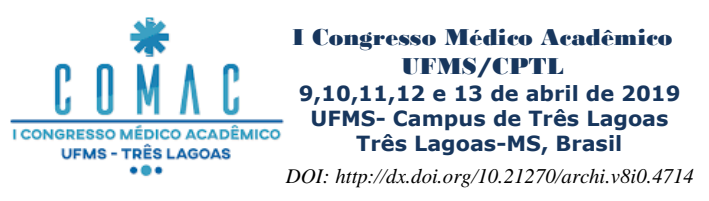

\section{PREVENÇÃO ÀS DROGAS NO CONTEXTO ESCOLAR EM ALUNOS DO ENSINO FUNDAMENTAL: UM RELATO DE EXPERIÊNCIA}

França, V.O.; Pereira, F.D.A.; Salles, L.O.; Duarte, E.B.; Pessalacia, J.D.R. viofranca@gmail.com

Universidade Federal do Mato Grosso do Sul - Campus Três Lagoas.

Categoria: Pôster

Introdução. A utilização de substâncias psicoativas é um problema de saúde mundial entre os jovens, sendo importantes causas de morbidade e mortalidade nesta população. $O$ efeito além de individual, fomenta danos públicos por utilização de substâncias ilícitas, essas têm origem clandestinas do tráfico, ou seja, os usuários alimentam atividades ilegais para terem acesso ao efeito físiológico desses ativos. Objetivo. Relatar a experiência de acadêmicos de Medicina em uma ação de Educação em Saúde na Escola sobre prevenção de uso de drogas. Metodologia. Relato de experiência, a partir das vivências de acadêmicos de Medicina de uma universidade pública federal do estado de Mato Grosso do Sul, em uma ação de Educação em Saúde sobre Drogas com alunos pertencentes ao ensino fundamental de uma escola pública municipal. Resultados. A temática foi abordada com a utilização de métodos dinâmicos por parte dos acadêmicos, utilizando uma linguagem mais próxima do jovem e brincadeiras elucidativas, foram realizadas dinâmicas envolvendo balões para abordarmos as influências, outra dinâmica faz referência aos grupos sociais que os adolescentes buscam se inserir, como resultado conseguimos relacioná-las de maneira objetiva. Podemos observar que a aproximação que o trabalho proporcionou para os estudantes de medicina com a sociedade, mostra uma medicina mais integrativa com os outros órgãos públicos além dos sistemas de saúde. Conclusão. Esse trabalho mostrou a efetividade e a importância de ações em outros eixos sociais por parte da medicina e do estudante em sua formação. Notamos que a educação em seu aspecto geral já é um grande passo para o desenvolvimento crítico do aluno do Ensino Fundamental. Entretanto, a abordagem correta e específica sobre o assunto pode trazer grandes avanços nas suas formas de pensar perante o mundo e as influências que os rodeiam.

Descritores: Drogas Ilícitas; Ensino Fundamental; Saúde do Adolescente. 


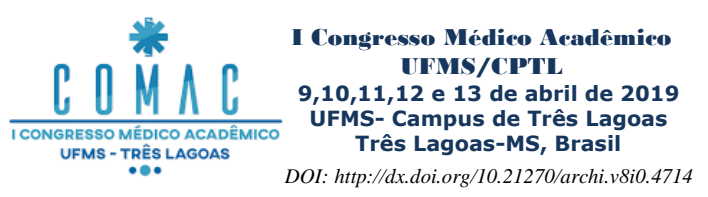

\section{PRIMEIROS SOCORROS NO AMBIENTE ESCOLAR: UMA REVISÃO DE LITERATURA}

Cesário, E.S.; Cunha, P.H.B.; Galvão, R.G.; David, T.C.; Couto, S.B.; Martins, T.C.R.

dudobss@gmail.com

Universidade Federal de Mato Grosso do Sul- Campus de Três Lagoas

Categoria: Pôster

A grande diversidade de atividades realizadas e o longo tempo que os estudantes vivenciam no ambiente escolar tornam a escola um cenário favorável a acidentes. Assim, os profissionais que acompanham esses jovens têm um importante papel na abordagem dos primeiros socorros de possíveis intercorrências, sendo que, o despreparo desses profissionais acerca do assunto pode culminar em maiores agravos. O objetivo desta pesquisa foi analisar e discutir a produção científica brasileira sobre ações de prevenção de acidente no ambiente escolar. Trata-se de um estudo bibliográfico, descritivo, tipo revisão integrativa, com busca de artigos publicados nas bases de dados LILACS e BDENF, com os descritores: "Educação em Saúde", "Saúde Escolar" e "Primeiros Socorros". Foram selecionados artigos na íntegra, em português e que apresentavam relevância ao objeto de estudo. Após aplicados os critérios de inclusão e exclusão, foram elencados 8 artigos, publicados entre os anos de 2008 e 2018. Os estudos foram agrupados segundo seu objetivo principal em três categorias, sendo que, na primeira (1), identificaram-se estudos voltados a ação de educação em saúde sobre primeiros socorros para professores, enquanto na segunda categoria (2), focou-se em práticas educativas sobre primeiros socorros para estudantes. Já a terceira categoria (3) aborda o desenvolvimento de escalas analógicas que objetivam mensurar o grau de conhecimento dos profissionais de saúde a respeito do tema. Constata-se a relevância da capacitação de professores para que haja uma atuação adequada frente à intercorrências de saúde dos escolares. Assim, destaca-se a importância de políticas de promoção de saúde que habilitem a atuação desses profissionais frente a essas intercorrências, além do desenvolvimento de escalas que possam mensurar o grau de conhecimento destes profissionais sobre o assunto.

Descritores: Educação em Saúde; Saúde Escolar; Primeiros Socorros. 


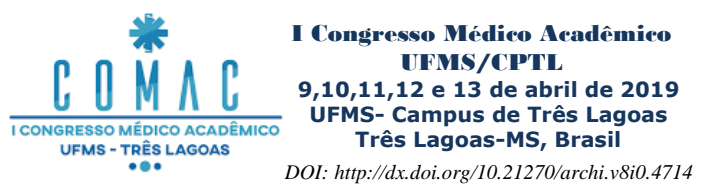

\section{PROGRAMADAS PARA MATAR: UMA REVISÃO SOBRE O PAPEL DAS CÉLULAS NK NO COMBATE TUMORAL E DE METÁSTASE}

Souza, R.F.; Oliveira, M.D.; Oda J.Y.; Machado, A.R.S.R..; Machado, A.M.

rachidsouza2@hotmail.com

Universidade Federal de Mato Grosso do Sul - Campus de Campo Grande

Categoria: Pôster

As células Natural Killer (NK) são potentes assassinas de células malignas, com importância direta no controle tumoral. Pesquisas recentes têm evidenciado novos papeis destas células no combate a tumores, entretanto, os mecanismos envolvidos no controle tumoral pelas NKs ainda são discutidos. Assim, este trabalho objetiva investigar as novas funções das células NK e os mecanismos envolvidos em sua ação. Foi realizada uma revisão narrativa da literatura em bases de dados (Pubmed), com seleção de artigos publicados no período entre 2010 a 2019. Células NK, após ativação mediada por IL-2, IL-12, IL-15 e IL18, podem atenuar o crescimento tumoral através da citotoxicidade mediada por grânulos citolíticos, secreção de IFN-gama e TNF-alfa ou ação antitumoral direta. O controle de metástase pelas NKs é especialmente intrigante, sendo observado que a presença destas em tumores correlacionam com melhor prognóstico e menor desenvolvimento de metástase. Estudos recentes demonstram que as NKs podem, além de combater os tumores, prevenir a disseminação metastática pela ativação de receptores como o NKp46, que induz via Ncr-1 (receptor de citotoxicidade natural 1) a produção de IFN-gama, levando ao aumento na expressão da proteína de matriz extracelular, fibronectina 1 (FN1) nos tumores, que altera a arquitetura tumoral e resulta na diminuição metastática. Estes estudos foram recentemente comprovados in vivo, em modelos animais, onde observou-se uma redução significativa de metástases quando ativadas células NKs peritumorais com IFN-gama via Ncr-1. Concluímos assim que o papel das NK no combate tumoral é bem vasto e que o conhecimento dos mecanismos de ação das Nks pode pavimentar o caminho para o desenvolvimento de novas terapias antitumorais, voltadas especificamente para o controle da arquitetura tumoral.

Descritores: Antitumoral; Neoplasia; Resposta Inata. 


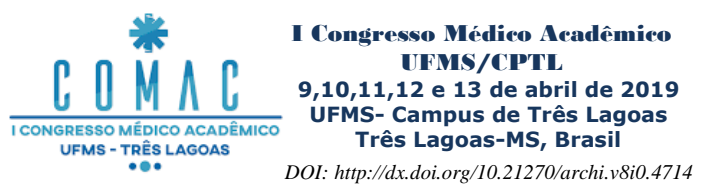

\section{PROJETO SAÚDE NA ESCOLA - EDUCAÇÃO SOBRE HPV}

Borges, S. B.; Domingues V. M.; Fé, V. V. M.; Vieira, A. M.; Fuentes, J. A.; Balderrama P. stella.bianchini.borges@gmail.com

Universidade Federal do Mato Grosso do Sul - Campus de Três Lagoas

Categoria: Pôster

Introdução: A falta de informações sobre o HPV pode interferir no comportamento das pessoas. A educação de adolescentes sobre os fatores de risco associados ao comportamento sexual, por meio de atividades educativas, é importante para o controle da transmissão. A escola deve contribuir com a educação em saúde de adolescentes e estimulá-los a utilizar o sistema público de saúde. Justificativa: Considerando-se a relevância epidemiológica do HPV e a existência de medidas profiláticas para sua prevenção e controle, esta atividade de educação em saúde justificou-se pela necessidade de orientar adolescentes sobre tais medidas.

Descrição das atividades realizadas: Trata-se de um relato de experiência de uma atividade de educação em saúde direcionada a alunos do $8^{\circ}$ ano do ensino fundamental II de uma escola estadual, realizada por estudantes do $6^{\circ}$ período do curso de medicina da UFMS/CPTL. A fase de preparação da atividade contou com uma etapa para planejamento e escolha do tema e outra para a execução da atividade. Primeiramente foi realizada uma reunião com o grupo do projeto, direção da escola e professora responsável. À partir do Guia de Sugestões de Atividades do Programa Saúde na Escola (PSE) do Ministério da Saúde e da Educação, foram selecionadas três dinâmicas adaptadas: um cartaz de erros e acertos, uma brincadeira de "batata-quente" e uma gincana com placas de verdadeiro ou falso. Os alunos participaram de maneira bastante interativa. Considerações finais: A atividade proporcionou aos acadêmicos de medicina uma vivência extremamente positiva em educação em saúde. O interesse e a participação dos alunos, alvos da ação, pode contribuir para a promoção de saúde desses indivíduos.

Descritores: Educação em Saúde; Papillomaviridae; Adolescentes. 


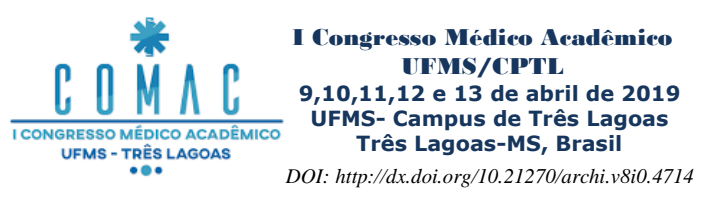

\section{RELAÇÃO DAS VARIANTES GENÉTICAS DO GENE MECP2 COM AS COMORBIDADES ENVOLVIDAS NA SÍNDROME DE RETT}

Ferreira, A.; Alencar, T.; Júnior, L.; Souza, L.; Valder, R.; Belini-Júnior, E. nanarmfuberaba@gmail.com

UFMS/CPTL - Universidade Federal de Mato Grosso do Sul, Campus de Três Lagoas

Categoria: Pôster

A Síndrome de Rett (SR) é uma desordem do desenvolvimento neurológico prevalente em mulheres e causada por mutações no gene $M E C P 2$. Pessoas com SR apresentam manifestações clínicas heterogêneas, fato que dificulta o diagnóstico clínico. A associação das mutações com as comorbidades da SR pode auxiliar no entendimento da relação genótipo-fenótipo. O objetivo do trabalho foi estabelecer associações das mutações no gene $M E C P 2$ com as comorbidades da SR e reunir informações úteis da genética e fenótipo da doença. Realizou-se uma busca nas bases de dados medline e lilacs com descritores: síndrome de Rett, MECP2 e genética, de 2009 a 2018. Dos 65 artigos encontrados, foram selecionados 15, que relacionavam as mutações gênicas com as comorbidades da SR. Há 4 estágios clínicos da SR. No estágio I, relata-se estagnação do desenvolvimento, crescimento lento do perímetro cefálico, associados a mutação $808 \mathrm{C}>\mathrm{T}$, e isolamento social. No estágio II, há regressão psicomotora, perda da fala adquirida, comportamento autista e demência severa com associação a mutação $455 \mathrm{C}>\mathrm{G}$. Ainda, há movimentos estereotipados das mãos associados a $502 \mathrm{C}>\mathrm{T}$ e $808 \mathrm{C}>\mathrm{T}$. No estágio III, vê-se ataxia, apraxia, espasticidade, perda de fôlego, aerofagia, expulsão forçada do ar e saliva. Além disso, as estereotipias, relacionadas com as mutações $763 \mathrm{C}>\mathrm{T}, 808 \mathrm{C}>\mathrm{T}$, e $502 \mathrm{C}>\mathrm{T}$, e as crises convulsivas, relacionadas com 916C > T, são características dessa fase. No estágio IV, há escoliose, relacionada à mutação $473 \mathrm{C}>\mathrm{T}$, e desvio cognitivo grave. A mutação $455 \mathrm{C}>\mathrm{G}$ é vista nesse estágio, associada a dificuldades oro-motoras. A associação das mutações no gene $M E C P 2$ com estágios e manifestações específicas da SR trouxe informações importantes acerca da etiologia da SR e de possíveis marcadores genéticos para diagnóstico e prognóstico da SR.

Descritores: Genética; Síndrome; Mutação. 


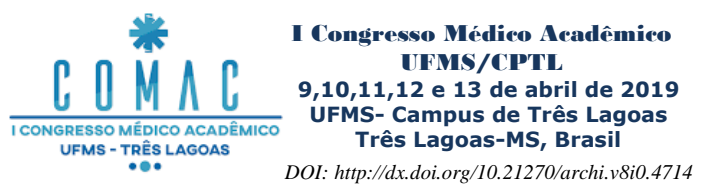

\author{
RELAÇÃO GENÓTIPO-FENÓTIPO E AVANÇOS TERAPÊUTICOS
FENILCETONÚRIA \\ Patuço, I. C.; Romanosque, J.L.M.; Machado, I.C.; Costa, M.S.; Pereira, P.R.; Júnior, E.B. \\ isabela.patuco@gmail.com \\ Universidade Federal de Mato Grosso do Sul - Campus de Três Lagoas \\ Categoria: Pôster
}

PARA

A

A Fenilcetonúria (PKU) é uma doença genética autossômica recessiva causada por mutações no gene da fenilalanina hidroxilase $(\mathrm{PAH})$, em que há deposição excessiva de fenilalanina nos líquidos corporais, acarretando danos neurológicos graves se não tratada precocemente. Diante do número de mutações presentes no gene PAH e a influência sobre o fenótipo da PKU, avaliou-se os avanços terapêuticos frente às relações genótipo-fenótipo e como respondem ao tratamento proposto. Foi realizada uma revisão integrativa nos bancos de dados Pubmed, Lilacs e Scielo com os descritores "fenilcetonúria", "mutação" e "terapia". De 20 artigos com pesquisas em humanos publicados nos últimos cinco anos selecionou-se 15. Destes destacaram-se as alterações na enzima PAH como 1066-11G >A, mais frequente na PKU clássica, a $1162 \mathrm{G}>\mathrm{A}$ e a $782 \mathrm{G}>\mathrm{A}$ na leve-moderada, ambas na Espanha; neste cenário a terapia com tetrahidrobiopterina (BH4) mostrou-se irresponsiva. Na Sérvia há uma mutação 676C>A na PKU grave e sem resposta para Sepiapterina. Na Itália a IVS10-11G>A é predominante na PKU clássica e a 870T >G é a recém descrita na PKU leve. Outra alteração genética é nos precursores de BH4, como o 6piruvoyltetrahidropterina sintase (PTPS) onde utilizou-se a associação de BH4, L-dopa e 5-HTP, porém as respostas terapêuticas variaram. Assim, têm-se visado o desenvolvimento de novas terapêuticas como chaperonas e tecnologias genômicas, dentre elas evidenciam-se as nucleases de dedo de zinco (ZFNs), os ativadores transcricionais como nucleases efetoras (TALENs) e as repetições palindrômicas curtas agrupadas e regularmente interespaçadas (CRISPR). Desse modo, conclui-se que há diferenças nas respostas terapêuticas devido às variações genotípicas-fenotípicas de cada paciente.

Descritores: Fenilcetonúria; Mutação; Terapia. 


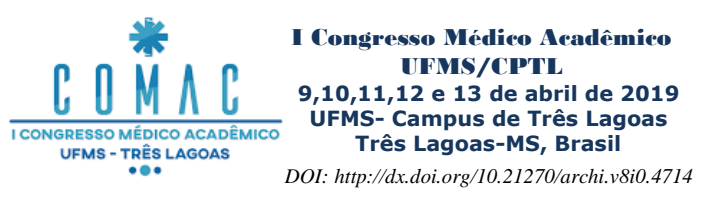

\section{RESULTADO PRELIMINAR DO EFEITO LARVICIDA DE EXTRATOS VEGETAIS DE CROTALARIA PALLIDA SOBRE O AEDES AEGYPTI}

Souza, T.G.B; Takagi, B.A.; Oliveria, M.D.; Bernardes, L.G.; Machado, A.R.S.R.; Machado, A.M.

alex.machado@ufms.br

Universidade Federal de Mato Grosso do Sul - Campus de Três Lagoas

Categoria: Pôster

A Dengue, dentre as doenças virais de transmissão vetorial, é a que possui maior impacto na morbidade e mortalidade da população mundial. O surgimento de resistência aos inseticidas tem causado dificuldades no controle do inseto vetor (Aedes aegypti) e estimulado à busca de vegetais com ação larvicida. A biodiversidade do cerrado é pobremente conhecida e o seu potencial de uso menos ainda. Algumas plantas desse bioma como a Crotalária pallida apesar de ser popularmente conhecida e usada como repelente, possui pouca comprovação científica. Assim, o objetivo deste trabalho foi utilizar esta planta para verificação de seu potencial antilarval em larvas de segundo instar de A. aegypti. Ovos do vetor foram eclodidos em água, sendo separados 15 larvas para cada teste com os extratos, sendo feitos em triplicata. Os vegetais foram submetidos aos processos de extração com solventes hexanos (Hx), acetato de etila (AcOEt), etanol $(\mathrm{EtOH})$ ou metanol $(\mathrm{MeOH})$, obtendo uma concentração final de $500 \mu \mathrm{g} / \mathrm{ml}$. A ação larvicida dos extratos forma determinadas após 24 horas do contato de cada extrato $(500 \mu \mathrm{g} / \mathrm{ml}) \mathrm{com}$ as larvas. Diluições da concentração inicial $(250 ; 125 ; 62,5 ; 31,25 \mu \mathrm{g} / \mathrm{ml})$ foram realizadas para determinação da dose letal (DL90 e DL50). O resultado mostrou que o extrato a base de AcOEt de C. pallida possui ação larvicida após 24 horas com morte de $100 \%$ das larvas na concentração de $500 \mu \mathrm{g} / \mathrm{ml}$. $\mathrm{O}$ extrato EtOH também mostrou alta eficiência na morte das larvas, com $88 \%$ de mortalidade na mesma concentração. As análises estatísticas mostraram significância entre a concentração do extrato, e a mortalidade das larvas. Apesar de tratar-se de um resultado promissor, novos estudos com outras partes da planta e em outros instars larvais, são necessários para o melhor entendimento da função antilarval desse produto.

Descritores: Controle Vetorial; Plantas Inseticidas; Bioinseticida. 


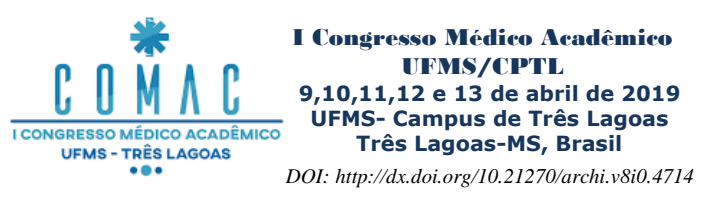

\section{REVELAÇÃO DA VERDADE EM PUBLICAÇÕES DE AUTORES BRASILEIROS: REVISÃO INTEGRATIVA DE LITERATURA}

Gonçalves, L. G. M.; Santos, A.T.; Brandão, G.B.; Lima, J.V.; Silva, T.A.; Pessalacia, J.D.R. tayrys.allyne@gmail.com

Universidade Federal de Mato Grosso do Sul - Campus de Três Lagoas

Categoria: Pôster

A Comunicação de más notícias é um exercício que exige do profissional de saúde conhecimento, técnica e empatia, a fim de amenizar o sofrimento causado pela notícia. $\mathrm{O}$ presente artigo tem como objetivo sintetizar e analisar as publicações de autores brasileiros sobre a comunicação de más notícias. A revisão integrativa foi utilizada com vistas a responder a questão norteadora: Como estudos nacionais abordam a comunicação de más notícias por profissionais da saúde? Foi realizada busca nas bases de dados MEDLINE, LILACS, IBECS, BDENF - Enfermagem, CUMED, Index Psicologia Periódicos técnicos científicos, WHOLIS, PAHO-IRIS, BINACS, Coleciona SUS e PAHO, a partir do descritor padronizado e disponível nos Descritores em Ciências da Saúde (DeCS), 'Revelação da verdade'. Foram selecionados artigos com textos completos, no espaço temporal compreendido entre 2013 a 2017 e escritos em português. Para análise dos artigos, buscou-se os núcleos de sentido que compõe o corpus de 9 artigos selecionados. A partir das buscas, encontrou-se diversas pesquisas e temas relacionados a comunicação entre pacientes oncológicos, portadores de HIV e a equipe médica que foram subdivididas em três categorias: Dificuldades enfrentadas pelos profissionais da saúde na revelação de más notícias para os pacientes e seus familiares; Experiências vivenciadas pelos pacientes e seus familiares diante da revelação de más notícias; Visão dos pacientes e seus familiares sobre os aspectos comunicacionais de más notícias pelos profissionais da saúde. Depreendeu-se que a comunicação é um processo que envolve diversos fatores e pessoas, tornando o processo dificultoso e que necessita-se refletir a respeito do assunto.

Descritores: Revelação da Verdade; Comunicação; Profissionais; Pacientes. 


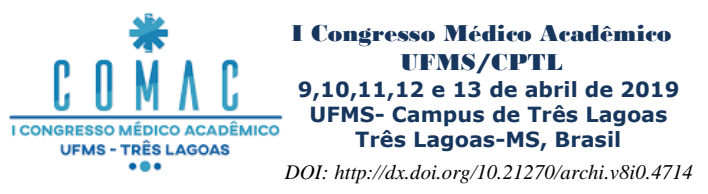

\section{SAÚDE AO ALCANCE DAS MÃOS: UMA REVISÃO SISTEMÁTICA DA APLICABILIDADE DE SMARTWATCHES E SMARTBANDS NA QUALIDADE DE VIDA E ASSISTÊNCIA À SAÚDE}

Silva, M.V.A.; Scalon, J.M.C.; Corazza, A.V.

marcus.azevedo@live.com

Universidade Federal do Mato Grosso do Sul - Campus de Três Lagoas

Categoria: Pôster

Pulseiras e relógios inteligentes são atualmente tecnologias emergentes. Seu uso como rastreadores de condicionamento físico e dispositivos de sensores corporais não invasivos pode ter amplo impacto nos sistemas de saúde e na qualidade de vida devido à sua grande promessa para uma infinidade de aplicações. Diante da popularização desses dispositivos e a quantidade de informações disponíveis sobre tal temática, o presente estudo visa identificar e analisar trabalhos que abordem o uso de tecnologias eletrônicas vestíveis de punho na perspectiva da assistência à saúde, monitoramento de patologias e qualidade de vida. Trata-se de uma revisão integrativa com vistas a responder à questão norteadora: quais os benefícios e potencialidades do uso de tecnologias vestíveis de punho na saúde? Foi realizada a busca de artigos nas bases de dados da Biblioteca Virtual em Saúde (BVS) e da Biblioteca Nacional de Medicina dos Estados Unidos (PUBMED), empregando os termos "Health" AND "Smartband" OR "Smartwatch", em todos os idiomas e com texto completo disponível. De 2015 a 2019, identificou-se 64 artigos e, em uma rápida leitura, 27 atendiam à proposta. As evidências demonstram que a aplicação desses dispositivos é possível em diferentes domínios: monitoramento de atividades físicas; frequência e ritmo cardíaco; reconhecimento do ato de fumar; detecção de quedas; e manejo de doenças crônicas, tais como diabetes, esclerose múltipla, asma, autismo, osteoartrose, Parkinson, AVC e DPOC. Com informações em tempo real, esses aparelhos permitem que os indivíduos mudem seu estilo de vida, otimizem exercícios ou treinamentos, previnam lesões e detectem precocemente sinais de doenças ou distúrbios, auxiliando, dessa maneira, a tomada de ações preventivas para evitar a deterioração de um problema de saúde e, assim, diminuindo gastos e melhorando prognósticos.

Descritores: Dispositivos Eletrônicos Vestíveis; Assistência à Saúde; Qualidade de Vida. 


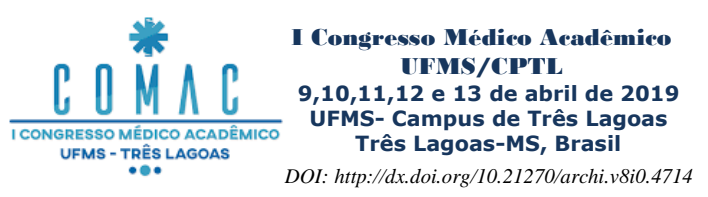

\author{
SINTOMAS DEPRESSIVOS EM ADULTOS E IDOSOS CADASTRADOS NA ESTRATÉGIA \\ SAÚDE DA FAMÍLIA \\ Augusto, A.C.S; Silva, L.A.; Ribeiro, A.M.F.; Carrijo, M.F.; Luchesi, B.M.; Martins, T.C.R. \\ anacristinaufms@gmail.com \\ Universidade Federal de Mato Grosso do Sul - Campus de Três Lagoas \\ Categoria: Pôster
}

Os transtornos mentais atingem cerca de 350 milhões de pessoas no mundo e representam 7,4\% dos anos de vida ajustados por incapacidades. O transtorno mais frequente é a depressão que, no Brasil, tem prevalência de $18,4 \%$. Os sintomas depressivos contribuem para a diminuição da capacidade funcional e da qualidade de vida em adultos e idosos. Trata-se de uma enfermidade multifatorial e um importante fator de risco para outras doenças. $\mathrm{O}$ objetivo deste trabalho foi estimar a prevalência de sintomas depressivos em adultos e idosos cadastrados na Estratégia Saúde da Família (ESF) do município de Três Lagoas/MS. Trata-se de um estudo transversal e quantitativo, realizado no período de 2018/2019, em 99 indivíduos com idade $\geq 45$ anos, de ambos os sexos, cadastrados nas ESF de Três Lagoas-MS. O instrumento de coleta de dados utilizado foi um questionário estruturado. A sintomatologia depressiva foi avaliada por meio da escala Center for Epidemiological-Studies-Depression (CES-D). O tratamento dos dados foi feito por meio da estatística descritiva. Sobre os participantes, a maioria eram mulheres $(62,6 \%)$, com idade $\geq 60$ anos (52,5\%), que possuíam de 5-8 anos de escolaridade (32,3\%) e renda entre 1 a 3 salários mínimos (53,5\%). A prevalência de sintomas depressivos foi de 64,4\%. Apresentaram sintomas depressivos, $74,2 \%$ das mulheres e 48,6\% dos homens. Houve uma maior proporção de sintomatologia depressiva entre os indivíduos com idade entre 45-59 anos $(70,2 \%)$, obesos $(68,6 \%)$, com menor escolaridade $(71,1 \%)$ e menor renda $(70,6 \%)$. Os dados evidenciam maior proporção de sintomas depressivos em uma parcela mais vulnerável da população: mulheres, pessoas obesas, com baixa renda e escolaridade. Assim, como forma de enfrentamento desse problema de saúde pública, percebe-se a necessidade de formular estratégias de prevenção e promoção de saúde voltadas para esses grupos.

Descritores: Saúde Mental; Depressão; Atenção Primária à Saúde.

Apoio: Bolsa de iniciação científica UFMS (Edital PROPP/UFMS 095/2018) 


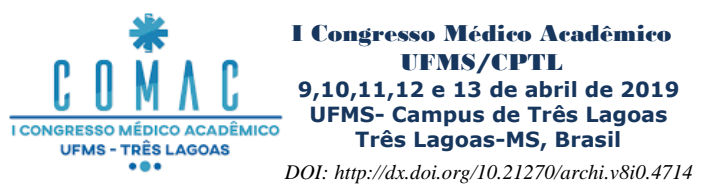

\section{SINTOMAS DEPRESSIVOS EM PACIENTES COM CÂNCER DE MAMA EM TRATAMENTOS ANTINEOPLÁSICOS: UMA REVISÃO BIBLIOGRÁFICA}

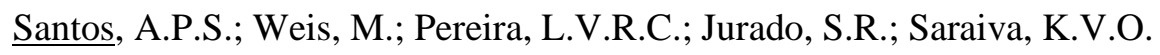

eng.anapaulasantos@gmail.com

Universidade Federal de Mato Grosso do Sul - Campus de Três Lagoas

Categoria: Pôster

O câncer de mama é o segundo tipo de câncer mais frequente no mundo e o mais frequente na população feminina brasileira. $\mathrm{O}$ diagnóstico e tratamento do câncer são experiências altamente estressantes para a maioria dos pacientes. Os tratamentos, como quimioterapia, radioterapia e cirurgia são muito agressivos e, isso pode levar ao aparecimento de sintomas como dor, fadiga, distúrbio do sono, ansiedade e depressão. O objetivo desse trabalho foi identificar na literatura a ocorrência de depressão em mulheres com câncer de mama, submetidas ao tratamento quimioterápico e radioterápico. Tratou-se de uma revisão integrativa, utilizando os descritores: câncer de mama e depressão. Foram realizadas buscas nas bases de dados LILACS, SciELO e Pubmed, referente ao período de 2005 a 2018. A pergunta norteadora foi: Quais as chances da mulher com câncer de mama desenvolver depressão durante tratamento quimioterápico e radioterápico? Um total de vinte e dois artigos foi incluído nesse estudo. Os sintomas depressivos foram comuns em mulheres com câncer de mama e submetidas aos tratamentos quimioterápicos e radioterápicos, variando de $51,5 \%$ a $95 \%$. A prevalência de depressão maior variou de $1,78 \%$ a $12,40 \%$, na literatura estudada. Os sintomas depressivos foram significativamente mais frequentes nas mulheres que relataram presença de dor e esperança diminuída. A depressão interferiu negativamente na adesão ao tratamento e na qualidade de vida dessas pacientes. Algumas técnicas de intervenção, como relaxamento por imagem guiada, meditação e ioga, podem auxiliar na diminuição do estresse e da depressão em pacientes com câncer de mama. O paciente oncológico precisa de apoio emocional prestado por equipe multiprofissional, contribuindo para reduzir as complicações cognitivas, afetivas e comportamentais decorrentes do diagnóstico e tratamento.

Descritores: Câncer de Mama; Depressão; Radioterapia. 


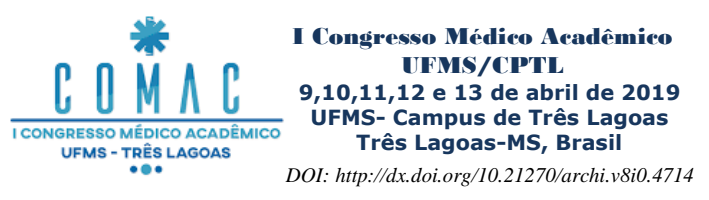

\section{TRATAMENTO DE OSTEOARTROSE DE JOELHO UTILIZANDO PLASMA RICO EM PLAQUETAS(PRP) - REVISÃO DE UMA NOVA LINHA DE TRATAMENTO}

Cintra, G.S.; Xavier, A.C.; Batista, R; Corazza, A.V.

gabriel1097@hotmail.com

Universidade Federal de Mato Grosso do Sul - Campus de Três Lagoas

Categoria: Pôster

A osteoartrite (OA) do joelho é caracterizada por desgaste gradual da cartilagem articular, esclerose óssea subcondral e inflamação articular. Ainda não há cura e seu tratamento tem se concentrado na redução álgica e na manutenção ou melhora da mobilidade das articulações. Em pacientes com OA o plasma rico em plaquetas (PRP) tem apresentado aplicabilidade clínica nos últimos anos. O presente estudo realizou uma revisão sistemática para analisar a eficiência terapêutica do PRP na OA de joelho. Utilizou-se como bases de dados: PUBMED/MEDLINE, e os seguintes descritores: Osteoarthritis, Knee, Platelet Rich Plasma. Apenas artigos em inglês e estudos clínicos dos últimos 5 anos foram selecionados. Após ler 29 artigos, selecionou-se 21 para a composição deste estudo. Desses, 19\% apresentaram o PRP mais eficaz e 14,2\% com eficácia igual ao ácido hialurônico (HA); 38\% trouxeram a aplicação do PRP sem grupo controle; 4,8\% mostraram o PRP mais eficaz que o Plasma Rico em Leucócitos (PRL); 4,8\% trouxeram o PRP com eficácia igual ao placebo; 9,5\% compararam o tempo de administração de PRP a eficácia e 9,5\% afirmaram que o PRP é melhor que tratamentos convencionais. Além disso, observou-se que não há um padrão de aplicação e nem de coleta do PRP, ficando a critério dos organizadores do estudo, bem como o tempo e a forma de aplicação. Apesar de o PRP funcionar melhor com OA leve, os estudos científicos controlados são limitados. Neste sentido, sugere-se que o PRP apresenta resultados positivos, quando comparado aos demais métodos, sendo, portanto, uma boa alternativa para reduzir a dor e melhorar a mobilidade e incapacidade dos pacientes, sem ter que recorrer a métodos cirúrgicos. Entretanto há a necessidade de estudos padronizados no preparo do PRP e comparados a grupos placebos para fidelizar a terapêutica da OA de joelho

Descritores: Osteoartrite; Joelho; Plasma Rico em Plaquetas. 


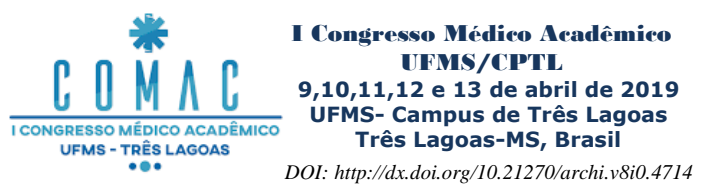

\section{UP TO DATE SOBRE O USO DO LASER DE BAIXA POTÊNCIA PARA TRATAMENTO DA INFERTILIDADE FEMININA}

Da Silva, G.D.; Jurado, S.R. genesisdonizete@gmail.com Universidade Federal de Mato Grosso do Sul - Campus de Três Lagoas

Categoria: Pôster

A infertilidade foi considerada pela Organização Mundial de Saúde como um importante problema de saúde pública. As principais causas da infertilidade feminina são disfunções na ovulação, alterações nas tubas uterinas e útero. O laser de baixa potência (LBP) tem sido utilizado para o tratamento da infertilidade. O objetivo deste estudo foi avaliar os efeitos do LBP nos casos de infertilidade feminina. Trata-se de uma revisão integrativa, realizada na base de dados PubMed, no período de 2007 a 2018 , utilizando os descritores em inglês: laser (laser) e female infertility (infertilidade feminina). Como critérios de inclusão dos artigos científicos, destacaram-se: possuir dois descritores no título ou resumo, escritos na língua inglesa, pesquisas experimentais, incluindo humanos e outros animais. Foram excluídos artigos escritos em outros idiomas, editoriais e revisões bibliográficas. A partir da busca na PubMed foram localizados 135 trabalhos, contudo, selecionados apenas 4 artigos e, a partir da leitura desses, selecionados mais 3 trabalhos. Portanto, a amostra final foi composta por 7 artigos científicos. $\mathrm{O}$ laser de baixa potência, no espectro do infravermelho $(810-830 \mathrm{~nm})$, foi capaz de estimular foliculogênese em ratas e a proliferação de células endometriais, ovulação, aumento do fluxo sanguíneo ovariano e uterino bem como gravidezes bem-sucedidas em mulheres com infertilidade, por concepção de forma natural ou fertilização in vitro. Ademais, destaca-se a Teoria da Prioridade Proximal, encontrada em $71 \%$ dos artigos pesquisados, a qual consiste da aplicação do laser infravermelho, na região das artérias carótidas, indicada para tratamento da infertilidade. Portanto, o uso do laser de baixa potência é uma técnica muito promissora, de baixo custo, não invasiva e que não apresenta efeitos colaterais para o tratamento da infertilidade feminina.

Descritores: Terapia a Laser; Infertilidade; Ovócitos. 